\title{
A User's Guide for the BNW-III Optimization Code for Modular Dry/Wet-Cooled Power Plants
}

David J. Braun

Duane W. Faletti

September 1984

Prepared for the U.S. Department of Energy under Contract DE-AC06-76RLO 1830

Pacific Northwest Laboratory Operated for the U.S. Department of Energy by Battelle Memorial Institute 


\title{
DISCLAIMER
}

This report was prepared as an account of work sponsored by an agency of the United States Government. Neither the United States Government nor any agency thereof, nor any of their employees, makes any warranty, express or implied, or assumes any legal liability or responsibility for the accuracy, completeness, or usefulness of any information, apparatus, product, or process disclosed, or represents that its use would not infringe privately owned rights. Reference herein to any specific commercial product, process, or service by trade name, trademark, manufacturer, or otherwise, does not necessarily constitute or imply its endorsement, recommeridation, or favoring by the United States Government or any agency thereof. The views and opinions of authors expressed herein do not necessarily state cr reflect those of the United States Government or any agency thereof.

\author{
PACIFIC NORTHWEST I.ABORATORY \\ operated by \\ BATTELLE \\ for the \\ UNITED STATES DEPARTMENT OF ENERGY \\ under Contract DE-AC06-76RLO 1830
}

\begin{tabular}{|c|c|}
\hline \multicolumn{2}{|c|}{ Printed in the United States of America } \\
\hline \multirow{2}{*}{\multicolumn{2}{|c|}{$\begin{array}{c}\text { Available from } \\
\text { National Technical Information Service }\end{array}$}} \\
\hline & \\
\hline \multicolumn{2}{|c|}{ United States Department of Commerce } \\
\hline \multicolumn{2}{|c|}{5285 Port Roval Road } \\
\hline \multicolumn{2}{|c|}{ Springfield, Virginia 22151} \\
\hline \multirow{2}{*}{\multicolumn{2}{|c|}{$\begin{array}{l}\text { NTIS Price Codes } \\
\text { Microfiche A01 }\end{array}$}} \\
\hline & \\
\hline \multicolumn{2}{|c|}{ Printed Copy } \\
\hline & Price \\
\hline Pages & Codes \\
\hline $001-025$ & $\mathrm{~A} 02$ \\
\hline 026-050 & $\mathrm{A} 03$ \\
\hline $051-075$ & A04 \\
\hline $076-100$ & A05 \\
\hline $101-125$ & A06 \\
\hline $126-150$ & A07 \\
\hline $151-175$ & $\mathrm{~A} 08$ \\
\hline $176-200$ & A09 \\
\hline $201-225$ & A010 \\
\hline $226-250$ & A011 \\
\hline $251-275$ & A012 \\
\hline 276-300 & A013 \\
\hline
\end{tabular}


A USER'S GUIDE FOR THE BNW-III OPTIMIZATION CODE FOR MODULAR DRY/WET-COOLED POWER PLANTS

David J. Braun

Duane W. Faletti

September 1984

Prepared for the U.S. Department of Energy under Contract DE-AC06-76RLO 1830

Pacific Northwest Laboratory

Richland, Washington 99352 
FOREWORD

The Dry Cooling Enhancement project has been a Pacific Northwest Laboratory (PNL) activity for about six years, at an an approximate professional staff level of 12 man-years/year. The objectives of the project are to develop, in conjunction with utilities in the cooling tower industry, dry cooling systems and dry/wet cooling systems that conserve scarce water resources and increase power plant siting flexibility with a minimum increase in the cost of generating electricity. The thrust of the project has included the following initial and ultimate objectives.

Initial Objectives

- Develop economic and performance models for cost optimization of total heat rejection systems using dry and dry/wet cooling.

- Analyze and disseminate operating experience on existing dry-cooled plant performance.

- Demonstrate certain features of existing technology equipment to provide confidence for specification by utilities.

Ultimate Objective

- Promote water conservation through industry use of dry cooling by developing and demonstrating the reliability of lower cost systems. The development of advanced dry/wet systems is also considered to be within this scope.

The depth and extent of this project can perhaps best be presented through a listing of the documents which have been issued by the staff involved in this project. Unless otherwise specified, these documents were prepared by the Pacific Northwest Laboratory, Richland, Washington. The Pacific Northwest Laboratory is operated by Battelle Memorial Institute for the U.S. Department of Energy. 
Six documents have been written on the analysis of performance of existing dry-cooled plants and air-cooled heat exchanger equipment:

1. Dry Cooling Tower Project: Results of Industrial Contacts Through August 1972. BNWL-1878, November 1, 1974.

2. A Survey of Materials and Corrosion Performance in Dry Cooling Applications. A. B. Johnson, Jr., D. R. Pratt and G. E. Zima, BNWL-1948, March 1976.

3. European Dry Cooling Tower Operating Experience. J. G. DeSteese and K. Simhan, BNWL-1995, March 1976.

4. Mathematical and Experimental Investigations on Dispersion and Recirculation of Plumes from Dry Cooling Towers at WYODAK Power Plant in Wyoming. Y. Onishi and D. S. Trent, BNWL-1982, February 1976.

5. Aluminum Alloy Performance Under Dry Cooling Tower Conditions. A. B. Johnson, Jr., S. Begaj, M. W. Martini, and R. P. May, PNL-02392, December 1977.

6. Aluminum Alloy Performance in Industrial Air-Cooled Applications. K. R. Wheeter, A. B. Johnson, Jr., and R. P. May, PNL-SA-8103, April 1980.

Five documents have addressed advanced dry/wet-cooled systems.

1. Preliminary Evaluation of Wet/Dry Cooling Concepts for Power Plants. W. V. Loscutoff, BNWL-1969.

2. Compatibility of Ammonia with Candidate Dry Cooling System Materials. D. R. Pratt, BNWL-1992, April 1976.

3. Scale Formation in Deluged Dry Cooling Systems. D. R. Pratt, BNWL-2070, March 1976.

4. Ammonia as an Intermediate Heat Exchange Fluid for Dry-Cooled Towers. R. T. Allemann, B. M. Johnson and G. C. Smith, BNWL-SA-5997, September 1976.

5. Cost Analysis of an Ammonia Dry Cooling System with Chicago Bridge and Iron Peak Shaving System. M. K. Drost and B. M. Johnson, PNL-3272, November 1980.

Three reports have been issued which consider the future need for any cooling and the potential benefit/cost ratio for a large-scale demonstration. 
1. An Overview of Economic, Legal and Water Availability Factors Affecting the Demand for Dry and Wet/Dry Cooling of Thermal Power Plants.

P. L. Hendrickson, BNWL-2268, September 1978.

2. Estimation of Benefits from Demonstrating Advanced Dry Cooling Technology: A Framework and Partial Analysis. J. W. Currie and J. T. Foley, BNWL-2182, April 1977.

3. Potential Use of Dry Cooling in Support of Advanced Energy Generation Systems. D. W. Mayer, E. M. Arnold and R. T. Allemann, PNL-3149, September 1979.

Cost optimization of dry-cooled and dry-heat-cooled rejection systems has been extensively studied in three reports.

1. A Review and Assessment of Engineering Economic Studies of Dry-Cooled Electrical Generating Plants. B. C. Fryer, BNWL-1976, March 1976.

2. Heat Transfer and Pressure Drop Characteristics of Dry Tower Extended Surfaces. Part I: Heat Transfer and Pressure Drop Data. Prepared for the Pacific Northwest Laboratory by PFR Engineering Systems, Incorporated, PFR 7-100, March 1976.

3. Heat Transfer and Pressure Drop Characteristics of Dry Tower Extended Surfaces. Part II: Data Analys is and Correlations. Prepared for the Pacific Northwest Laboratory by PFR Engineering Systems, Incorporated, PFR 7-102, June 1976.

The Pacific Northwest Laboratory has issued a group of reports, including this one, that: 1) develop cost optimization models for dry cooling systems based on available technology; and 2) compare the cost analysis of three systems with the projected cost of several advanced dry and dry/wet systems. Included in this group of reports are:

1. Dry Cooling of Power Generating Stations: A Summary of the Economic Evaluation of Several Advanced Concepts via a Design Optimization Study and a Conceptual Design and Cost Estimate. B. M. Johnson, R. T. Allemann, D.W. Falletti, B. C. Fryer, and F. R. Zaloudek, BNWL-2120, September 1976.

2. An Engineering and Cost Comparison of Three Different All-Dry Cooling Systems. B. C. Fryer, D. W. Faletti, Daniel J. Braun, David J. Braun, and L. E. Wiles, BNWL-2121, September 1976.

3. A Study of the Comparative Costs of Five Wet/Dry Cooling Tower Concepts. F. R. Zaloudek, R. T. Allemann, D. W. Faletti, B. M. Johnson, H. L. Parry, G. C. Smith, R. D. Tokarz, and R. A. Walter, BNWL-2122, September 1976. 
4. Costs and Cost Algorithms for Dry Cooling Tower Systems. P. A. Ard, C. H. Henager, D. R. Pratt, and L. E. Wiles, BNWL-2123, September 1976.

5. A User's Manual for the BNW-I Optimization Code for Dry-Cooled Power Plants. David J. Braun, Daniel J. Braun, W. V. DeMier, D. W. Faletti, and L. E. Wiles, BNWL-2180, January 1977.

6. Comparative Cost Study of Four Wet/Dry Cooling Concepts That Use Ammonia as the Intermediate Heat Exchange Fluid. Daniel J. Braun, R. D. Tokarz, B. M. Johnson, R. T. Allemann, David J. Braun, D. W. Faletti, L. J. MacGowan, H. L. Parry, G. C. Smith, and F. R. Zaloudek, PNL-2661, May 1978.

7. An Engineering and Cost Analysis of a Dry Cooling System Augmented with a Thermal Storage Pond. M. K. Drost and R. T. Allemann, PNL-2745, September 1978.

8. A User's Manual for the BNW-I I Optimization Code for Dry/Wet Cooled Power Plants. Daniel J. Braun, J. A. Bamberger, David J. Braun, D. W. Faletti, and L. E. Wiles, PNL-2674, Vol. 1, May 1978.

9. A Description and Cost Analysis of a Deluge Dry/wet Cooling System. L. E. Wiles et al., PNL-2498, June 1978 .

10. A User's Guide for the BNW-III Optimization Code for Modular Dry/WetCooled Power Plants. D. J. Braun and D. W. Faletti PNL-4506, October 1982.

The primary focus of the dry cooling project has been to carry out a large-scale test of the system in the Advanced Concepts Test (ACT) facility built at the Kern Plant of Pacific Gas and Electric of Bakersfield, California.

The Pacific Northwest Laboratory performed the conceptual design study and cost estimates of the proposed test facility with assistance from an architectengineering firm, and has managed the subsequent design and construction by the C. F. Braun Company of Alhambra, California. Documents which have been issued on the ACT facility design and the testing project include:

1. Advanced Concepts Facility--Measurements and Suggested Test Plan. F. R. Zaloudek, L. J. Brown and R. T. Allemann. Prepared for the Electric Power Research Institute by Battelle, Pacific Northwest Laboratories, Richland, Washington. Research Project RP422-3. EPRI-CS-1530, September 1980. 
2. Development of an Advanced Concept Dry/wet Cooling of Power Generating Plants. B. M. Johnson, ed. Prepared for the Electric Power Research Institute by Battelle, Pacific Northwest Laboratories, Richland, Washington. Research Project RP422-3. EPRI-CS-1668, February 1981.

One of the methods of dry/wet cooling under test at the ACT facility is deluge cooling. In order to study the feasibility and performance characteristics of deluge cooling, PNL has constructed a small-scale air heat transfer facility. This facility is unique because its flexibility allows a combined heat and mass transfer phenomena to be studied in a variety of configurations. Studies of "limits" of water chemistry to avoid corrosion and deposition are being carried on in conjunction with these heat transfer studies in separate facilities. Reports of this work include:

1. Analysis and Experimental Results from the Pacific Northwest Laboratory Augmented Dry Cooling Surface Test Project. H. L. Parry, L. J. MacGowan, D. K. Kreid, and B. M. Johnson. PNL-2746, November 1978.

2. Dry/Wet Performance of a Plate-Fin Air-Cooled Heat Exchanger with Continuous Corregated Fins. S. G. Hauser, D. K. Kreid and B. M. Johnson. PNL-3428, February 1981.

3. Experimental Evaluation of a Dry/Wet Air-Cooled Heat Exchanger with Helically Wound Tubes. S. G. Hauser, R. L. Gruel, J. C. Huenefeld, E. J. Eschbach, B. M. Johnson and D. K. Kreid. PNL-4043, July 1982.

4. Deposition and Corrosion Phenomena on Aluminum Surfaces Under Deluged Dry Cooling Tower Conditions. K. R. Wheeler, R. P. May, J. G. Douglas, and J. H. Tylczak. Prepared for the Electric Power Research Institute by Battelle, Pacific Northwest Laboratories, Richland, Washington. EPRI-CS-1926, July 1981.

Finally, the application of dry and dry/wet cooling to other energyrelated situations has been treated in these documents:

1. Potential Use of Dry Cooling in Support of Advanced Energy Generation Systems. D. W. Mayer, E. M. Arnold and R. T. All emann. PNL-3149, September 1979.

2. Cost Analysis of an Ammonia Dry Cooling System with a Chicago Bridge and Iron Peak Shaving System. M. K. Drost and B. M. Johnson. PNL-3272, December 1980.

3. Cost Benefits from Applying Advanced Heat Rejection Concepts to a Wet/Dry Cooled Binary Geothermal Plant. D. W. Faletti. PNL-3419, March 1981. 


\section{ACKNOWLEDGMENTS}

This report contains an account of work sponsored by the Advanced Nuclear Systems and Projects (ANSP) Division of the U.S. Department of Energy in the Dry Cooling Enhancement Program at the Pacific Northwest Laboratory (PNL). The project was completed under the direction of R. $01 \mathrm{ds}$, ANSP Project Officer; and B. M. Johnson, Program Manager of the Dry Cooling Tower Enhancement Program at PNL. 
This user's guide describes BNW-III, a computer code developed by the Pacific Northwest Laboratory (PNL) as part of the Dry Cooling Enhancement Program sponsored by the U.S. Department of Energy (DOE). The BNW-III code models a modular dry/wet cooling system for a nuclear or fossil fuel power plant. The purpose of this guide is to give the code user a brief description of what the BNW-III code is and how to use it. It describes the cooling system being modeled and the various models used. A detailed description of code input and code output is also included.

The BNW-III code was developed to analyze a specific cooling system layout. However, there is a large degree of freedom in the type of cooling modules that can be selected and in the performance of those modules. The costs of the modules are input to the code, giving the user a great deal of flexibility.

The BNW-III code is the third type of computer code developed by PNL for use in the comparison of costs associated with advanced cooling systems. The relationships among the three types are as follows:

- all-dry cooling systems - the BNW-I type of code

- deluged dry-wet cooling systems - the BNW-II type of code

- modular dry-wet cooling systems - the BNW-III type of code.

These codes have been developed along the same lines to allow for comparisons among the three different systems being studied.

This user's guide

- overviews the cooling system and describes its modeled components

- discusses the code modeling rationale, including a utility model, the operating strategy of the cooling system, and plant scaling

- describes the primary BNW-III subroutines and their functions 
- outlines the scope and limitations of the optimization code, and details sample input and output

- presents a sample parametric study to illustrate what BNW-III can do and how the input must be prepared. 
ACKNOWLEDGMENTS

SUMMARY

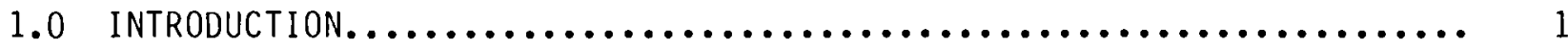

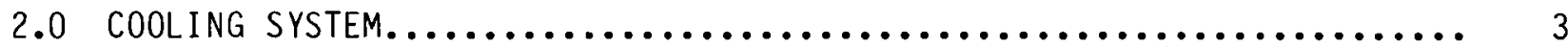

2.1 OVERVIEW....................................... 3

2.2 COOLING SYSTEM FEATURES......................... 6

2.2.1 Surface Condenser............................. 6

2.2 .2 Piping System................................ 6

2.2.3 Cooling Towers................................ 8

3.0 COOLING SYSTEM OPTIMIZATION RATIONALE $\ldots \ldots \ldots \ldots \ldots \ldots \ldots \ldots \ldots \ldots \ldots$

3.1 UTILITY MODEL $\ldots \ldots \ldots \ldots \ldots \ldots \ldots \ldots \ldots \ldots \ldots \ldots \ldots \ldots \ldots \ldots \ldots \ldots \ldots$

3.2 OPERATING STRATEGY OF COOLING SYSTEM.................. 10

3.2.1 Back Pressure Limitations....................... 10

3.2.2 All-Dry Module Operation....................... 11

3.2.3 Wet and Dry Module Operation..................... 12

3.3 STEAM SUPPLY AND PLANT SCALING..................... 13

4.0 DESCRIPTION OF BNW-III SUBROUTINES $\ldots \ldots \ldots \ldots \ldots \ldots \ldots \ldots \ldots \ldots \ldots \ldots \ldots$

4.1 DESIGN AND COSTING OF THE COOLING SYSTEM (SUBROUTINE CALC)..... 20

4.2 DESIGN FOR THE DRY MODULES (SUBROUTINE DRYDES) $\ldots \ldots \ldots \ldots \ldots \ldots$

4.3 DESIGN OF WET MODULES: CONSUMPTION OF WATER AVAILABLE....... 23

4.4 DESIGN OF PIPING SYSTEM (SUBROUTINE PIPDES) $\ldots \ldots \ldots \ldots \ldots \ldots \ldots$

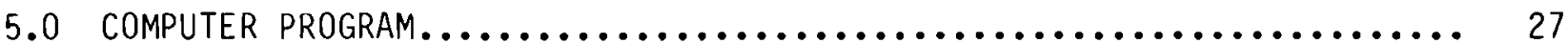

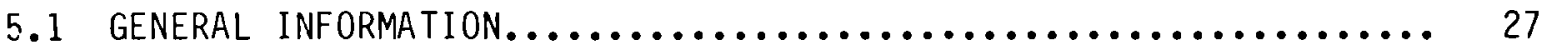

5.2 MODULAR DRY/WET CODE INPUT $\ldots \ldots \ldots \ldots \ldots \ldots \ldots \ldots \ldots \ldots \ldots \ldots \ldots \ldots \ldots \ldots \ldots \ldots$ 
5.3 MODULAR DRY/WET CODE OUTPUT...................... 43

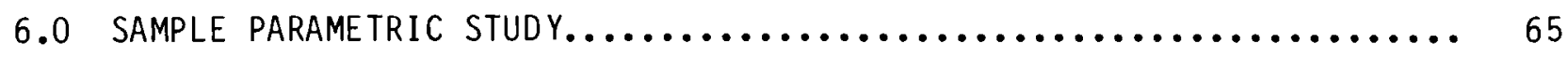

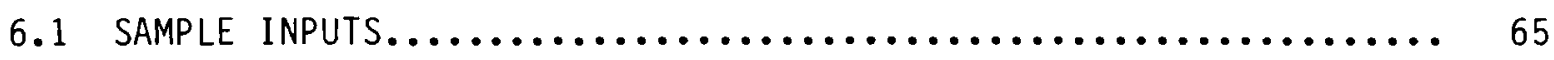

6.2 SAMPLE RESULTS............................... 70

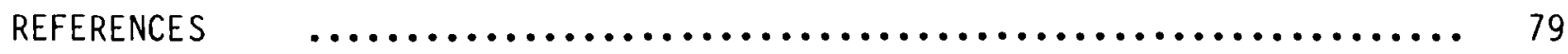

APPENDIX - DRY MODULE DESIGN CRITERIA...................... A.1 


\section{FIGURES}

1. Dry/Wet Modular Cooling System.............................. 4

2. Temperature Relationships Between Steam, Water, and Air in the Heat Rejection Cycle................................... 5

3. Piping Schematic $. \ldots \ldots \ldots \ldots \ldots \ldots \ldots \ldots \ldots \ldots \ldots \ldots \ldots \ldots \ldots \ldots, 7$

4. Operating Regimes for a Dry/Wet Modular Cooled Power Plant......... 11

5. Heat Rate Versus Back Pressure Fossil Tarbines................... 14

6. Typical Annual Performance of a Dry/Wet Modular Cooled Power Plant............................................... 14

7. Fl ow Diagram of BNW-III $\ldots \ldots \ldots \ldots \ldots \ldots \ldots \ldots \ldots \ldots \ldots \ldots, 18$

8. BNW-III Subroutine Linkage Chart......................... 30

9. Dry/Wet Modular Code Sample Input......................... 31

10. Dry/Wet Modular Code Sample Output......................... 49 


\section{TABLES}

1. Subroutines Containing Constraint-Imposing Variables............. 29

2. Design Basis Parameters................................ 66

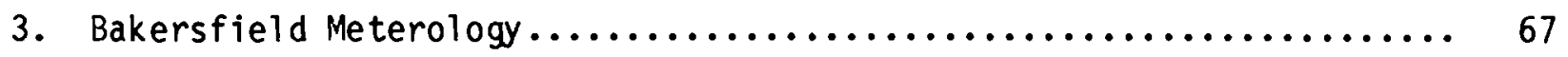

4. Dry Module Characteristics............................. 68

5. Wet Module Characteristics............................. 69

6. Optimum Designs at Different Water Availabilities............... 72

7. Effect of Fixing Design Inputs at 1200 acre-ft................ 74

8. Effect of a Minor Input Change on Local Optimums................ 76 


\subsection{INTRODUCTION}

The use of dry cooling for large base-load power plants has generally been precluded in the U.S. because of the inherent high costs. However, the need to conserve both the quantity and quality of remaining water resources is becoming increasingly important. The use of combined dry/wet cooling systems offers the potential for significant water savings in comparison to evaporatively cooled power plants, and significant cost savings in comparison to dry-cooled power plants. As part of the Dry Cooling Enhancement Program sponsored by the U.S. Department of Energy (DOE), the Pacific Northwest Laboratory (PNL) has deve1oped a computer code for optimizing the design of a modular dry/wet cooling system. This user's guide describes this design optimization code -- BNW-III -- and its use. By using BNW-III, a designer can compare the costs associated with different types of cooling modules within a specific cooling system layout. This guide also describes the results of an engineering optimization study of one type of dry/wet cooling system.

Two earlier design optimization codes had been developed as part of the Dry Cooling Enhancement Program. One code -- BNW-I -- (and its several modifications) is intended to provide an optimum configuration for several different types of all-dry power plant cooling systems (Braun et a1. 1977). The second code -- BNW-II -- (and modifications) optimized the configuration for two different arrangements of dry/wet "deluged" finned-tube heat exchanagers in which water for enhanced cooling is allowed to flow in a thin flim over the finned heat exchanger tubes (Braun et al. 1978). BNW-III, the code described in this guide, analyzes a dry/wet cooling system composed of separate all-dry and all-wet (evaporative) cooling modules functioning in series. The configuration considered is independent towers, but the methodology could be easily adapted to integrated modules of all-dry and evaporative cooling.

This user's guide is organized as follows:

- Section 2 overviews the cooling system and describes its modeled components. 
- Section 3 discusses the code modeling rationale, including a utility model, the operating strategy of the cooling system, and plant scaling.

- Section 4 describes the primary BNW-III subroutines and their functions.

- Section 5 outlines the scope and limitations of the optimization code, and details a sample input and output.

- Section 6 presents a sample parametric study to illustrate what BNWII can do and how the input must be prepared. 


\subsection{COOLING SYSTEM}

The BNW-III computer code models a modular dry/wet cooling system for a nuclear or fossil fuel power plant. The model contains four submodels:

1. a condenser

2. supply and return piping system

3. dry module heat rejection system

4. wet module heat rejection system.

This section presents an overview of the modeled cooling system followed by a description of the condenser, piping, system, and cooling towers in which the dry and wet modules are stacked.

\subsection{OVERVIEW}

The cooling system modeled by BNW-III is shown schematically in figure 1. The primary coolant medium is water, which transfers the low-availability energy from the low-pressure exhaust steam to the atmosphere. The cooling system is made up of a condenser, supply and return piping, and dry and wet modules.

The temperature relationship between the steam, water, and air for the heat rejection cycle is shown in Figure 2 .

The heat rejection process begins as low-pressure steam enters the condenser. Heat is transferred from the steam in the shell to the water in the tubes while the steam experiences a phase change. That is, the steam condenses at constant temperature, and the water picks up sensible heat over a particular temperature range. The condensed steam is returned to the feedwater circuit. At the condenser outlet the cooling water enters the supply piping to the cooling towers. It is transported to the dry cooling towers at a constant temperature. The cooling water temperature is reduced as the air flowing through the dry modules picks up rejected heat. The air flow is induced by fans located on the roof of each module.

The cooling water is then collected and taken to the wet module cooling towers by piping. There the flow is distributed to the wet modules. The 
D

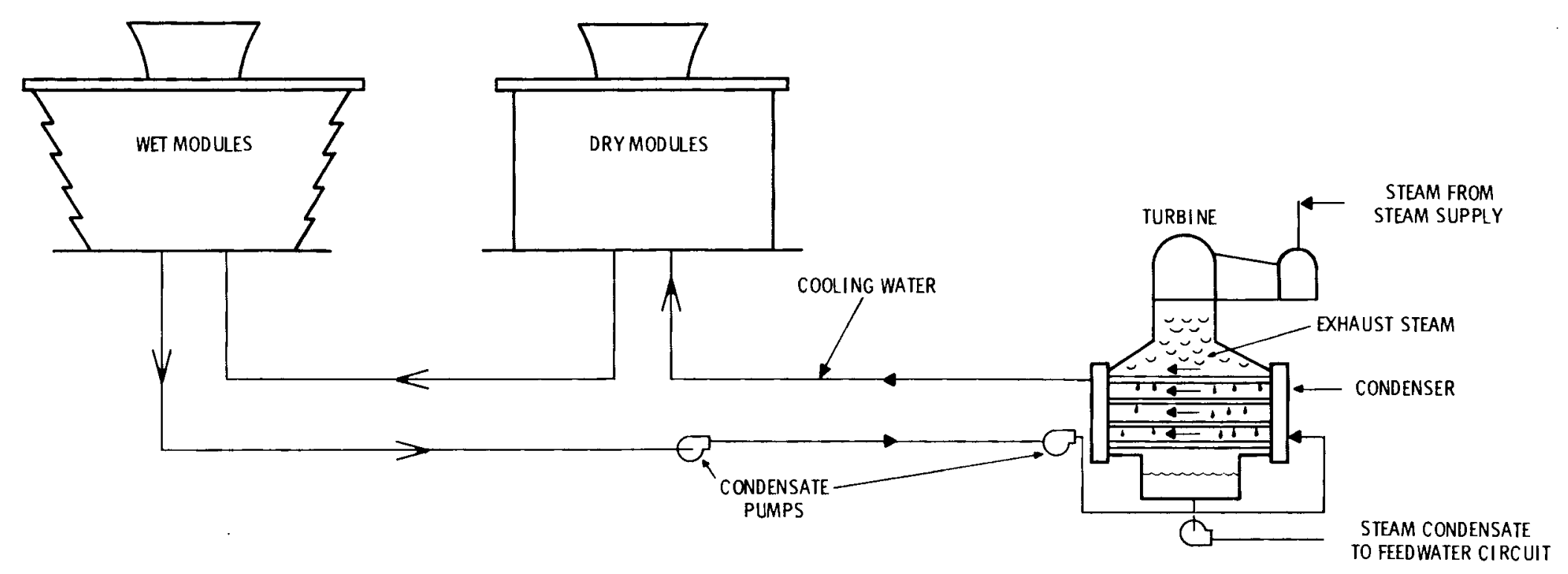

FIGURE 1. Dry/Wet Modular Cooling System 


\begin{tabular}{|l|l|l|l|}
\hline CONDENSER & PIPING & DRY TOWER & WET TOWER \\
\hline
\end{tabular}

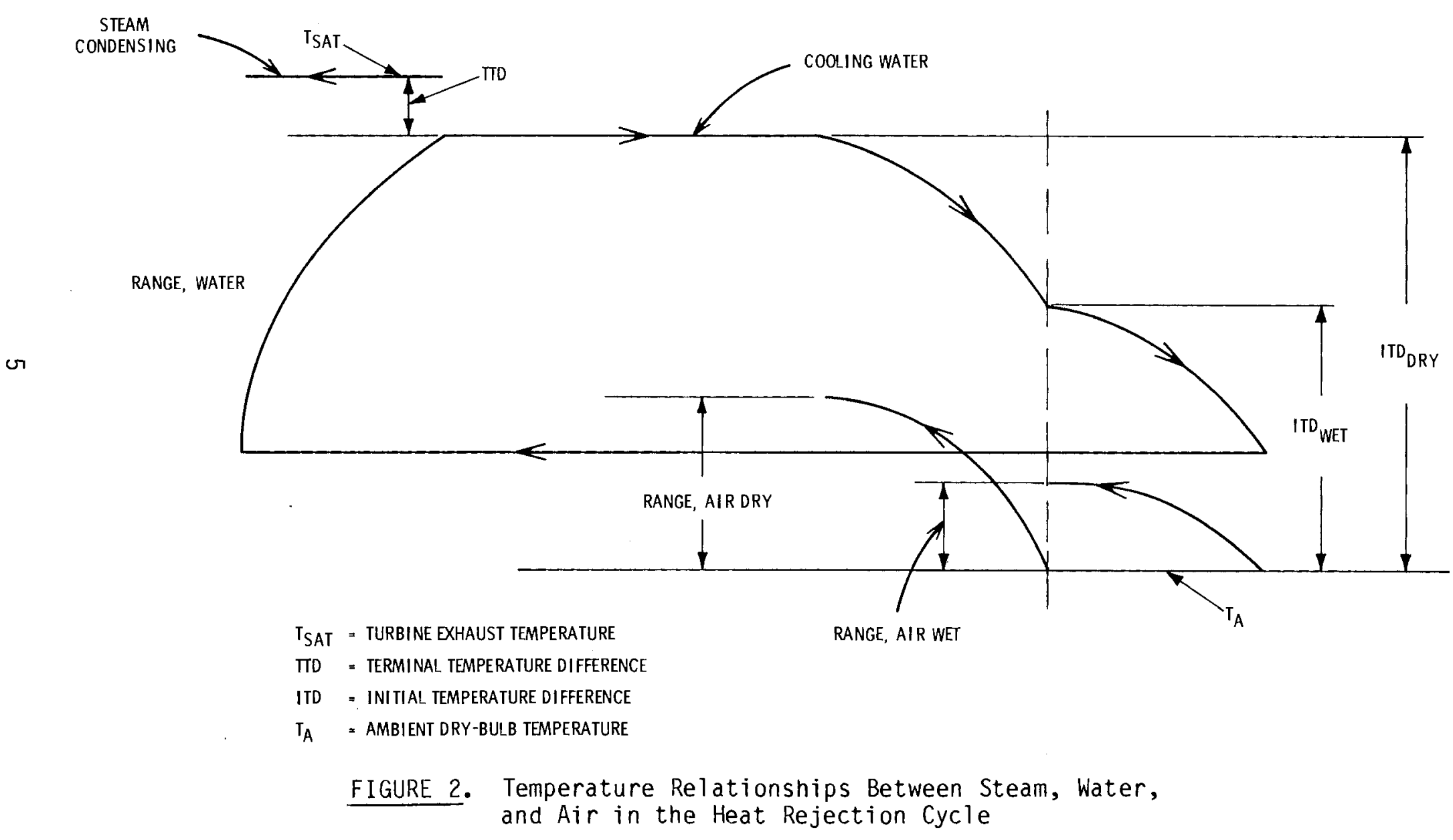


cooling water is then passed through the wet modules where the temperature drops again. The total temperature drop is dependent on the number of wet modules that are in use at the time.(a)

The cooling water is then returned to the condenser by the return piping.

\subsection{COOLING SYSTEM FEATURES}

The surface condenser, supply and return piping, and dry/wet module heat rejection systems (towers) are described in the following subsections.

\subsubsection{Surface Condenser}

The condenser is a shell-and-tube surface condenser with either one or two tube-side passes. It is designed in accordance with the Heat Exchanger Institute Standards for surface condensers on the basis of the following parameters:

- turbine exhaust steam saturation temperature

- cooling water temperature rise

- terminal temperature difference between cooling water and steam temperature

- tube-side water velocity.

\subsubsection{Piping System}

The cooling water distribution piping system is divided into the supply piping, which transports the cooling water from the condenser to the dry and wet modules, and the return piping, which transports the cooling water from the dry and wet modules to the condenser. Both the supply and return piping up to each dry or wet module are designed and costed out. It is assumed that the cost of any piping inside the modules is contained within the costs figures for the dry or wet modules. (Section 4.1 presents details on how the cost of the cooling system is calculated).

A typical supply and return piping layout designed using the code is shown in Figure 3. The supply and return piping are modeled as having identical

(a) A wet module is removed from service by turning the fan off. Water continues to flow through the wet module whether it is on or of $f$ 


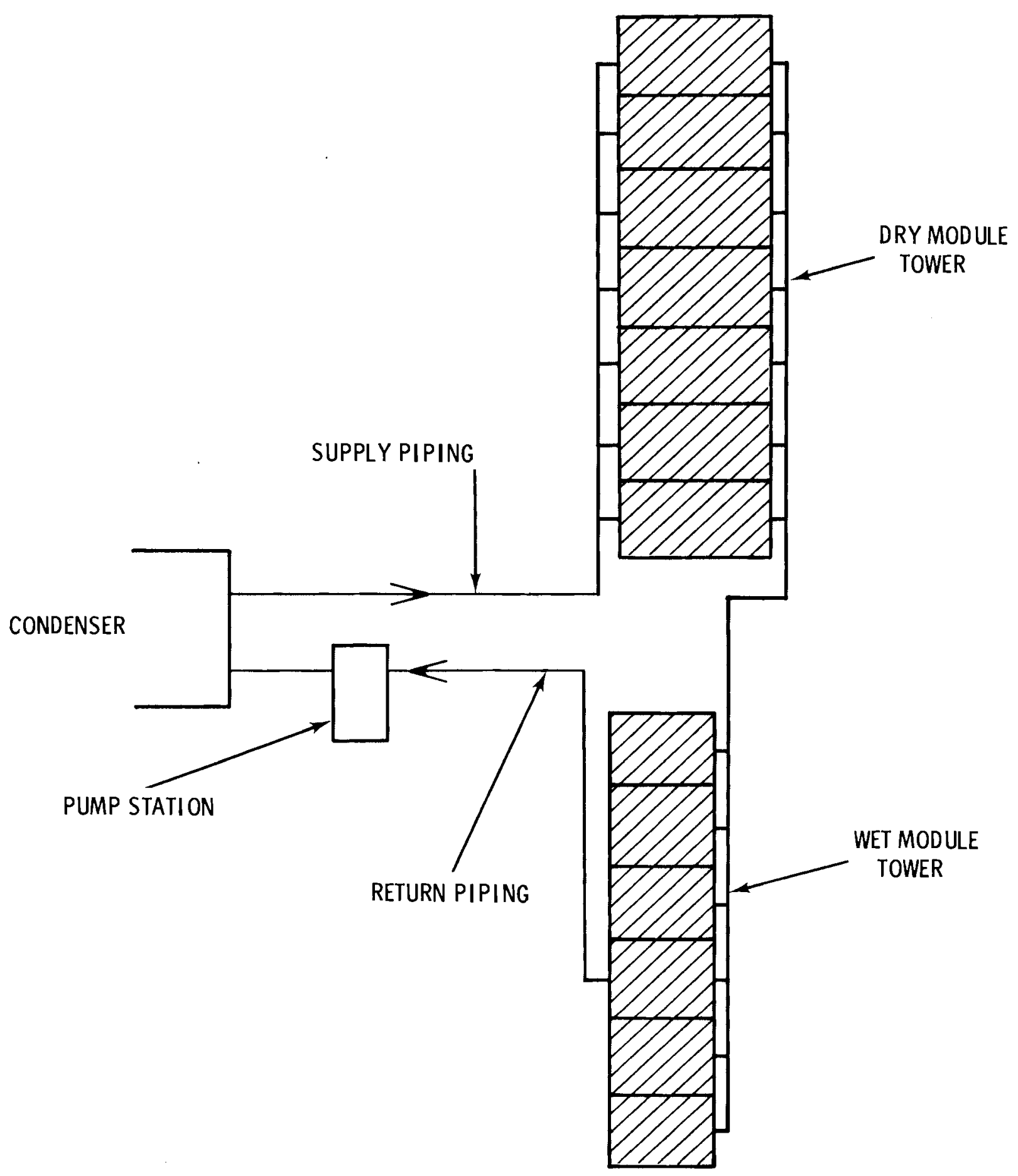

FIGURE 3. Piping Schematic 
"plan views." In addition to the pipe, the design includes specification of valves, tees, elbows, reducers and flanges, as required. All pipe, valves and fittings are designed for either 50, 75 or $125 \mathrm{psi}$ (selected by input to the code). All pipe components are assumed to be available in sizes from 12-in. to 144-in. diameters in 6-in. increments. Pipe sizing is based on the mass flow rate and design velocity. The distance from the condenser outlet to the first tower is variable (dependent on user input). Otherwise, pipe lengths are based on the tower spacing and module dimensions, which are also input to the code.

\subsubsection{Cooling Towers}

The cooling towers for both the dry and wet modules are rectangular. One cooling tower is for the dry modules, and a separate tower is for the wet modules. The size of each cooling tower is variable. As the number of dry or wet modules is varied, the size of the cooling tower varies. The dry or wet modules are stacked together as shown in Figure 3. The supply and return distribution piping runs along the total length of tower. 


\subsection{COOLING SYSTEM OPTIMIZATION RATIONALE}

This discussion of code modeling rationale describes a utility model, the operating strategy of the modeled cooling system, and plant scaling.

The cooling system is designed to minimize the power production costs of an idealized power plant using a dry/wet cooling system. The "cost" of the cooling system is defined as an incremental increase in power production costs compared to the cost of producing power with a reference power plant having a zero-cost cooling system and a conventional turbine operating at $3.5 \mathrm{in}$. $\mathrm{Hg}$. (See Section 4.1 for details on how the cost of the cooling system is calculated.)

\subsection{UTILITY MODEL}

The idealized power plant consists of one dry/wet-cooled, base-loaded power plant with a gas turbine complement(a) to provide power at higher ambient temperatures. (The reference plant requires no gas turbine complement because its turbine back pressure is constant at $3.5 \mathrm{in}$. Hg.) This idealized utility operates in an on-off mode. It supplies full power at a constant level (fixed demand during the "on" mode and no power during the "off" mode. The fraction of the time that the utility is in the "on" mode is equal to the capacity factor. Power for the cooling system fans and pumps is provided by the dry/wet plant.

The power plant can produce more than the utility system's power requirements when the temperature is below the design temperature (the ambient temperature at which the power plant, when operating all dry, has a net power output equal to the utility system's demand). Because no market exists for this excess power, the power plant is not given credit for this excess generation capacity. However, the power plant is given credit for reduced base plant fuel consumption resulting from the lower turbine back pressures.

(a) Other sources of replacement energy such as hydro or cycling plants can be simulated by appropriate changes in the capital and fuel costs used as inputs to the computer program. 


\subsection{OPERATING STRATEGY OF COOLING SYSTEM}

Throughout a year the performance of the cooling system is affected by variations in ambient air temperature. The performance of the dry and wet modules depend on the temperature difference between the water and air flowing through the modules. The higher air temperature, the less efficient the heat exchangers become, and therefore a larger number of heat exchangers are needed. The steam temperature in the condenser is adjusted to match the heat rejected by the power plant (to the condenser) with the heat that can be rejected by the wet and dry modules. The steam temperature affects the entering water temperature for the heat exchangers and the turbine back pressure. The adjusted turbine back pressure does slightly alter the power produced by the plant. Complicating the situation are the assumptions that the power plant will have only given amount of water available for evaporative cooling and that amount is to be completely used during the year. Both air temperature and mode of plant operation have an effect on the amount of water evaporated. In summary, two concerns must be considered in operating the cooling system:

- operation of the cooling system with regard to turbine back pressure, ambient temperature, and number of wet modules operating

- amount of water evaporated for a year versus the water available to the power plant.

Shown in Figure 4 is a representation of the permissible operating envelope. The turbine back pressure was chosen as the parameter to be used in evaluating how the cooling system would operate for the different ambient temperatures experienced during a year. Highlights of significant operating limits will be briefly discussed in the following paragraphs.

\subsubsection{Back Pressure Limitations}

Input for BNW-III includes an array (BPLIM) that represents limitations on the allowable back pressure of the turbine and is associated with the ambient temperatures for a year. The array establishes an upper limit on the turbine back pressure during wet module operation for the different air temperatures. The maximum turbine back pressure is also used as a limit on the all-dry module operation. 


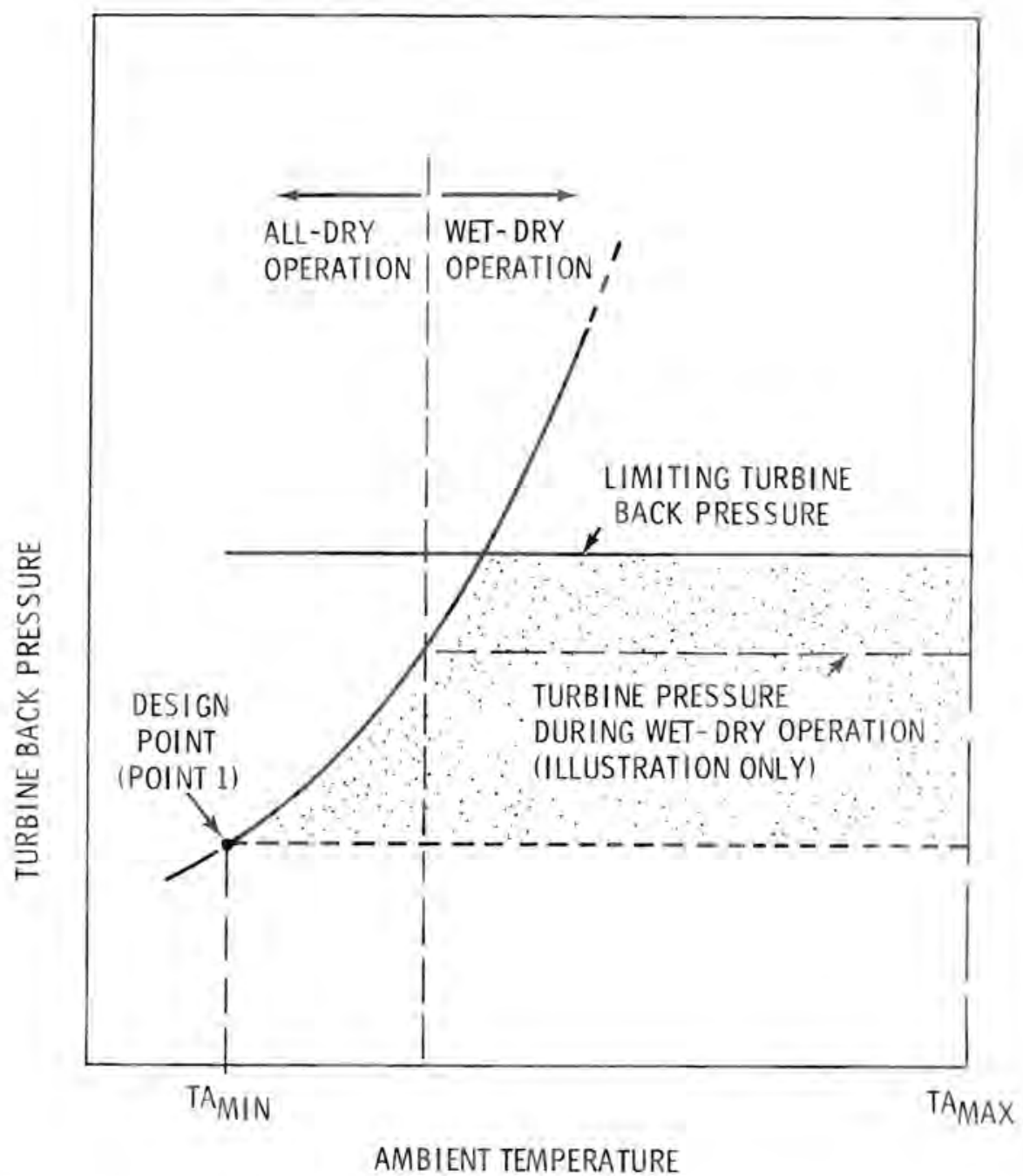

FIGURE 4. Operating Regimes for a Dry/Wet Modular Cooled Power Plant

\subsubsection{All-Dry Module Operation}

Regardless of the meteorological conditions, all the dry modules are assumed to be operating and are sized at the design conditions (point 1 on Figure 4) to just handle the heat rejected.

The operation of only dry modules throughout the year establishes another limitation curve with regard to plant operation (back pressure) and evaporation of water (see Figure 4). The all-dry back pressure curve is found by assuming that the heat rejected by the plant is handied by the dry modules and that the turbine back pressure is increased as needed as the ambient temperature increases. If the back pressure for a11-dry operation becomes greater than the 
maximum limiting back pressure (BPLIM(1)), the back pressure for that ambient. temperature and all higher ambient temperatures is set equal to BPLIM(1) + $0.1 \mathrm{in.} \mathrm{Hg}$.

\subsubsection{Wet and Dry Module Operation}

The cooling system is required to use up (evaporate) all the water available for a year and still operate within the constraints on turbine back pressure. The approach taken is to attempt to bracket the water available with water consumptions at two different back pressures.

The design procedure is to start on the hottest day, TAO max, and require all dry and wet modules to operate and to handle the heat rejected by the plant. The inlet and outlet water temperatures are known for the wet modules, so the ratio of water to air flow can be determined (basically "sizing" the wet modules). It is possible that the turbine back pressure selected results in wet modules with too many or too few transfer units for the heat to be rejected. With too many transfer units, the wet modules can reject more heat than is required, so the modules can be viewed as being oversized. If the wet modules have too many transfer units, either the turbine back pressure can be decreased or the number of wet modules decreased. The back pressure is not allowed to drop below the design point back pressure. If the wet modules have too few transfer units, the modules are undersized, and therefore the turbine back pressure is increased. The turbine back pressure is not allowed to increase beyond the limiting turbine back pressure values. More wet modules would be required if the wet modules still had too few transfer units at the limiting back pressure. The amount of water evaporated by the wet modules for the "hottest-day" ambient conditions is determined once the wet modules are properly sized.

After the cooling system is designed to handle the hottest-day conditions, the performance of the cooling system is evaluated at the next lower ambient temperature. The ratio of water to air flow is kept constant once the wet modules are sized because single-speed fans are assumed for the wet modules. The turbine back pressure is kept as constant as possible during wet tower operation by choosing, for each meteorological interval, the number of wet modules that gives the smallest back pressure variation. Because the fraction 
of heat rejected by the dry modules increases as the ambient temperature drops, the heat that must be rejected by the wet modules decreases, and therefore wet modules are removed from service. The turbine back pressure may need to be readjusted to improve the agreement between the heat rejected by the power plant and the heat rejected by the reduced number of wet modules needed, and the turbine back pressure is repeated for each ambient temperature until the dry modules can handle all the heat rejected by the power plant. The total amount of water evaporated is then compared to the water available. If the water evaporated is greater than the water available, the turbine back pressure is increased during combined wet and dry module operation, and the wet modules are redesigned. The computation of water consumption for the different ambient temperatures is then repeated. If the water evaporated is less than the water dvailable, the back pressure is reduced and the wet module design and water consumption are recalculated.

\subsection{STEAM SUPPLY AND PLANT SCALING}

As mentioned previously, the incremental cost is computed against that of a plant with a conventional turbine operating at $3.5 \mathrm{in}$. Hg with a zerocost cooling system. The choice of $3.5 \mathrm{in}$. Hg was made because it is the turbine back pressure at which the power output of conventional turbines is often rated. That is, a 1000-MWe turbine will produce 1000 MWe at $3.5 \mathrm{in}$. Hg. Higher back pressures result in less power; lower back pressures result in more power. Because BNW-III considers other than conventional turbines with 3.5-in. $\mathrm{Hg}$ rated back pressure, steam supply scaling is used. And because BNW-III designs plants operating at other than the rated back pressure of the turbine under consideration, plant scaling for heat rate is carried out. Further, because the utility model upon which BNW-III is based requires the plant to produce power for its own cooling system auxiliaries (fans and pumps), plant scaling for auxiliary power is carried out. These three scaling processes are described in more detail below. As background, Figure 5 gives the comparative heat ratio of three candidate turbines, and Figure 6 shows the relationship between the reference plant power output and the gross and net power output of the modular dry/wet-cooled plant. 


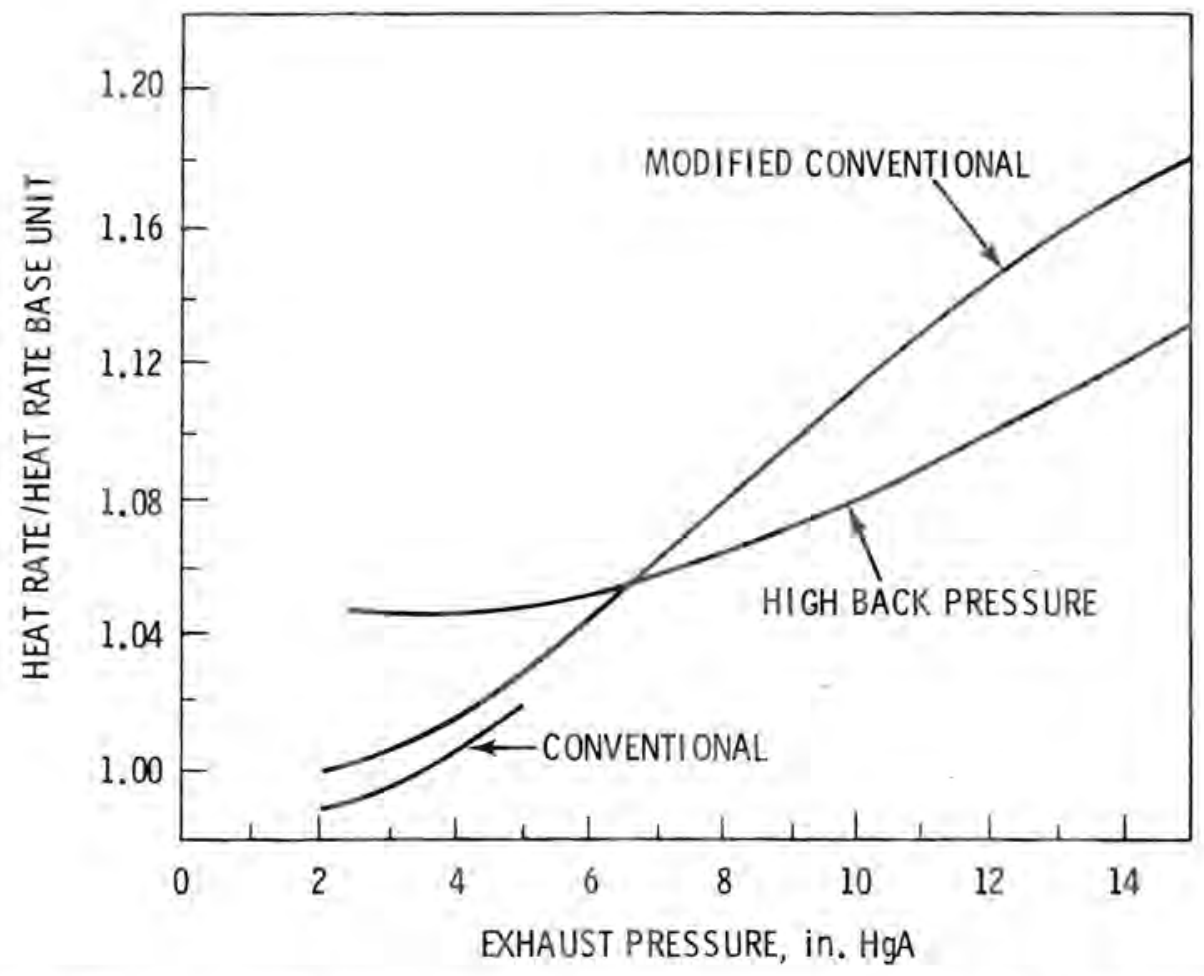

FIGURE 5. Heat Rate Versus Back Pressure--Fossil Turbines

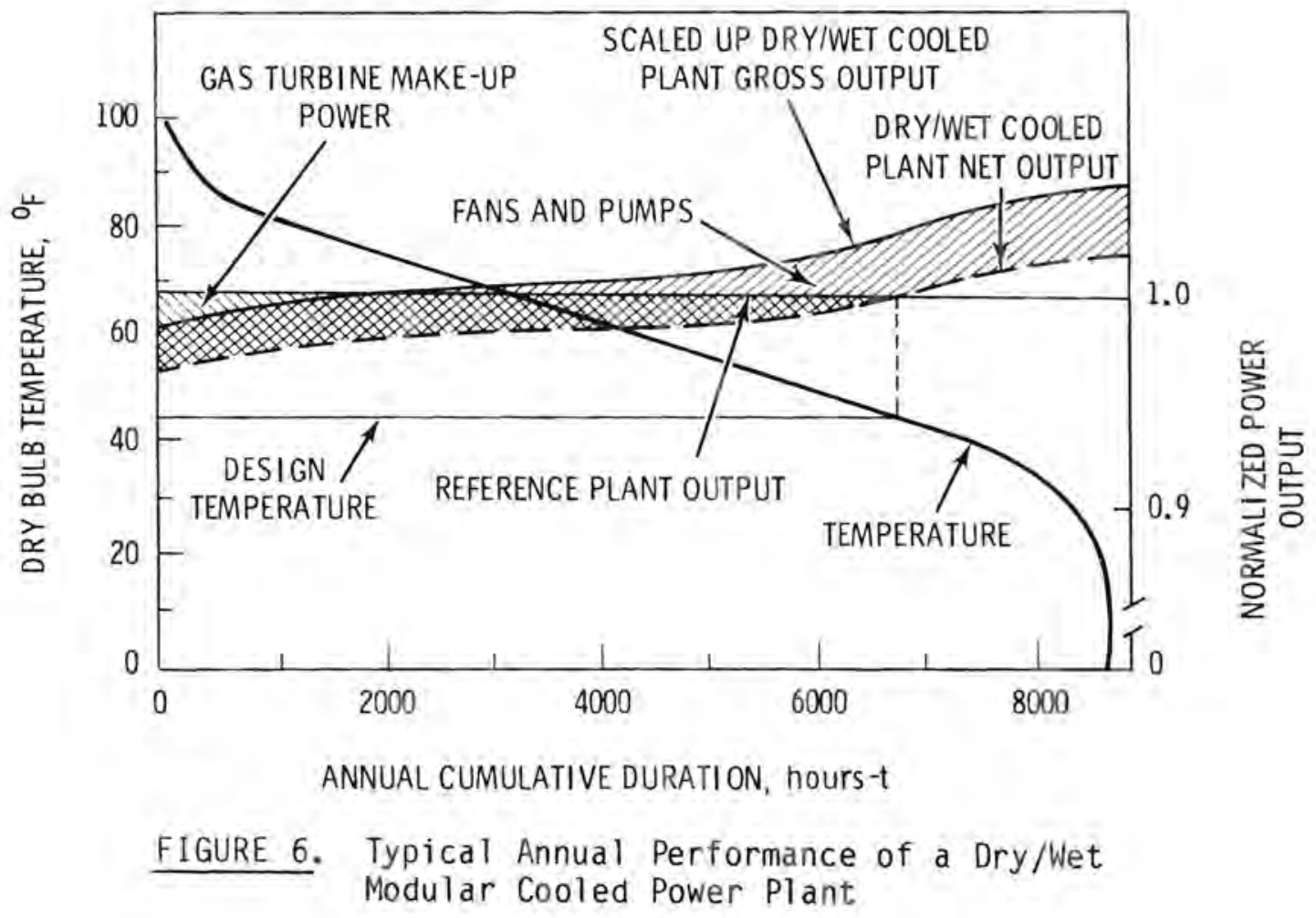


Steam supply scaling is best illustrated by an example. Assume that the turbine under consideration is a high-back-pressure turbine with a rated back pressure (the back pressure at which it delivers rated power) of $6 \mathrm{in}$. $\mathrm{Hg}$. This turbine was selected because it can operate at back pressures up to 15 in. $\mathrm{Hg}$ instead of the $5 \mathrm{in}$. Hg maximum typical of the conventional turbine. This higher back pressure capability introduced a penalty of a 5\% larger heat rate than that of a conventional turbine. This means the turbine will require a $5 \%$ larger steam supply. Therefore, the steam supply is scaled up by $5 \%$. The resulting increase in plant cost is computed by assuming that the steam supply system makes up $1 / 3$ of the nominal power plant construction cost.

Scaling for heat rate is also best illustrated by example. Suppose that, at the design temperature, the heat rejection system is capable of maintaining the turbine back pressure at $4.0 \mathrm{in}$. $\mathrm{Hg}$. At $4.0 \mathrm{in}$. Hg the high-back-pressure turbine puts out $2 \%$ more power than at the 6-in.-Hg rated back pressure. Remember that at the design temperature the output of the power plant is equal to the fixed demand of the utility system. Therefore, a power plant which is $2 \%$ larger than rated power has been designed. Hence, the size and cost of the plant must be reduced by $2 \%$. No change is made in heat rejection system size because it was sized for a turbine operating at $4.0 \mathrm{in}$. $\mathrm{Hg}$.

Consider an example of scaling for auxiliary power and heat rate. Suppose a 1000-MWe plant requires 30 MWe for fan power at the design temperature and 10 MWe for pump power for the cooling system. Thus, the plant's net power output is only 960 MWe instead of the 1000 MWe required to meet demand. Plant scaling for auxiliary power refers to scaling up the plant so that its net power is equal to the fixed demand; in this example, the required increase in plant size is $40 /(1000-40) \times 1000=41.67$ MWe, not 40 MWe, because of the increased power demands of the larger cooling system.

A trade-off exists between plant scaling and the size of the gas turbine contingent. The BNW-III optimization code takes this tradeoff into account. 
-

. 


\subsection{DESCRIPTION OF BNW-III SUBROUTINES}

The purpose of BNW-III is to design and estimate costs for a power plant cooling system consisting of dry and wet modules. The cooling system is designed and costed so that the effect of the incremental cost of the cooling system on the cost of generating electrical power can be determined.

A general overview of the program flow through the subroutines for wet/dry operation will be presented first, and then a more detailed discussion of the design of the dry modules, wet modules, and piping system will follow. A flow diagram of BNW-III is shown in Figure 7 .

The executive program of the code is BNWIII, which directs the code to the two main areas:

- optimization of five independent variables associated with the cooling system

- designing and determining cost of the cooling system.

BNWIII calls subroutine SETUP first, to read in the input and print out the variable names and values as a means of checking the conditions for a run. A quick summary of the starting conditions for the five independent variables and cost factors used in the code is provided by subroutine INPSUM. Subroutine SSCALE scales the steam supply system to obtain the incremental cost of the steam supply when providing the specified power output of the plant (PSIZE) at the rated back pressure of the turbine. The steam supply is scaled to account for the use of turbines other than a conventional turbine, such as a modified conventional turbine. The turbine back pressure affects the thermal efficiency of the plant and thereby the heat rejected by the power plant.

In BNW-III, the user can select between an optimized design where from one to five of the five independent variables is adjusted to produce a design with the lowest incremental cost or a case where all five variables are held constant. The independent variables are:

$$
\begin{aligned}
& \text { AFLOPM - air flow rate per dry module heat exchanger } \\
& \text { RANGE - temperature range of the cooling water entering and leaving the } \\
& \text { condenser }
\end{aligned}
$$




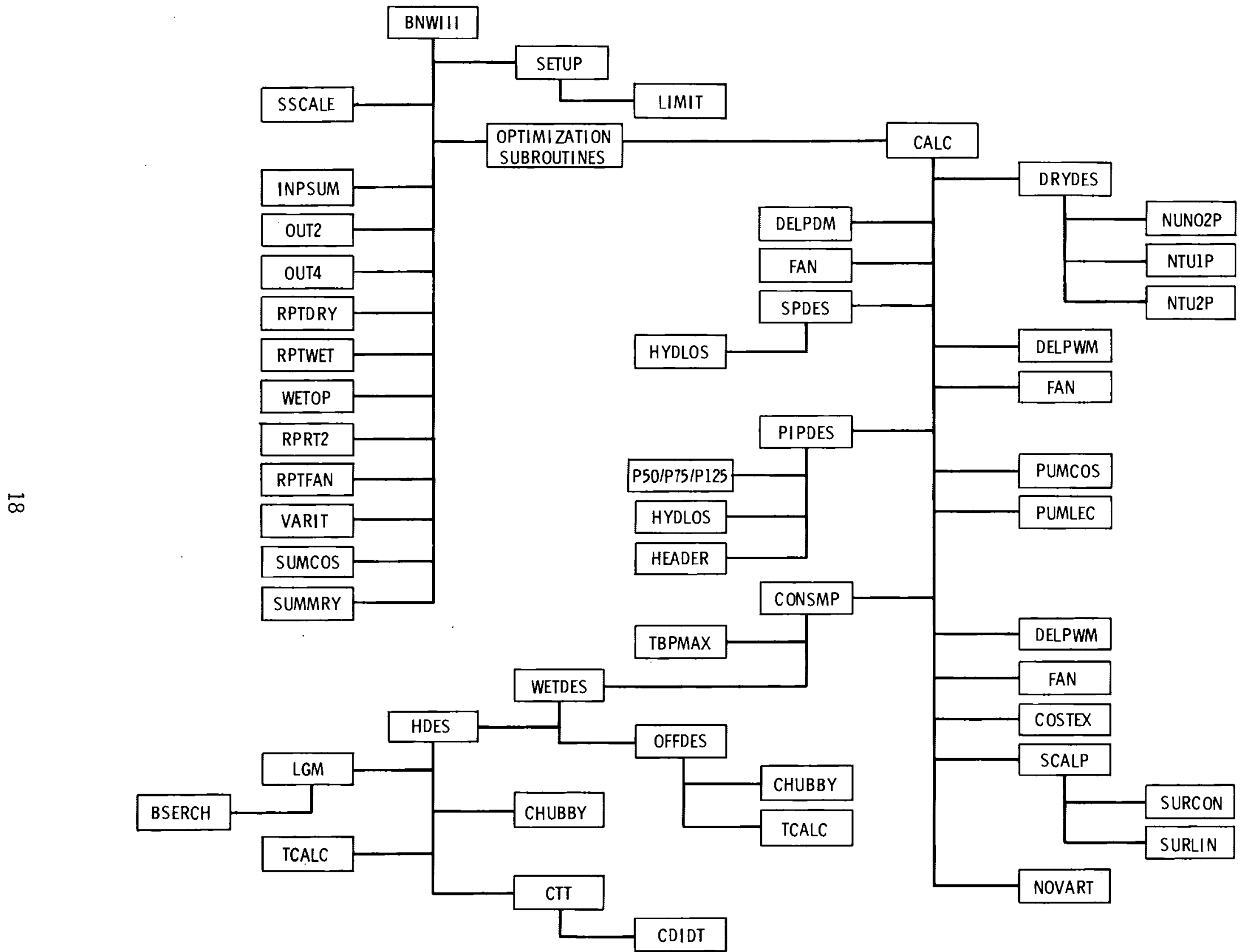

FIGURE 7. Flow Diagram of BNW-III 
TTD - terminal temperature difference between the steam entering and the cooling water leaving the condenser

DRYMOD - number of dry modules

WETMOD - number of wet modules.

When the cooling system is to be optimized, a set of optimization subroutines are called from subroutine BNWIII. They in turn call subroutine CALC a number of times. For a single case, CALC is called once from BNWIII. Subroutine CALC calls the various subroutines which design and cost the cooling system from the five independent variables.

After the final design is completed (either optimized or a single design), summaries are printed of the various systems designed and the operating conditions of the cooling system. The following is a list of the output subroutines and an indication of the type of information provided.

- Subroutine 0UT2 reports steam supply costs due to the rated back pressure.

- Subroutine OUT4 reports the scaling of plant and steam supply due to operation at design back pressure rather than rated back pressure of the turbine. Subroutine OUT4 also reports the effect of scaling to account for the power to run the pumps and fans of the plant and steam supply.

- Subroutines RPTDRY and RPTWET give short summaries of the parameters for evaluating the performance of the dry and wet modules.

- Subroutine WETOP presents in tabular form the operation of the wet modules as a function of an average yearly meteorological profile.

- A summary of the piping system (components and costs) are printed by subroutine RPTPIP.

- Parameters for the condenser are summarized by subroutine RPTR2.

- Subroutine VARIT determines the variations of the turbine, power plant and cooling system operation as a function of meteorology.

- A summary is printed out using write statements in BNWIII. 
- Subroutine SUMCOS summarizes the capital and incremental costs for the different systems for the plant.

- A summary of the wet and dry modules and costs for the plant are written out by subroutine SUMMRY. The values for the wet and dry modules in SUMMRY have been scaled up to account for the power consumed by the fans and pumps.

\subsection{DESIGN AND COSTING OF THE COOLING SYSTEM (SUBROUTINE CALC)}

Very few calculations are made in CALC; rather it is used to call subroutines which do the design calculations of the various components of the cooling system. The dry cooling towers are designed first in subroutine DRYDES. They are designed so that the heat rejected by the power plant at the design ambient temperature uses all the dry modules. The steam temperature, total water flow rate, and turbine back pressure are determined for the power plant in addition to the performance of the dry heat exchangers (number of transfer units, effectiveness).

The water-side pressure drop for the dry modules is then calculated. Subroutine DELPDM empirically calculates the pressure drop based on the water flow rate. Subroutine DELPDM also determines the pressure drop and horsepower required for the fans in the dry modules from input correlations to the code. If desired, a more exact fan design is determined in subroutine FAN. (a) To call FAN, a read-in control variable (FDELP) is set equal to FAN. Subroutine FAN designs the fans using a set of Hudson fan curves (Hudson Products Corporation 1967). If the user does not need a detailed fan design, FDELP should be read in as CORR. (Refer to Section 5.2, Input, for more information).

The condenser is designed in subroutine SPDES. The number of tubes per shell, heat transfer surface area, and head rejected through the condenser are determined.

Next the water-side pressure drop across the wet modules is calculated in subroutine DELPWM by using a correlation whose coefficients are input to the

(a) Subroutine FAN should be used with caution because it has not been fully checked out. 
code. The pressure drops for the wet and dry modules along with pressure drops in the piping and condenser are used to determine the size of the pumps for the cooling system.

A general piping system is designed next in subroutine PIPDES. The piping consists of the supply and return piping connecting the condenser to the dry and wet towers, the distribution piping to the dry and wet modules, and the piping between the two towers. The cost of the components and the pressure drop for the piping system are determined.

Pump and valve cost for the pump station are determined in subroutine PUMCOS, which is called from CALC. The pressure drops of the dry and wet modules, piping system, and condenser determine the dynamic head to be made up by the return pumps and therefore affect the cost of the pump system. The pump motor electrical costs are determined from the horsepower of the pumps and is calculated in subroutine PUMLEC.

The pressure drops throughout the cooling system are used with the water flow rate to determine the power to run the pumps. The pump power for the wet and dry modules and the power to run the fan system for the dry modules are combined to determine a scaling factor with which to compute the gross power output of the plant. The power output is boosted to provide the power to run the pumps and dry module fans, in addition to producing the electrical power to be sent for distribution (PSIZE).

Subroutine CONSUMP determines the performance of the cooling system (dry and wet modules) and defines the operating point of the cooling system such that the water available for a year is evaporated in a year's time. The turbine back pressure and meteorological conditions are important factors that affect the wet tower design and amount of water evaporated. Once the wet tower has been designed, the actual air flow rate through the modules has been determined and the fan system designed accordingly. Either subroutine FAN or DELPWM is used, depending on whether FDELP is set equal to "FAN" or "CORR" in the input to the code. The power needed to run the fans for the wet modules is dependent on the number of wet modules in operation. The number of wet modules in operation is dependent on the point at which the system is operating on the yearly temperature profile. 
The cost of the wet and dry modules is calculated from empirical expressions based on the water flow rate and horsepower required for the fans in subroutine COSTEX. This subroutine is called from CALC.

Subroutine SCALP uses the pump power and power to run the fans for the dry towers to determine the scaling factor for the power to be generated by the plant. The scaling factor is applied to several parameters of the cooling system to account for the effect of the increased power output. The increased costs of fuel, land, piping, and condenser are the result of scaling the power. The cost of the condenser is calculated in subroutine SURCON, which uses Westinghouse cost data.(a) The total cost for the towers and maintenance costs are also determined in SCALP.

The incremental cost of operating the designed cooling system for the various meteorological ambient temperatures is determined in subroutine NOVART. The cost is affected by the power output of the plant at a specific ambient temperature which, if it is less than PSIZE, must be made up by auxiliary power. The power to run the fans for the operating wet modules at the different ambient temperatures must be supplied by auxiliary power also. There is also an increased fuel cost due to the off-design conditions.

\subsection{DESIGN FOR THE DRY MODULES (SUBROUTINE DRYDES)}

The design of the dry modules is based on an iteration of the steam temperature leaving the turbine until the heat rejected by the dry modules is approximately equal to the required heat rejection of the power plant. The number of dry modules (DRYMOD) and air flow rate per module (AFLOPM) are the independent variables that play a large part in defining the performance of the dry modules. The water flow rate is calculated from the heat rejected by the power plant and the temperature difference of the water (RANGE). The number of transfer units for the heat exchangers is calculated using the overall heat transfer coefficient. The effectiveness of the heat exchanger depends on the arrangement and the number of transfer units. A counterflow heat exchanger is

(a) All costs that are computed internal to the code, that is, costs not furnished by code user input, are in January 1976 prices. Piping is an example of such a cost. 
evaluated in subroutine NUN02P. The effectiveness of a single-pass crossflow heat exchanger is found from tabular data in subroutine NTU1P. Two-pass crossflow heat exchangers are evaluated in subroutine NTU2P. The number of passes is input as is the variable to select either the tabular approach of the above subroutines or an analytical expression for evaluating the effectiveness of the heat exchanger. The design back pressure of the turbine is established from the steam temperature.

\subsection{DESIGN OF WET MODULES: CONSUMPTION OF WATER AVAILABLE (SUBROUTINE CONSUM)}

BNW-III simulates one mode of plant operation by maintaining as constant a turbine back pressure as possible, once the use of the wet modules becomes necessary for heat rejection. All the dry and wet modules operate on the hottest day; at lower ambient temperatures all the dry modules operate, but only the minimum number of wet modules required are in operation. Because the wet modules operate at constant water flow and because they use constant-speed fans, the air flow is constant when they are operating.

For a given dry heat exchanger design, the amount of water evaporated during a year is dependent on the turbine back pressure chosen. If the back pressure is too high, not enough water will be used; if the back pressure is too low, too much water will be used.

The first step in evaluating the performance of the wet modules is to establish any limitations on the operating conditions for the wet modules. The heat rejection capability of a cooling system consisting of only dry modules at each of the meteorological ambient temperatures is one such limitation. The turbine back pressure is computed in subroutine TBPMAX for each ambient temperature using only the all-dry system. If any of the turbine back pressures exceed the allowable turbine operational limits (input, BPLIM array) the maximum back pressure is held at the operational value for that and all higher ambient temperatures.

The next step is determine the turbine back pressure performance for the combined system of dry and wet modules which will evaporate the water available. The procedure is to start at the hottest-day conditions, assuming all the wet and dry modules are operating at some specific turbine back pressure 
estimated in subroutine CONSMP. The hottest-day conditions are chosen because all the wet modules are to be operating, and the highest heat load will be rejected by the wet modules at that temperature. This computation is carried out by subroutine HDES, which, from a knowledge of the wet module characteristics and the inlet and exit water temperature, determines the air flow that will give a ratio of water-to-air flow that will permit the wet tower modules to reject the required amount of heat. (The air flow remains constant while the module is operating.)

HDES also computes the rate at which water is evaporated during the hottest meteorological interval. If the heat rejection capacity of the wet towers is too small (too few wet modules) or too large (the code does not permit driving forces to get too small as to prevent negative driving forces), then the code reverts to subroutine CONSMP for a new turbine back pressure. If no acceptable turbine back pressure exists (within operating limitations), the code reverts to subroutine CALC. If the code is optimizing the design, a new set of independent variables is chosen and the design is started all over. If only a single case is being run, the code prints out a message that the cooling systems cannot be designed with the five independent variables chosen.

Subroutine CONSMP is concerned with adjusting the back pressure within the constraints of the system until evaporation uses up the water available or an acceptable back pressure cannot be found. Subroutine WETDES evaluates the performance of the wet modules at the different back pressures determined in CONSMP. Subroutine WETDES determines the split in the heat rejected by the dry modules and the heat that must be rejected by the wet modules for the different meteorological temperatures.

Subroutine HDES makes use of four subroutines: LGM, CHUBBY, CTT, and TCALC. Subroutine LGM computes the largest liquid-to-air ratio that does not result in the operating line crossing the saturation line (this would give negative driving forces). Subroutine CHUBBY computes the number of transfer units (NTUs) required, given the inlet and exit water temperature and the ratio of water flow to air flow. Subroutine CTT determines the point on the saturation line where the slope is the same as that of the operating line for later use in wet module computations for lower ambient temperature by subroutine OFFDES. 
Subroutine TCALC computes the temperature of air given its enthalpy, relative numidity, and the atmospheric pressure. Two other subroutines which are associated with HDES are CDIDT and BSERCH. CDIDT computes the slope of the saturation line for use by subroutine CTT. Subroutine BSERCH calculates the temperature where the operating line and saturation lines are tangent as part of subroutine LGM's search for the maximum ratio of water flow to air flow.

The amount of water evaporated during the remaining meteorological intervals must be computed to determine the total water used. This is done in a stepwise manner starting at the next lowest meteorological interval and continuing one meteorological interval at a time until the ambient temperature is low enough that the entire heat rejection can be carried out by dry modules alone. Since the wet towers operate at constant water flow and use constantspeed fans, the only way to reduce the wet tower heat rejection is to turn fans off, i.e., remove wet tower modules from service. The goal to to keep the turbine back pressure as close to the estimated value as possible during all the meteorological intervals. The selection of the number of wet modules in operation for an ambient temperature is based on keeping the back pressure constant. The performance (heat rejected, water evaporated) of the wet modules is evaluated in subroutine OFFDES at the selected turbine back pressure.

The number of operating wet modules is then determined in subroutine WETDES by comparing the heat to be rejected by the wet tower to the heat rejection per module. The back pressure sometimes has to be modified slightly to ensure proper heat rejection, and the performance of the wet modules is summed for the meteorological intervals that the wet modules are being operated. The comparison of evaporated water to available water is computed in subroutine CONSMP to determine whether the cooling system design is finished. If the amount of evaporation does not match water available, the back pressure is adjusted and the computation of wet module design and water consumption are recalculated. If more water is evaporated than available, the process starts again on the hottest day except at a higher back pressure. If less water is evaporated than available, a lower back pressure would be assumed for the nottest day. The back pressure is adjusted through bracketing iterations until the water evaporated is the same as the water available. 


\subsection{DESIGN OF PIPING SYSTEM (SUBROUTINE PIPDES)}

The piping system consists of the supply and return piping between the towers and the condenser, the piping that distributes the water to the wet and dry modules, and the piping between the two towers.

The costs for the components of the piping system are dependent on the system pressure. The pressures that can be selected are: 50, 75, and 125 psi. The selected pressure is used to specify the subroutine (either P50, P75, or P125), which contains cost data for $90^{\circ}$ elbows, $45^{\circ}$ elbows, reducer costs, tee costs, and aboveground and belowground pipe costs for pipe diameters ranging from $12 \mathrm{in.} \mathrm{to} 144 \mathrm{in}$. in 6-in. increments. The system pressure is provided by input to the code.

The pipe diameter is determined from the water flow rate, and as flow is diverted, as to the dry or wet modules, reducers are added and a smaller pipe diameter selected for the next section of piping. Subroutine HEADER determines the diameter from the flow and also the cost of tees, reducers, elbows, and the pipe itself for a section of piping. The pressure drop for the section of pipe is calculated from the head loss found by subroutine HYDLOS. 


\subsection{COMPUTER PROGRAM}

This section describes the BNW-III computer program developed for optimizing the costs for a modular dry/wet cooling tower. A general description of the code's functions is followed by detailed listings of sample input and output.

\subsection{GENERAL INFORMATION}

The modular dry/wet cooling tower cost optimization code is coded in ASCII FORTRAN. It was compiled and executed on a UNIVAC 1100/44 (ASCII FORTRAN). Central memory requirements (actual words) are approximately 35,000 for the UNIVAC 1100/44. Execution time ranges from 30 to 300 seconds on the UNIVAC, depending on whether a full optimization is done or only a partial optimization (in which some independent variables are constrained) is required. Execution time is also affected by the proximity of the starting point to the final conditions, as well as the number and severity of the constraints imposed.

The modular dry/wet cooling tower code can be used not only for optimization of a particular system but also as a point design tool. All independent variables can be constrained to their design points, and the code will then design a system corresponding to these values. This will be discussed in more detail in the output section of this user's guide, Section 5.3 .

Particular care should be used to avoid overconstraining the model. Experience has shown that the optimization scheme may fail to converge or may converge to a false minimum if the constraints are too numerous or too severe. Input variables which impose constraints and thus could interfere with optimization are:

- air flow rate per dry module (FXAFLO, DMMAXA, DMMINA)

- air flow rate per wet module (WMMAXA, WMMINA)

- water flow rate per dry module (DMMAXW, DMMINW)

- water flow rate per wet module (WMMAXW, WMMINW)

- condenser water temperature range (FXRNGE)

- condenser terminal temperature difference (FXTTD)

- number of dry modules (FXDRYM) 
- number of wet modules (FXWETM)

- turbine back pressure limits (BPLIM).

The subroutines in which these variables are active, and the mechanisms through which they function to impose constraints, are summarized in Table 1.

The complex interaction of variables in the system being optimized makes it extremely difficult to predict which constraints are likely to cause problems in any one case. In general, an unconstrained case should be run before any attempt is made to apply constraints. (a)

The BNW-III program has not been run through a wide range of runs. No serious problem areas have been found in the runs to date. (b) However, problems can be encountered by extending the variables of the program outside their range of applicability. This can be done by setting the initial starting point of the program at unreasonable values or setting other input variables at unreasonable values.

As an aid to visualizing the interrelationships among the subprograms of the code, a subroutine linkage chart is shown in Figure 8. It indicates which subroutines may call or be called by other subroutines.

\subsection{MODULAR DRY/WET CODE INPUT}

All input to the program is by punched cards. A sample input listing is printed out as Figure 9. In the following input description, the Card Type symbols (in the first column of Figure 9) correspond to the symbols in the input summary of the code output listing shown as Figure 10.

(a) In particular, values of BPLIM well above those allowed by the actual turbine limits may permit subroutine SHOT to find one or more workable plant designs. Once a workable plant design is found, subroutine SERCH often finds an optimum design well within conventional turbine limits (see Section 6.0).

(b) Subroutine FAN has not been fully checked out; therefore the use of FDELP = FAN is not recommended. Similarly subroutine CHANGE has some glitches; therefore, to avoid using CHANGE, set DPDMIN and DPWMIN equal to zero. 
TABLE 1. Subroutines Containing Constraint-Imposing Variables

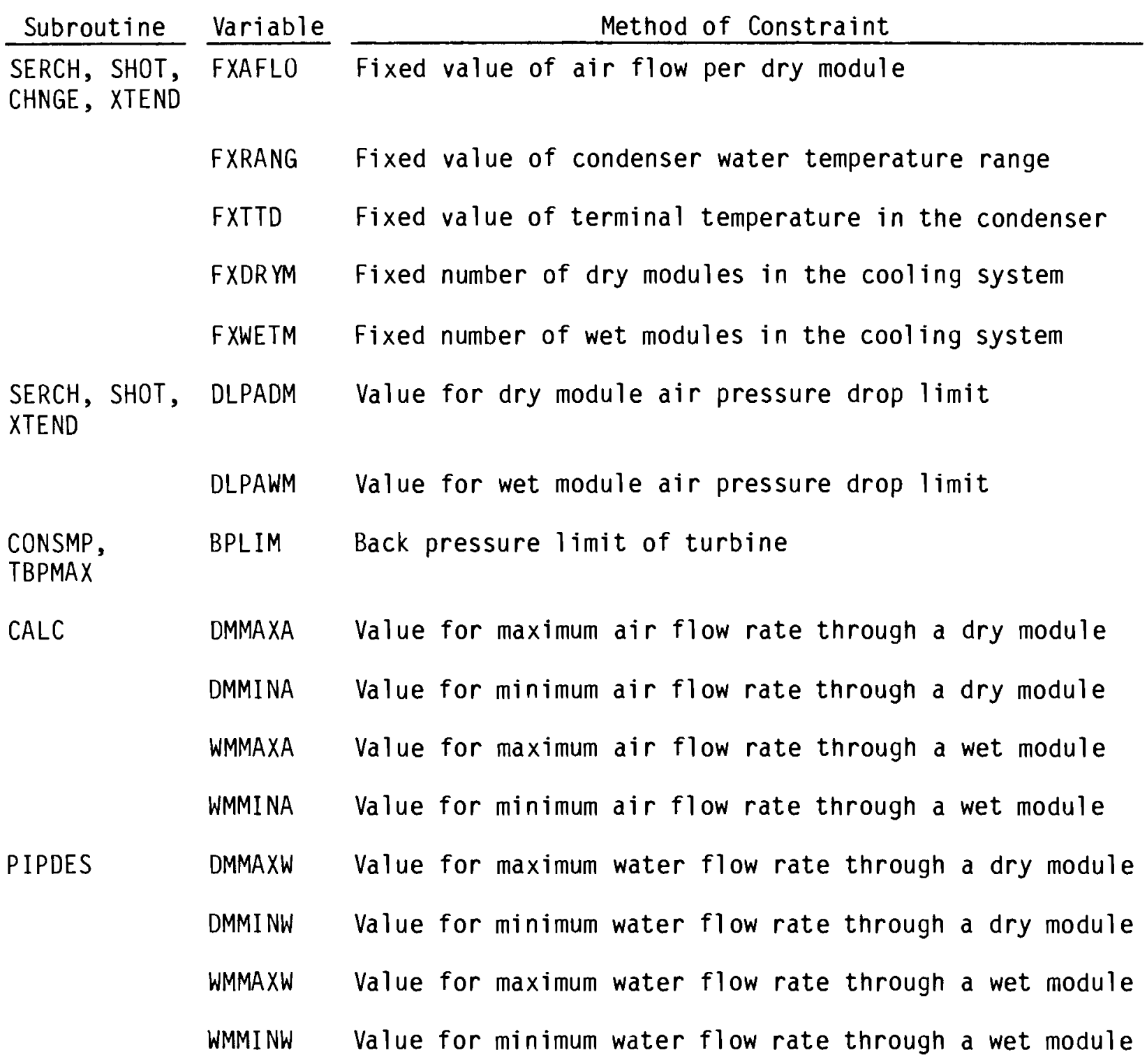




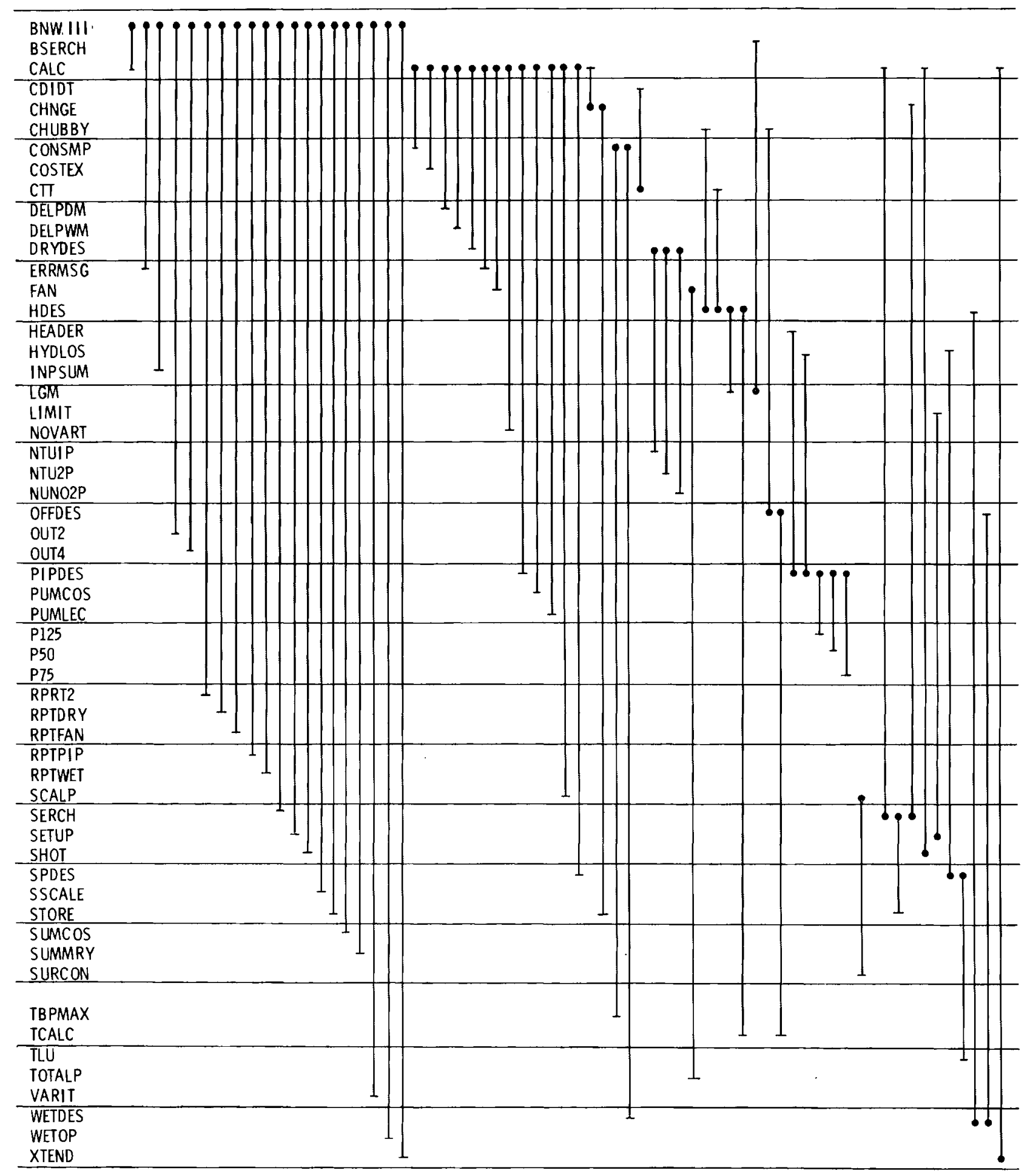

FIGURE 8. BNW-III Subroutine Linkage Chart 


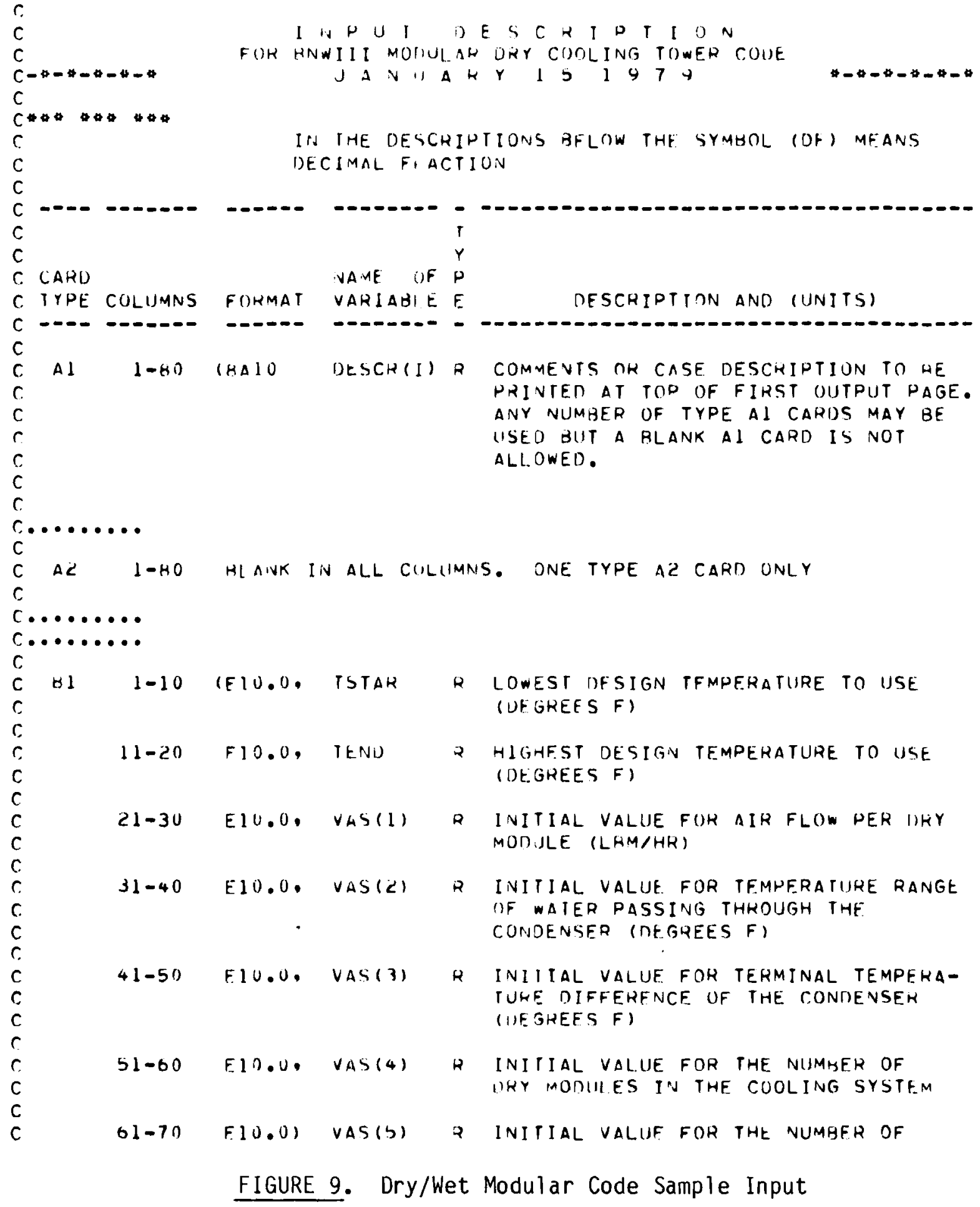




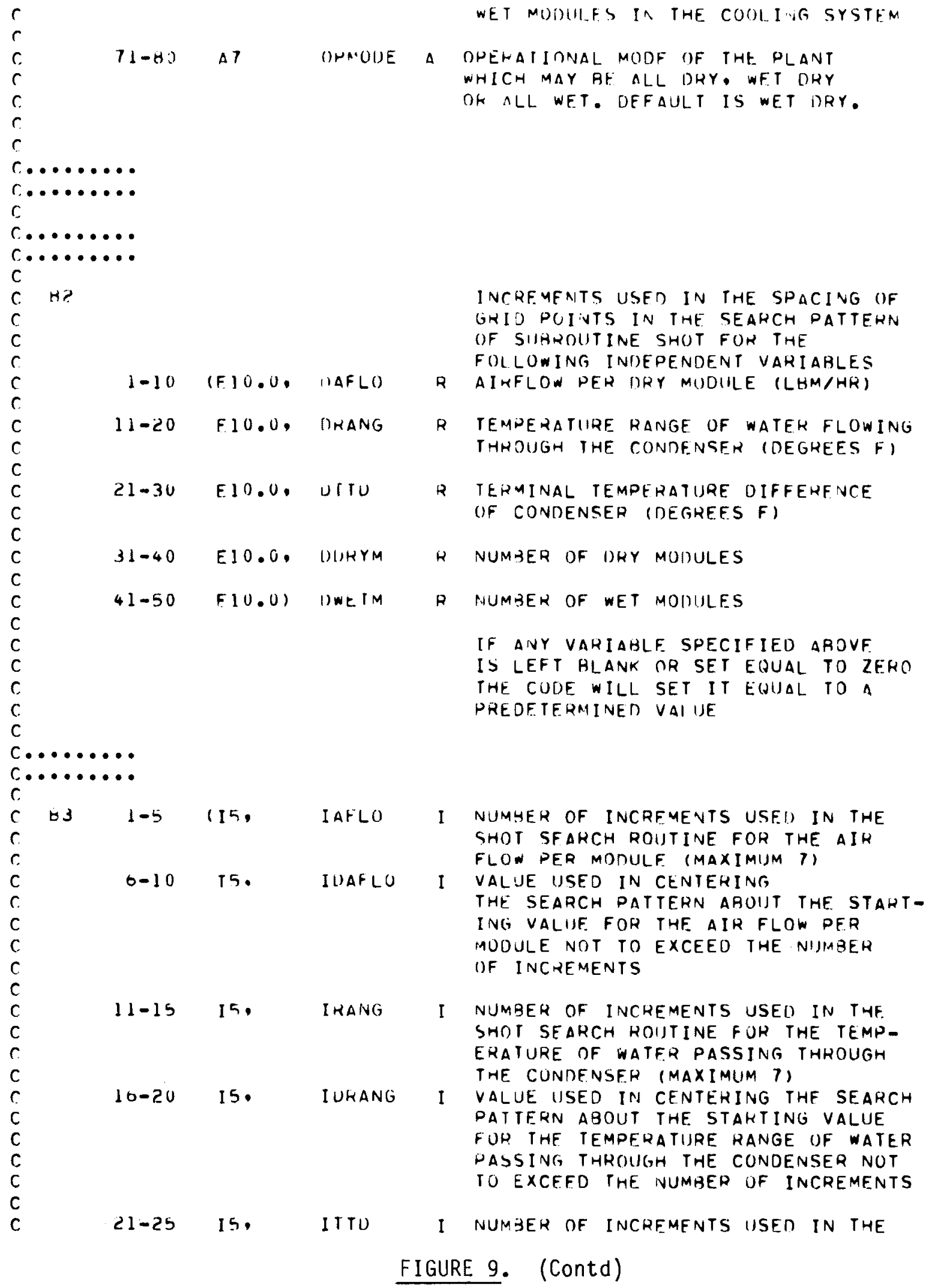




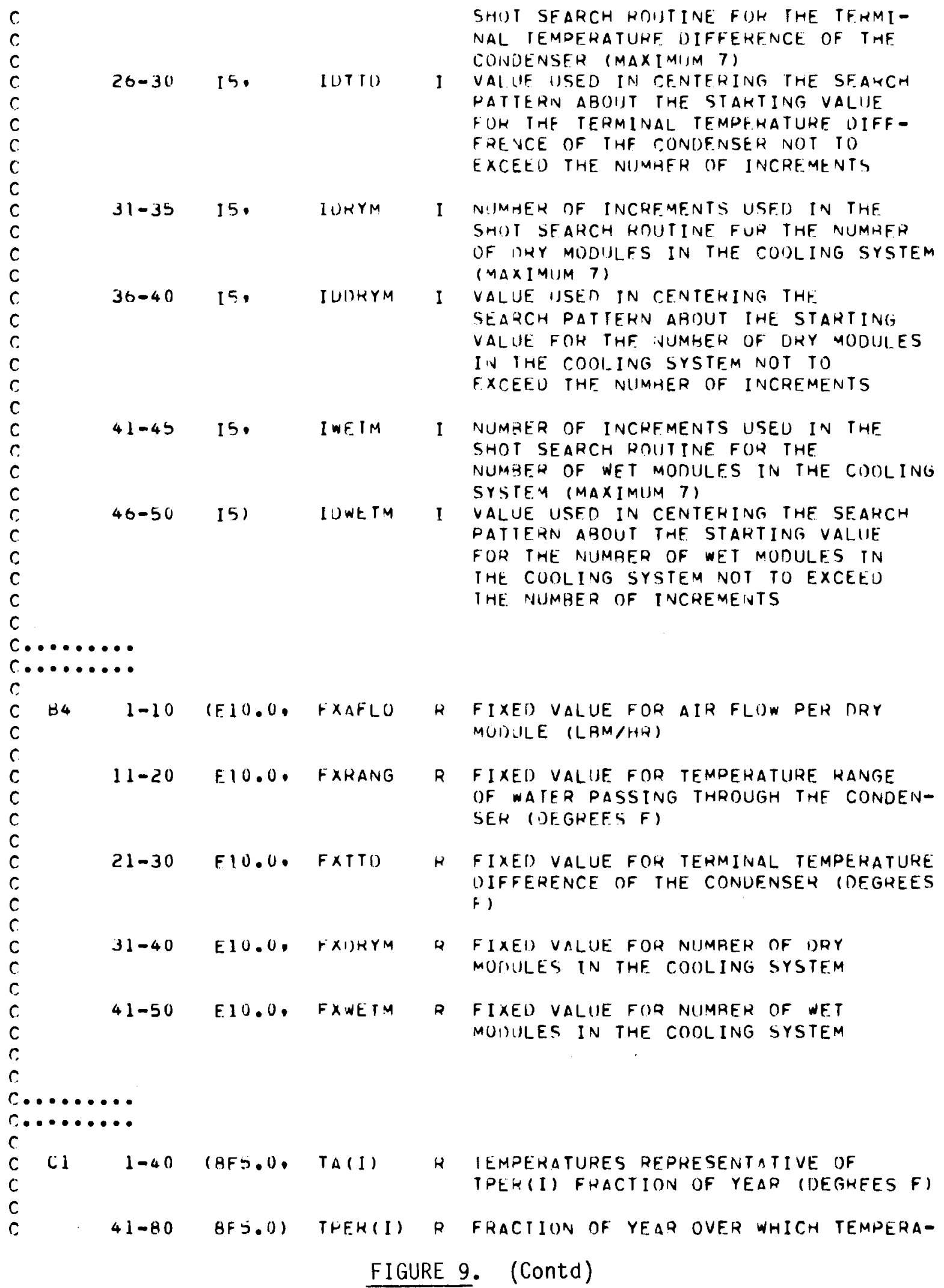




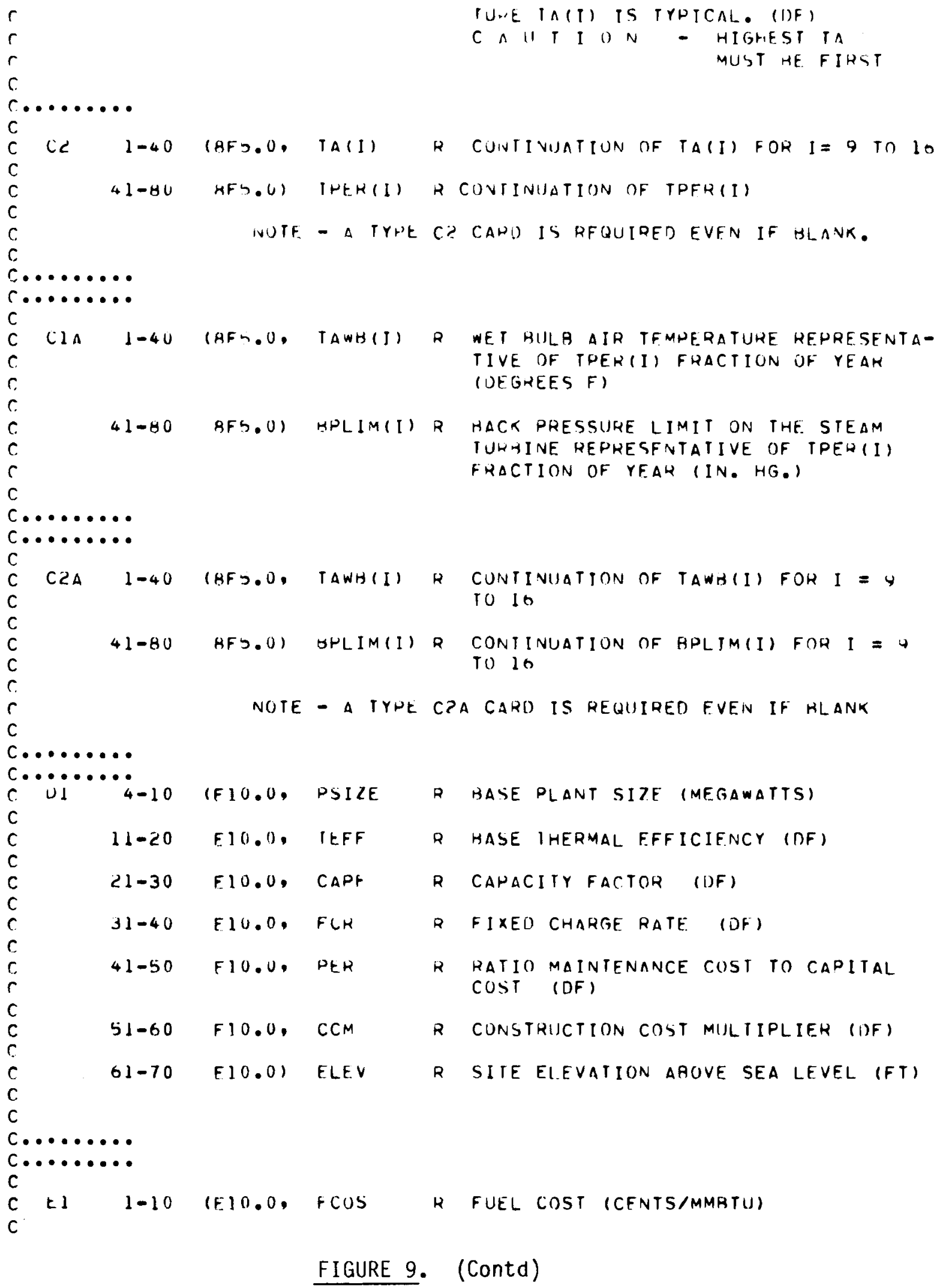




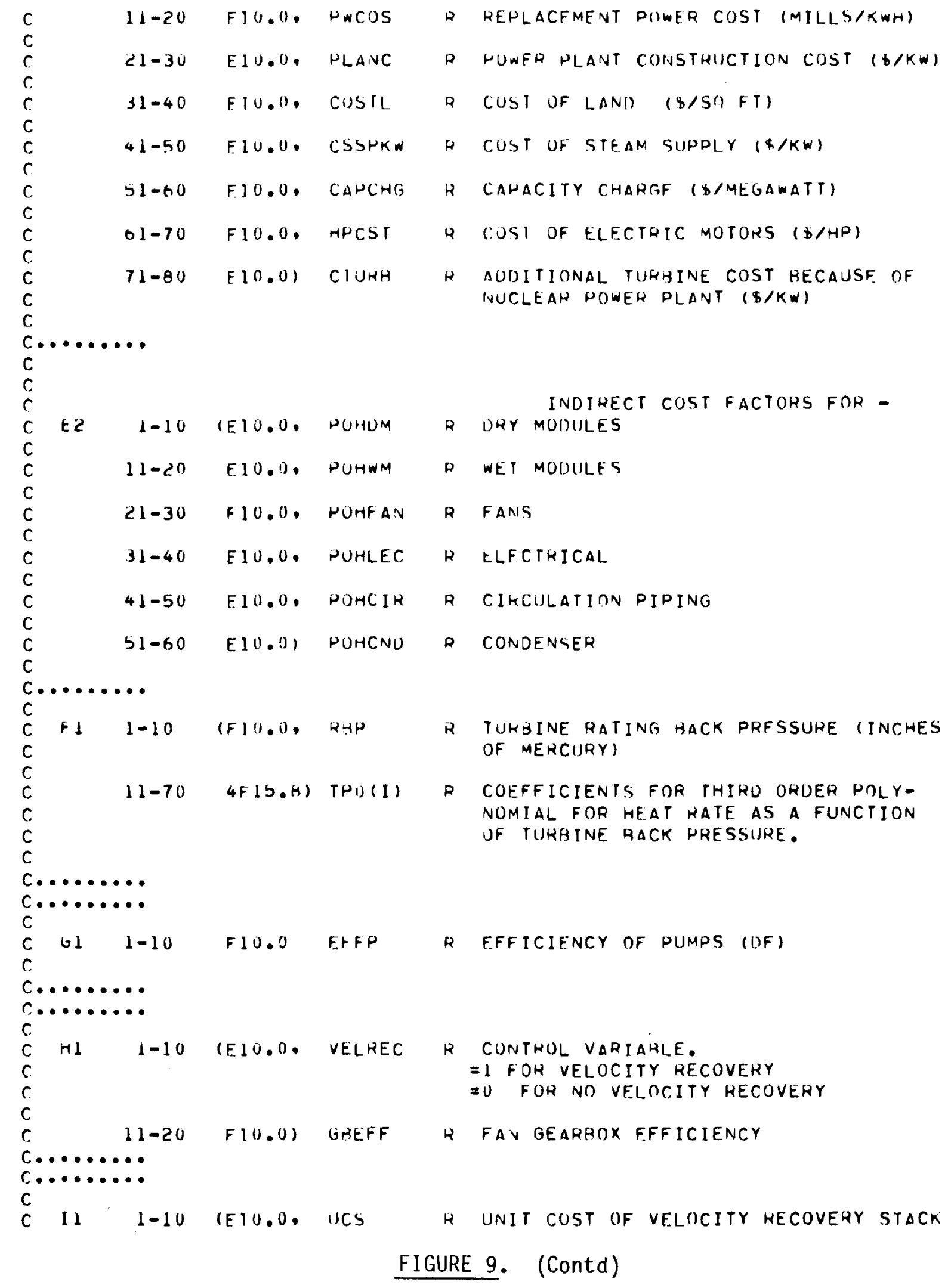




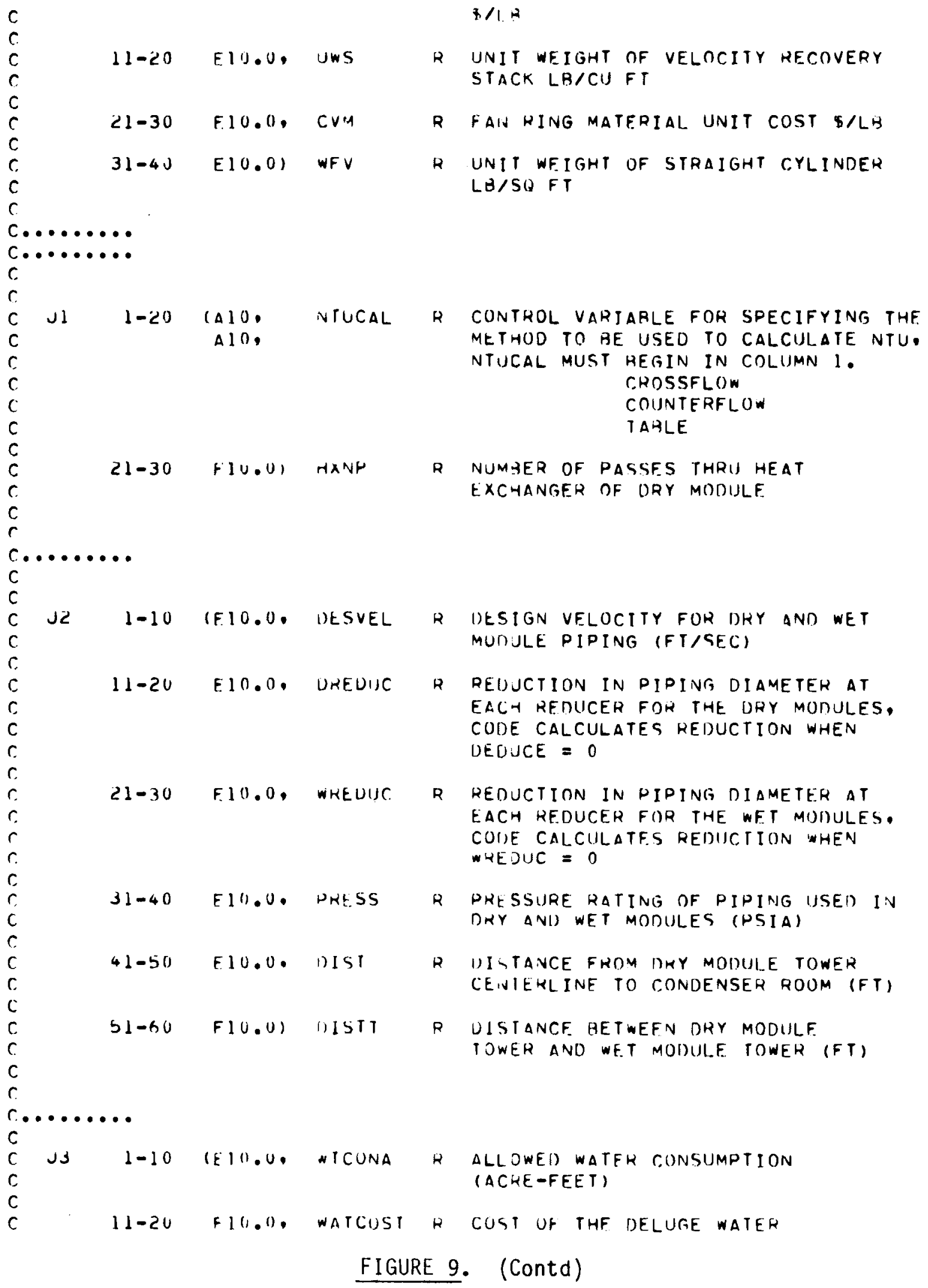




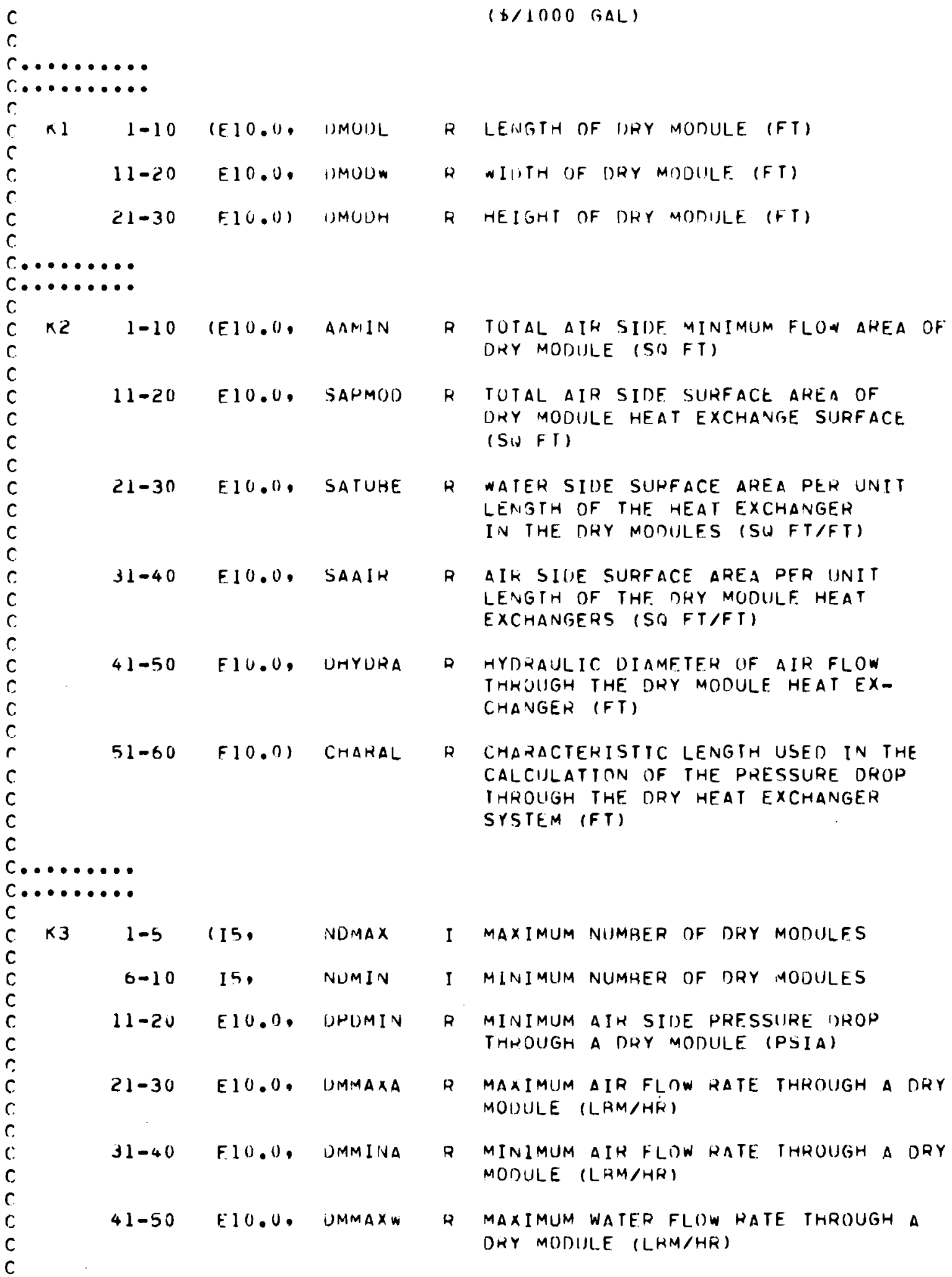

FIGURE 9. (Contd) 


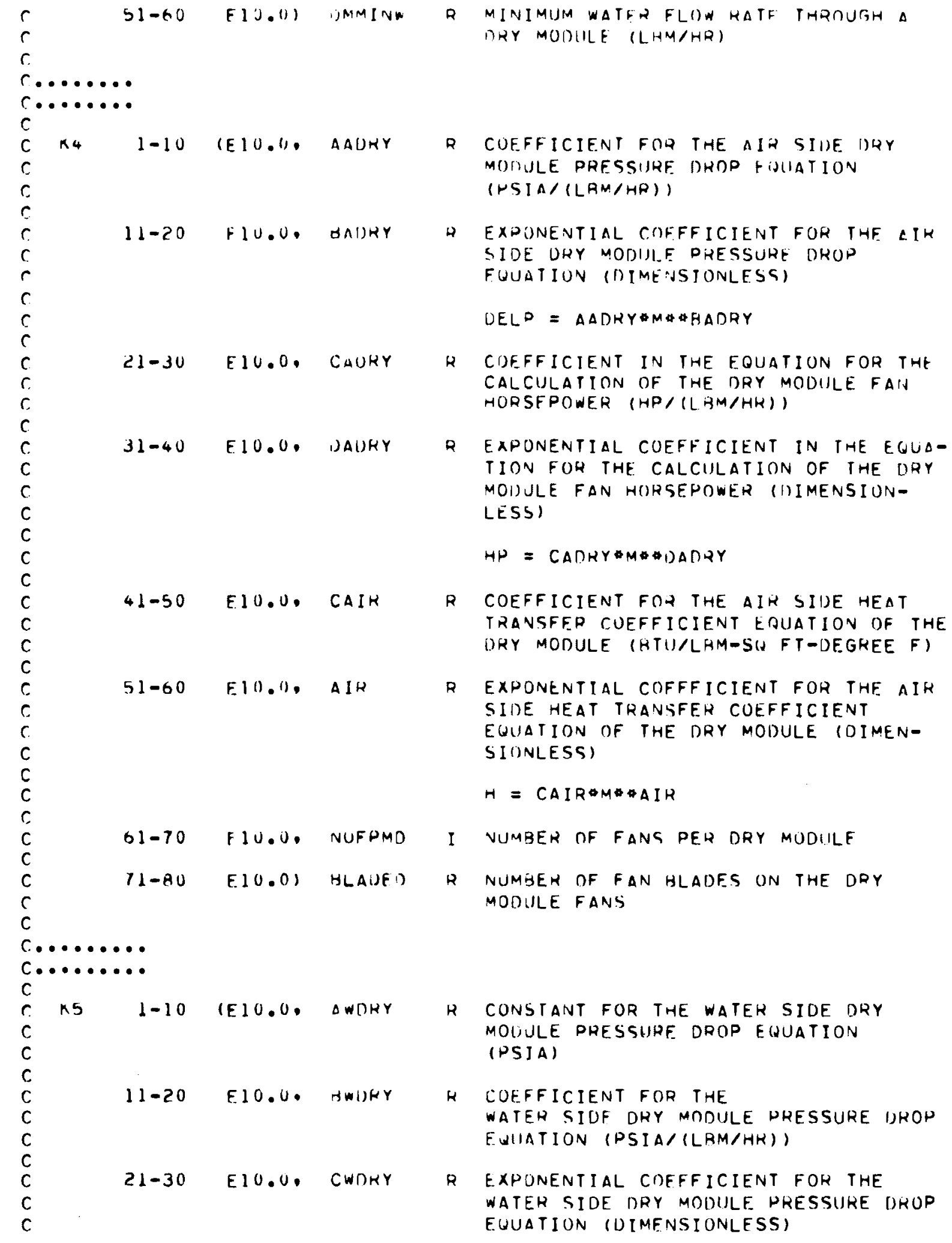

FIGURE 9. (Contd) 


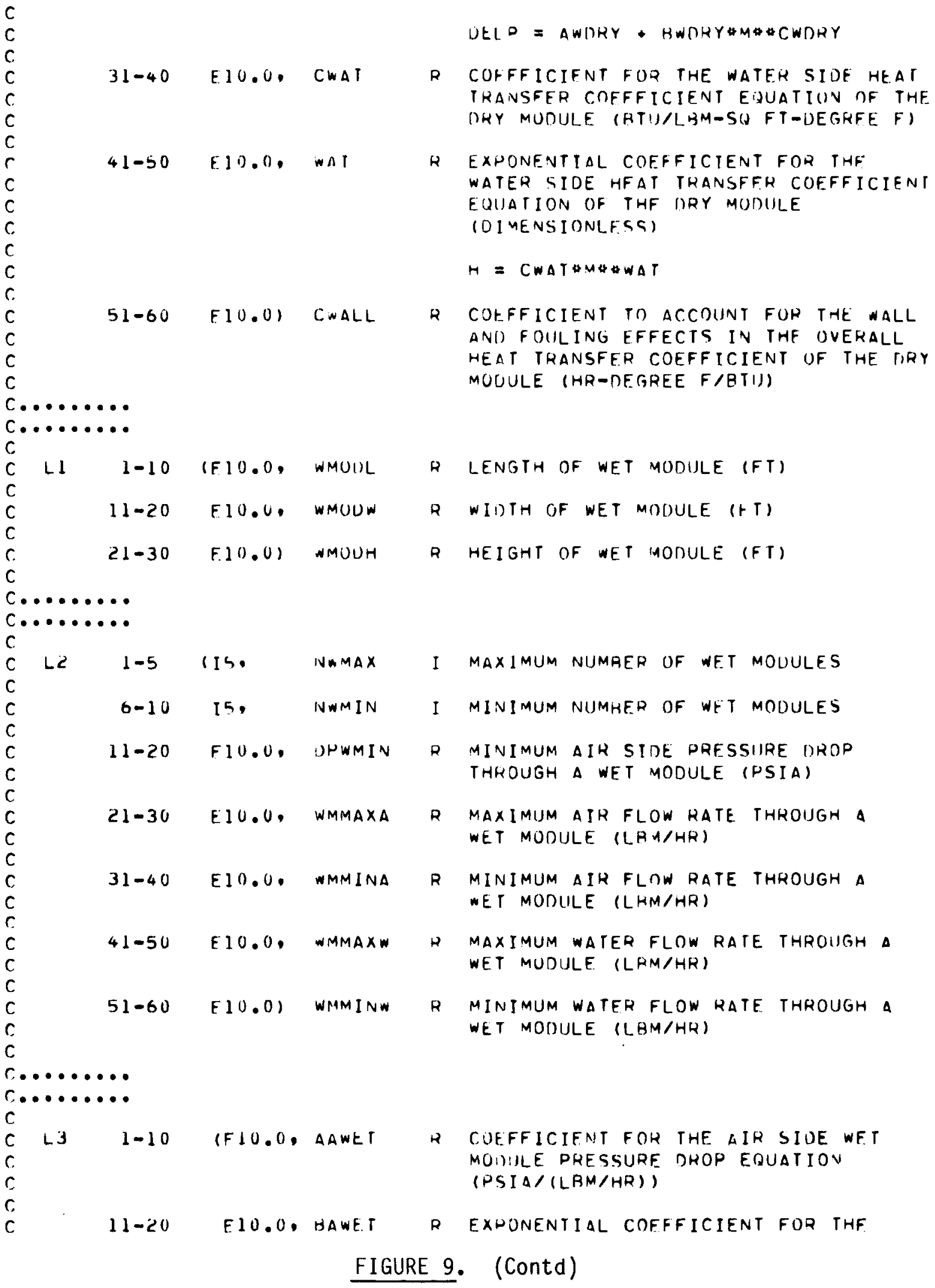




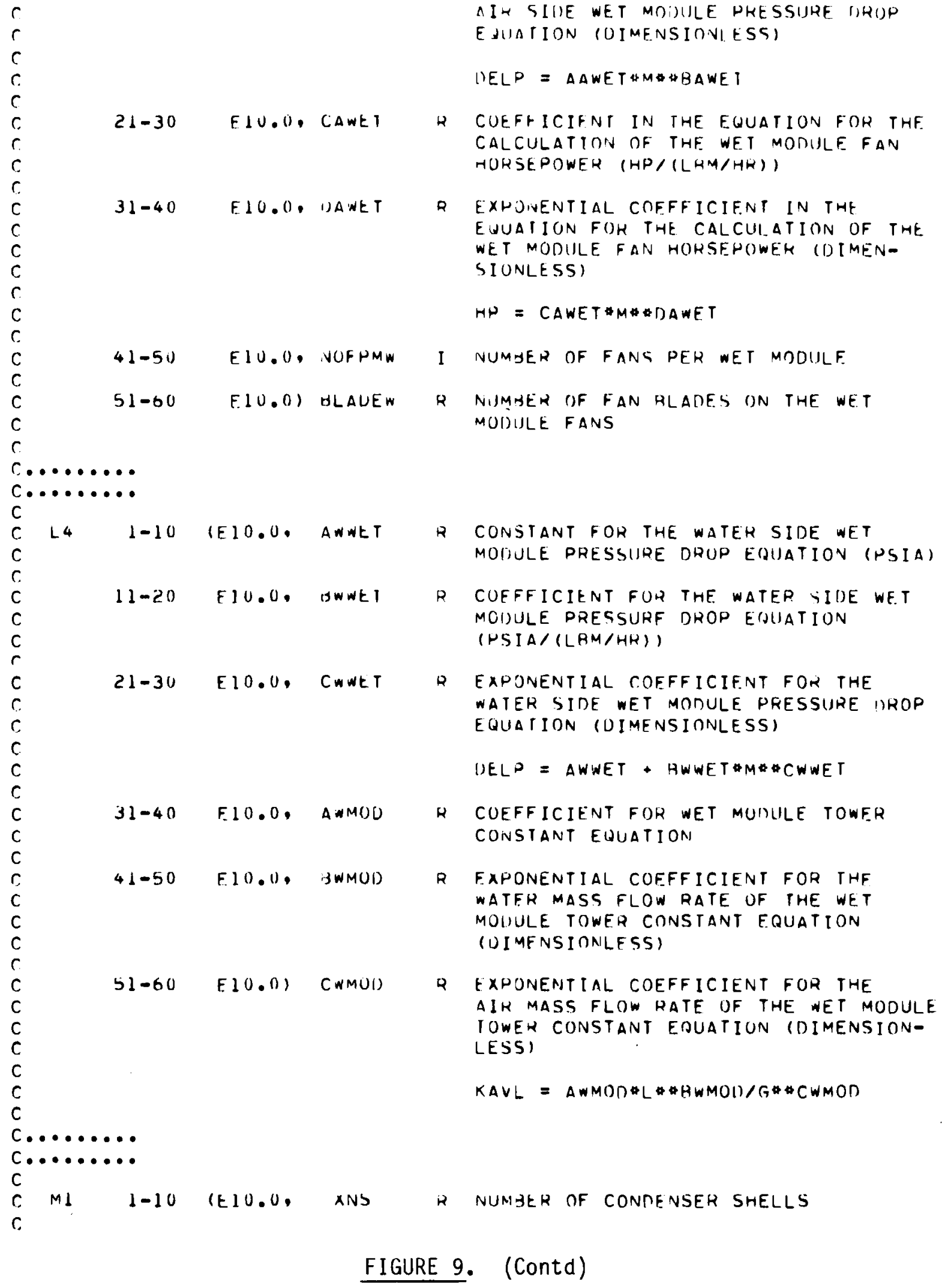




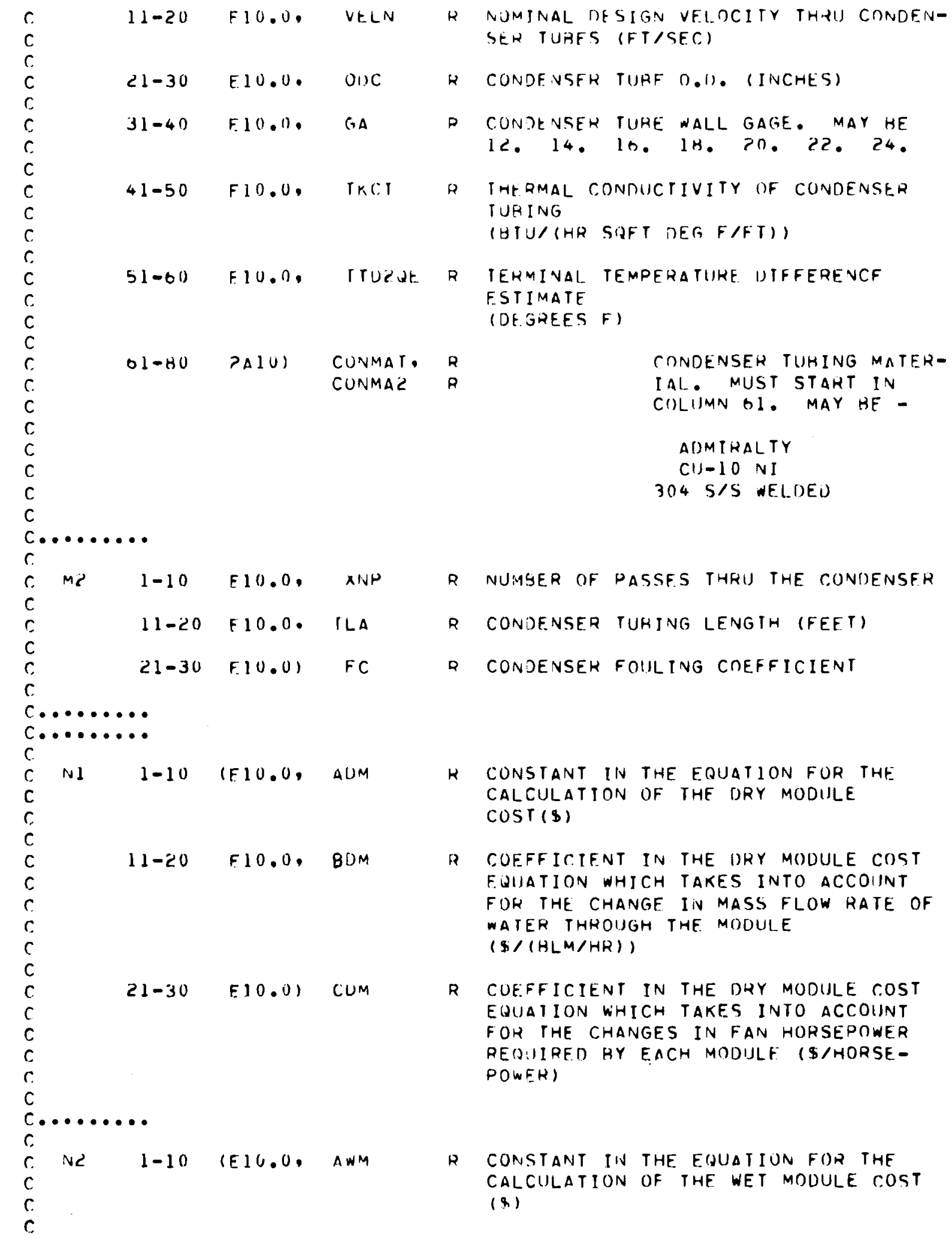

FIGURE 9. (Contd) 


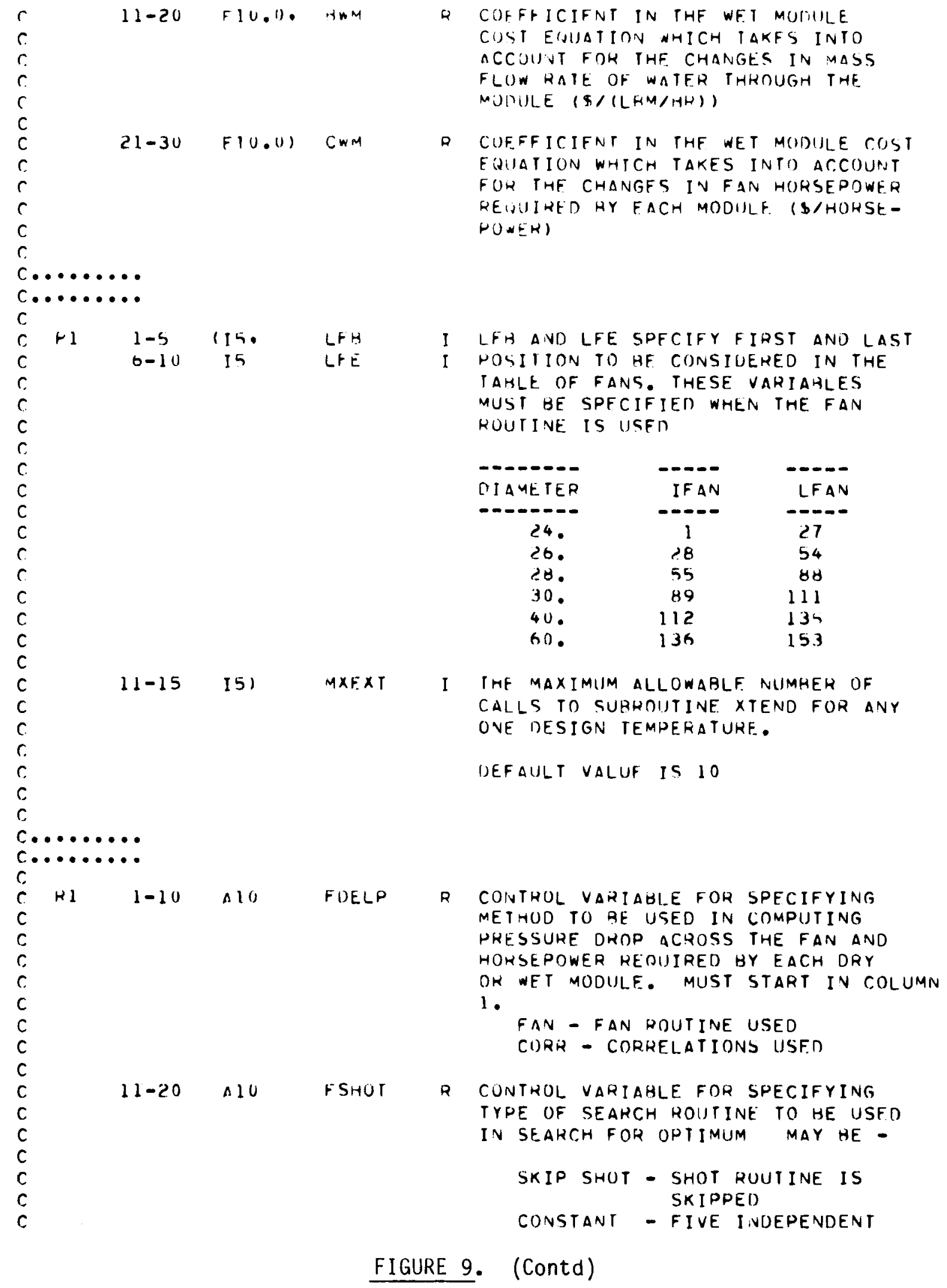




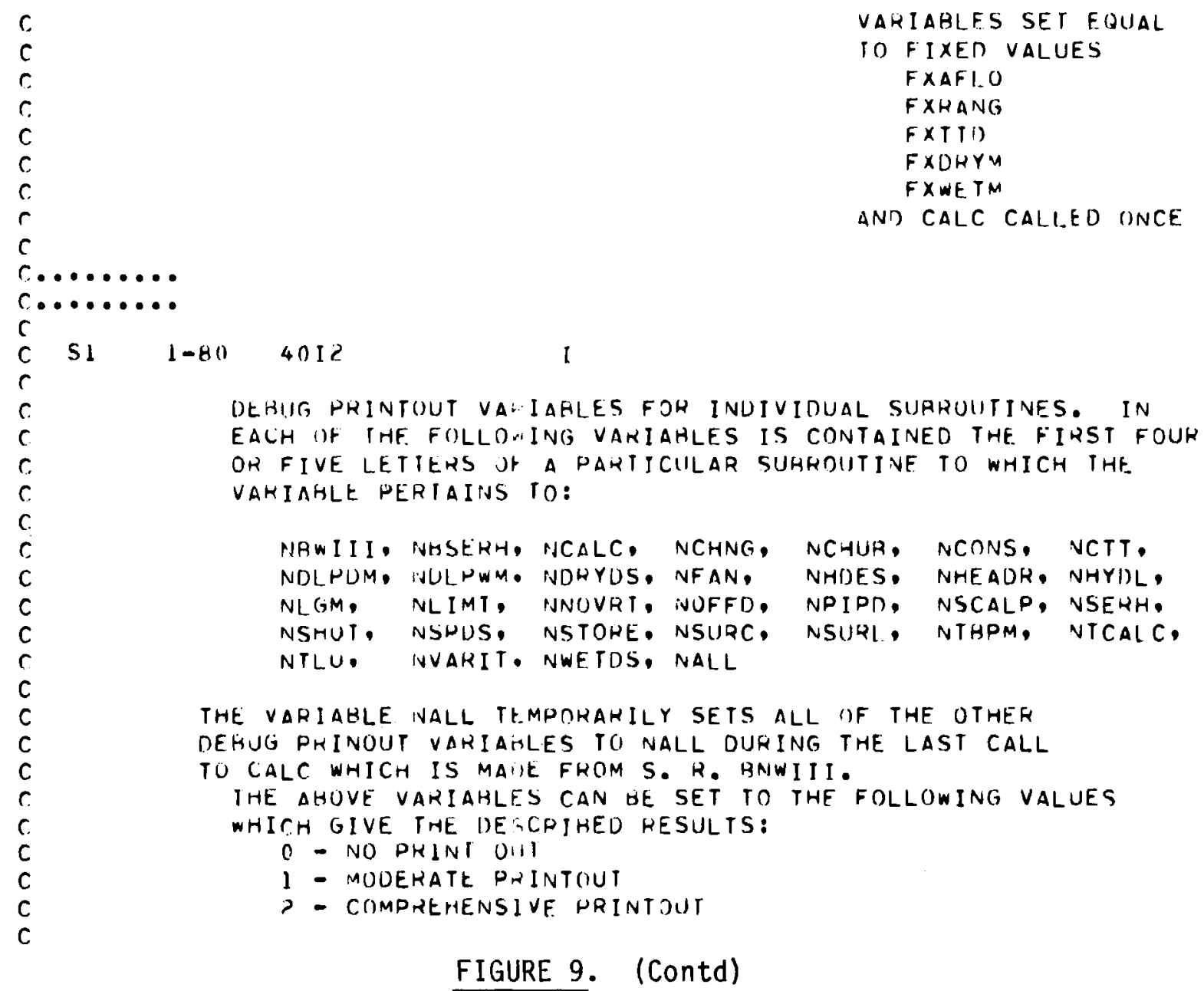

\subsection{MODULAR DRY/WET CODE OUTPUT}

Complete output from a typical run of the modular dry/wet code is shown in Figure 10, which is presented on p. 49 at the end of this discussion. The circled numbers on the figure correspond to the numbers in parenthes is in this section. The output report is divided into the following sections:

(100) through (300) Input summary

(400) through (500) Plant scaling for increased steam and for fans and pumps

(600) Dry module design and performance parameters

(700) Wet module design and performance parameters 
(800) Wet module performance parameters over ambient temperature range

(900) Piping system design for supply and return piping

(1000) Condenser design

(1100) Fan design

(1200) Plant performance as a function of yearly ambient temperature range

(1300) Cost summary

(1400) Operating summary

\section{(100) Output Printed by Subroutine SETUP}

This line begins a card-by-card summary of input data. Any cards preceding the first blank card are printed as title or description cards. After the first blank card the values are printed as they are read, and the variable name is printed immediately below the value. The line tags $A 1$, $B 1$, etc., correspond to the Card Type designations used in the input description presented in Section 5.2. Variable names printed here are defined in the input description section. Every input variable read by the program appears in this summary.

\section{(200) Output Printed by Main Program and Various Subroutines}

TD is the design temperature $\left({ }^{\circ} \mathrm{F}\right)$ used in calculations for this case. The design temperature of the plant is the air temperature at which the power plant and cooling towers are designed to give a net power of PSIZE.

(250) Output printed by various subroutines

Printout between 200 and 300 comes from individual subroutines of the code. The amount of debug printout can be controlled by the user. The majority of the subroutines have debug printout variables whose values are input to the code on card S1. If the variable is set equal to zero, no printout is made from that corresponding subroutine. A value of one or two gives varying degrees of printout. (Warning: one should be careful in setting 
these values. Since this is an optimization code, subroutines are usually called a large number of times, resulting in a large amount of printout.)

(300) Through (330) Output Printed by Subroutine INPSUM

Some of the more frequently changed input parameters are summarized here with more descriptive labels than are given in the preceding summary.

(305) The options summarized here are those selected by the variables FXAFLO, FXRANG, FXTTD, FXDRYM, FXWETM, and TLIM on Card Type B4, and VELREC on Card Type $\mathrm{H} 1$.

(310) The starting point in the search for an optimum is specified by AFLOPM, RANGE, TTD, DRYMOD, and WETMOD. These correspond to the values of $\operatorname{VAS}(1), \operatorname{VAS}(2), \operatorname{VAS}(3), \operatorname{VAS}(4)$, and $\operatorname{VAS}(5)$ on Card Type B1.

(320) Input data pertaining to the steam turbine are summarized here.

(330) Unit costs and costing factors from Card Types D1 and E1 are reported here.

(400) Output Printed by Subroutine OUT2

This report is printed upon return from subroutine SSCALE after the steam supply system is scaled to allow for increased heat rate at the rated back pressure. The term HRFAC1 is the heat rate factor at the rated back pressure, RBP.

(500) Output Printed by Subroutine OUT4

Values reported here are intermediate results after the plant is scaled for increased steam but before it is scaled for fan and pump power requirements. HRFAC2 is the heat rate factor at the indicated design back pressure. PLANC2 is the plant cost; PSIZ12 is the plant size needed at rated back pressure to provide the specified plant power output (PSIZE on Card Type D1) at design back pressure: PSIZ12 = PSIZE* (HRFAC2/HRFAC1). SPBP is the cost differential incurred in scaling the plant to allow for the difference between design conditions and base plant conditions (conventional turbine at rated back pressure). 
(550) Output printed by subroutine OUT4

The information reported here is for the plant after scaling to provide for additional power to drive fans and pumps. The scaling factor, S.F., is the ratio PSIZE/ (PSIZE minus power required by fans and pumps). PSIZ13 corresponds to PSIZE12 above, but now the fan and pump power requirements are included: PSIZ13 = (PSIZ12) $\times($ S.F.). The power PTOTAL is the size of the scaled plant: PTOTAL $=($ PSIZE) $\times$ (S.F.). PLANC3 is the plant cost per kilowatt, excluding fan and pump capital costs, at design conditions. SPC is the differential cost of the plant due to the use of a dry cooling tower as a heat rejection system--it is the difference in cost between the plant using a conventional turbine at rated back pressure and the plant using a nonconventional turbine at plant design conditions.

(600) Dry Module Design Parameters Printed by RRTDRY

This output summarizes the unscaled design point values for the dry modules. It lists the physical dimensions of the dry modules that are input to the code. It also specifies the design point values of the operating parameters of the dry modules.

(700) Wet Module Design Parameters Printed by RPTWET

This output summarizes the unscaled design point values for the wet modules. It lists the physical dimensions of the wet modules that are input to the code. Also listed are some of the design point values of the operating parameters of the wet modules.

(800) Wet Tower Operation Parameters Printed by WETOP

This table of values provides the operational parameters of the wet modules as a function of the ambient temperature range over which the wet modules operate. 
(900) Design and Costing Information for Piping and Pulping Systems Printed by RPTPIP

Design and cost information is provided in this printout for the distribution piping going to both the dry and wet modules. The cost for pipe reducers and tees are recorded. The length and diameter of the pipe are also reported. For the pumping station the costs are broken down into pump, pump electrical, and pump fitting costs.

(1000) CONDENSER Output Printed by Subroutine RPRT2

The condenser design point values and costing values are reported in this section.

(1100) Fan Output Printed by Subroutine RPTFAN

Fan geometry, costs, and design conditions are reported here. Design condition values reported in the column labeled ADJUSTED are for air reduced to standard conditions. The space labeled DRIVE SYSTEM is reserved for future use. In its present form, the model assumes a spiral bevel drive system only.

This output is optional. If the correlation option is selected for FDELP, this printout is bypassed.

(1200) Cooling System Performance Printout by Subroutine VARIT

System performance and costs are reported for one year of operation at times and temperatures specified on Card Types $C 1$ and C2. Abbreviations used in column headings are:

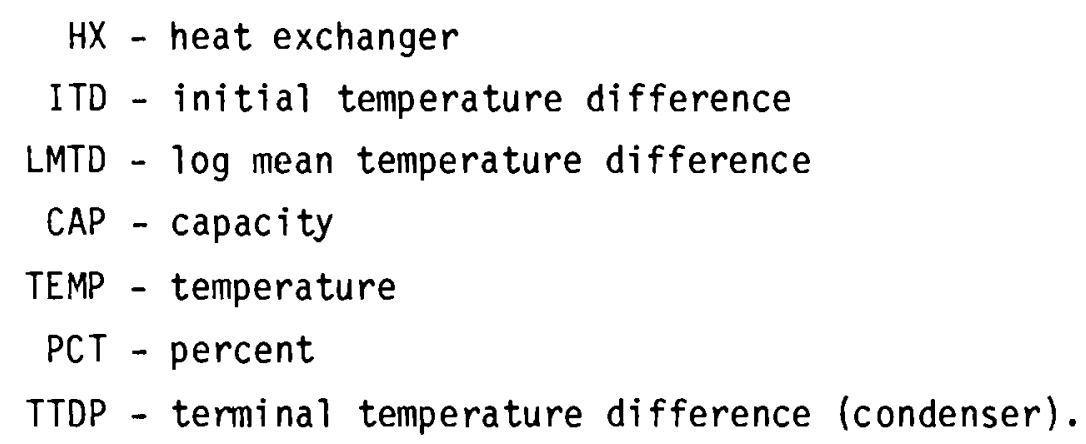


FINAL INCREMENTAL COST is the total of the entries in the PORTION OF INCREMENTAL POWER COST column. Units are mills/kWh. Capacity charge of gas turbine is computed by the expression CAPACITY CHARGE = (CAPCHG) (PSIZE - PGEN), where

PGEN is the power generated at highest ambient temperature (PSIZE-PGEN) is the replacement capacity (KW) CAPCHG is the cost of replacement capacity $(\$ / \mathrm{kW})$ PSIZE and CAPCHG are input values on Card Types D1 and E1.

(1300) Output Printed by Subroutine SUMCOS

Major cost components are summarized here. Costs reported under the heading CAPITAL COST SUMMARY (1310) are in dollars; those reported under UNIT ENERGY COST SUMMARY (1320) are in mills/kWh. The ENERGY PENALTY $(1330)$ is the summation of the products of two columns in the performance cost table (1200), that is, (COST TO REPLACE LOST CAP) $\times$ (PCT TIME AT AMBIENT TEMP). Similarly, the ADDITIONAL BASE PLANT FUEL (1340) is the summation of the products (CHANGE IN FUEL COST) $\times$ (PCT TIME AT AMBIENT TEMPERATURE). OPERATION AND MAINTENANCE unit cost (1350) is based on the cooling system capital cost and the input variable PER (Card Type D1), which is simply the ratio of maintenance cost to capital cost. The calculation is made in subroutine SCALP. The final TOTAL $(1360)$ is the same as the FINAL INCREMENTAL COST reported in the preceding table $(1200)$.

(1400) Summary Output Printed by Subroutine SUMMRY

This section gives an overview of the modular dry/wet cooling system in terms of size, operating parameters, and incremental cost. 
(100)

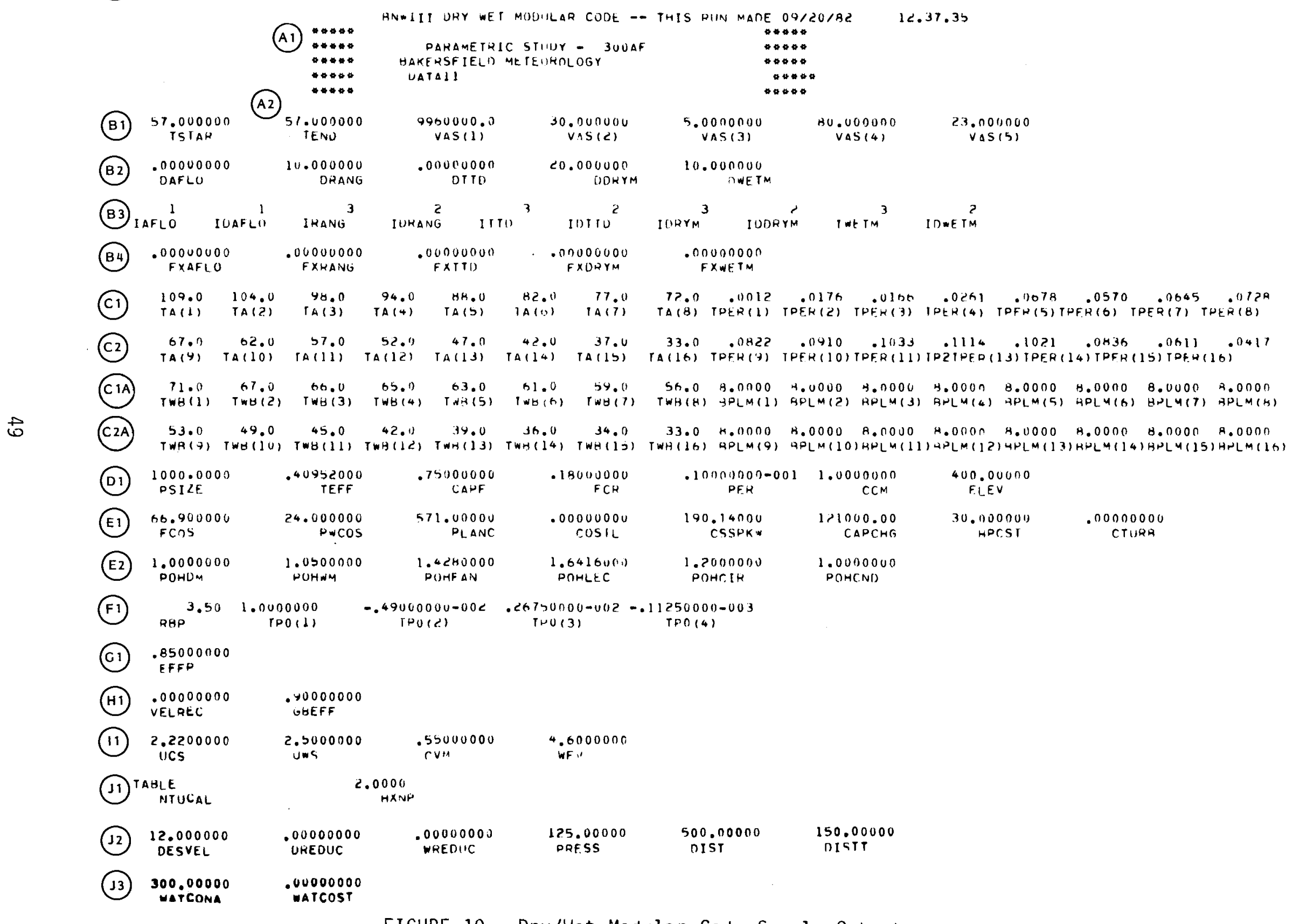

FIGURE 10. Dry/Wet Modular Code Sample Output 


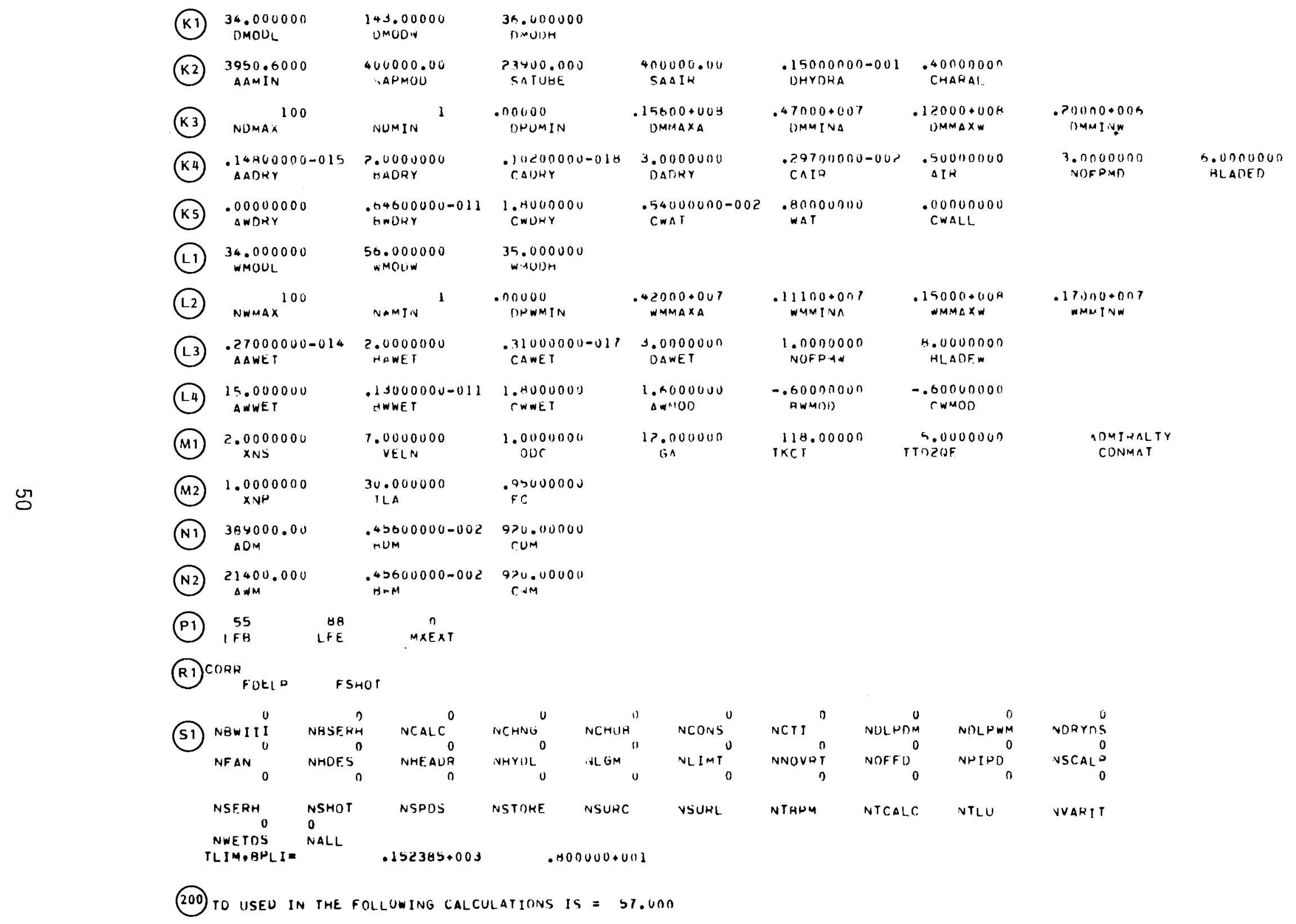

\section{FIGURE 10. (Contd)}




\section{(305)}

WTIONS SELECTEU FOH THIS RIN
OPERATIUNAL MODE SELECTED IS WEI UHY UPPEK LIMIT ON TUKBINE TEMP $132.4 F$ $\triangle I R$ FLOW RATE PEN MOUULE UNCINSTHAINEO RANGE UF WATER IN CUNDENGER UNCOMSTHAI'NEO

TERMINAL TEMPERATURE DIFFERENCF UNCONSTRAINEU

NIIMHEF OF DRY MUIJULES UNCONSTRAIINEU NIMMEEF OF WET MOUULES UNCONSTRAINE. RUN WITHOUT VEI, RLITY RECOVERY
AIL FLUW RATF PEH MONIHEE RANTIE OF WATEN TN COINDENSOH TERMINAL TFMPERATURE DIFFERENCE TIDI $5.000 F$ NIMMER OF DKY MUDULES NUMGEY OF WET MOOHLES
3.
(320)

MEAT RATE FACTOR A) FUINCTION OF haCKPHESSIJHE (INCHFS OF MERCUhY) TUAHINE HATING RACKPAESSURE J.SU INCHES UF ME.RCURY
SITFE ELEVATION

330 UNIT COSIS AND COSIING FACTOHS

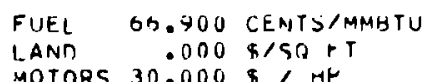

POWER PLANT CONSTRIBCTION REPLACEMENT PUWEH REPLACEMENT CAPACITY CHARGE
$311.000 \times 1 \mathrm{Km}$

24.000 MIILS/KWH

TURHINE DUTPUT $121000.000 \% 140$

\section{COEFFICIENTS FOR DOLYNOMIAL CURVF FI

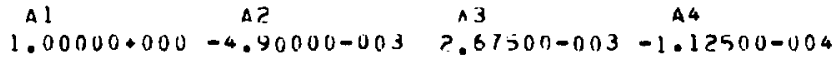

FIXED CHARGE HATF HASE THERMAL EFFICIENCY CONSTRUCTION COSI VIITIPLIED MATT COSTS ICAPITAL COSTS

\section{FIGURE 10. (Contd)}




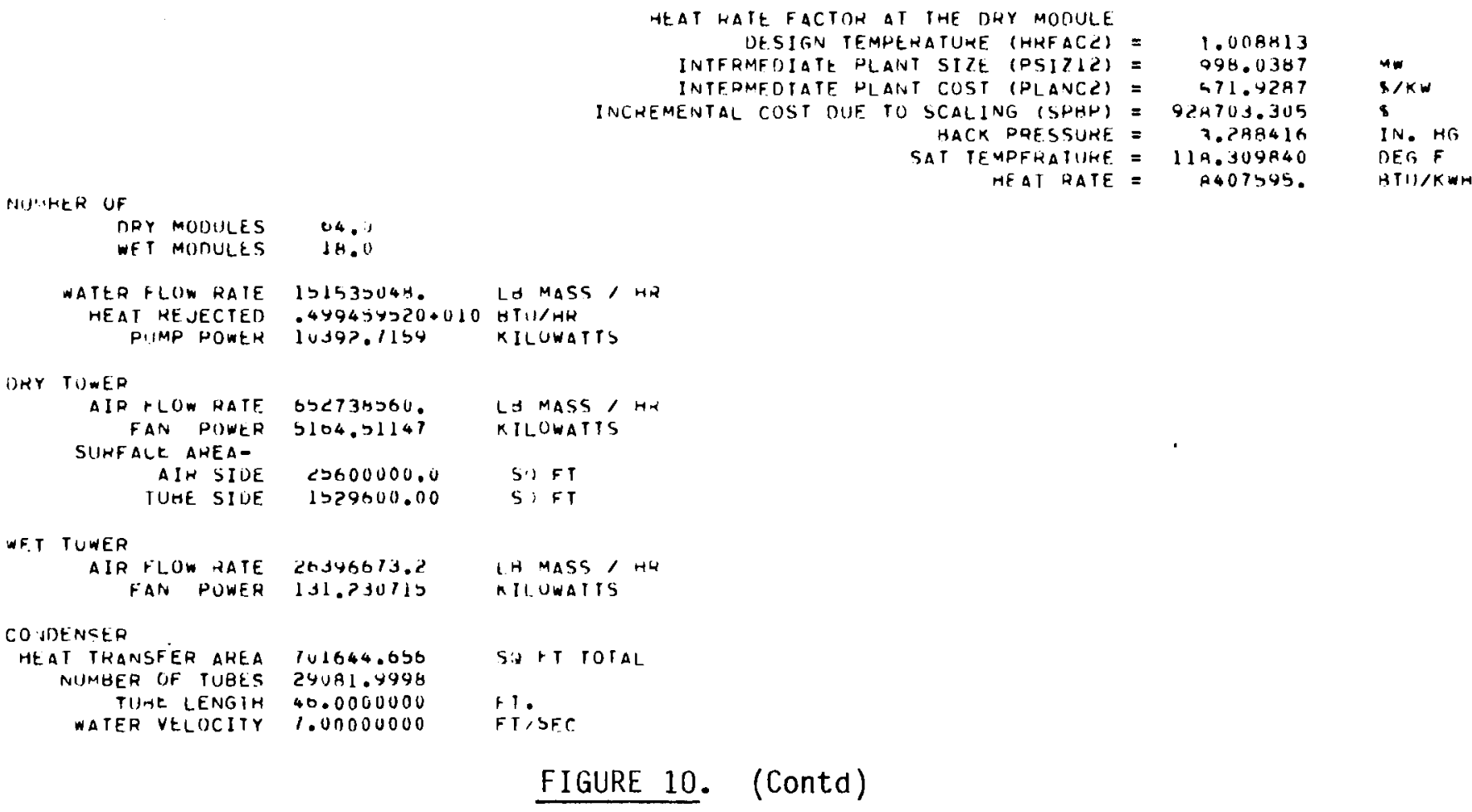

FIGURE 10. (Contd) 
NUPBER OF

$$
\text { THY MOUULES }
$$$$
\text { WET MUOULES }
$$

NATER FLOW RATE IS39?Y766. LA MASS, HY

HEAT KEJECTED PUT3SCSI2+U10 HTW/HR

DHY TOWER

$$
\begin{aligned}
& \text { AIR FLOW RATE OOJ0538J2. L3 MASS, HA } \\
& \text { FAN POWER DC46.120SY KILUWATTS } \\
& \text { SURFACE APEA- } \\
& \text { TUQE SIUE IOS3772.36 SIF }
\end{aligned}
$$

AIR FLOW RATE 2OUI3ACI.7 LA MASS, HN

$$
\text { FAN POWER IJS.30456? KILUWATTS }
$$

CONDENSER

MEAT TRANSFEH AREA TI2732.189

NUMBER OF TUYES 29541.5841

TULE LENGTH 40.0000000

WATER VELOCITY 7.00000000

SCALING FACTUH = 1. N1580307 TUIAL POWF OUTPUT OF THE PLANT $=1000.00000$

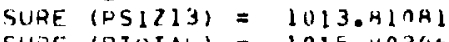

FINAL UNIT PLANT CUST (PLANCS $=1015.40306$

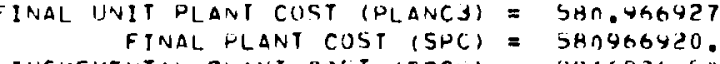
INCHFMEVTAL PLANT COST (SPCU) $=9966926.50^{\circ}$ 
(600)

D h Y MUULE OE S I fon pahameTERS

NUMBEH OF MONUIIES

$$
\text { WENGTH }
$$

04

WIDTH

$34.6 \mathrm{FT}$

NEISHT

$143.0 \mathrm{Fr}$
$36.0 \mathrm{FF}$

SUHFACE ARTA/ MODIIIE

$$
\text { IUAE SIIIE }
$$

AIT SIDE

NUMGEN OF PASSES

$3.3900+004$ Sis FT

..

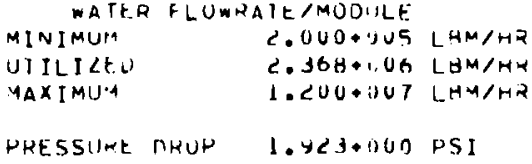

\begin{tabular}{|c|c|c|}
\hline IM & & \\
\hline VIVILIZEO & $1.020+007$ & $L G M / H I D$ \\
\hline MAXIMUM & 1.5600001 & LTM/NP \\
\hline RES & 1 . & 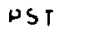 \\
\hline AN HP/MOIJILE. & $1.042+002$ & $4 \pi$ \\
\hline
\end{tabular}

COSTIMOUIJEF

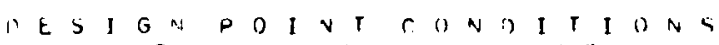

$4.944+1058$

WAIER INLET TEMH IITO TOEG F

WATEKEXITTEMP B3.? TEG F

AIH INIET IEMP ST.O DEG F AIH LXIT TEMH

\begin{tabular}{|c|c|}
\hline WLTFRSIUE & $6.790+100$ \\
\hline AIKSIIIE & $4.4 B 5+000$ \\
\hline JVERALL U & $7.6 B H+0000$ \\
\hline ITU & +000 \\
\hline
\end{tabular}

HE.AT THANSEER COEFFICIENTS

EFPFCITVENESS $5.569-601$

\section{FIGURE 10. (Contd)}


(700) W I MUDULE DESIGN DARANETFRS

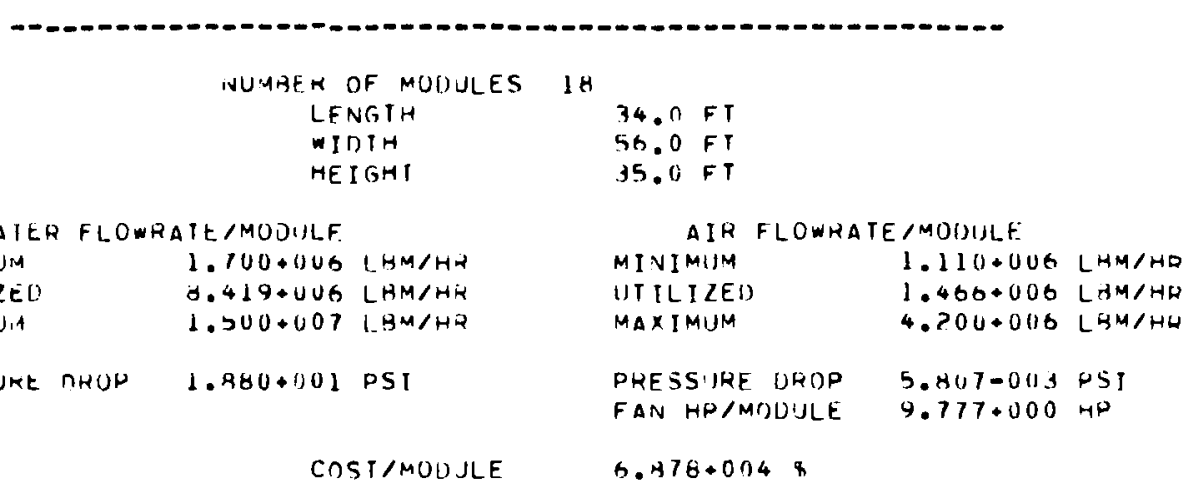

DERFOHAANCE PADAMETEHS

$A T T H E$ I T S I GN D O I N T

KATIY, OF WAIF. IO AIR FLOWRATES

MINIMUM 2.004

$\begin{array}{ll}\text { UTILIIZEO } & 5.741 \\ \text { MAXIMUMM } & 6.2 .30\end{array}$

WET TUWER HEGFOHMANCE

CONSTANT - KAVL .561

COEFFICIENTS UST. IN EWUATIDN FOR TOWER COINSTANT KAVL

CONSTANT OF PRUPOHTIONALTTY 1.600

WATER EXPO WENT

$-.500$

AIR EXPUNENT

. .500

DESIGN POINT CONDITIONS

ATMOSPHERIC PRF.SSUHE

UHY BULA

.985 ATM

104.00 DEG $F$
71.00 DEG $F$

IFMPERATURE WHEHE OPEHATING LINE IS

TANGENT TU SATURATION LINE (TT)

140.53 UEG $F$

ENTHALPY OF SATUQATEO AIR AT TT

218.25 BTU/LBM

FIGURE 10. (Contd) 

NO. TET TEMT OF TEMP OF MIN WATER ENIMALPY ENTHALPY TEMO DRY BULL TEY BILLA

EFFECIIVE RATIII IBF TEMP TEMP OF $\triangle I H A T$ OF AIR OF AIH -NESS UF WATE TO

HEAT FVAD RATE ALT FLITW DEGF DEGF

DF ATH AT OF ATR OF AIR MF T MUDULF. AIL FLD HEJ DER HER HATE DER $109.00-1100$

\begin{tabular}{llll} 
& IJEG & DEGF & 1IEGF \\
\hline 18 & 123.44 & 107.45 & 98.0 \\
16 & 121.74 & 100.44 & 105.3
\end{tabular}

BIUALAM HTU/IAM UEG

36.290125 .14

31.95 111. 1142.91

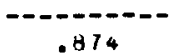

ARUAHR LAM/HR LUMJHQ

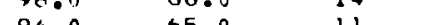

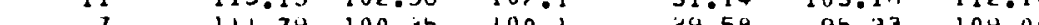

$\begin{array}{ll}98.0 & 63.0 \\ 92.0 & 01.0\end{array}$

100.4500 .35

49.1 $29.58 \quad 95.73 \quad 109.00$

$88 \mathrm{~B}$

$5.7411 .316+0081.113+01151.466+00$ $5.741 \quad 1.289+0081.079 .0051 .466 .0106$ 5.741 1.056.008 0.567 .004104660004

FIGURE 10. (Contd) 


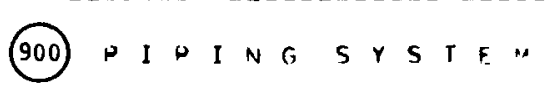

PIPING SYSTEMS DFSIGNED FOR 125. HSIA PHFSSURE

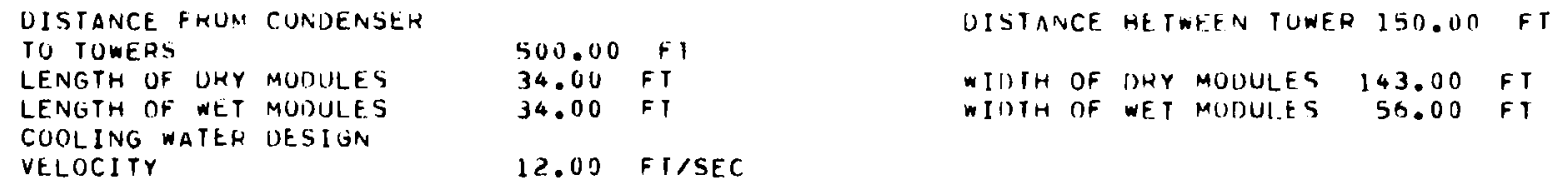

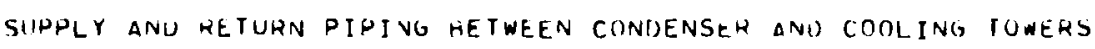

PIPE DIAMETER TU TOWENS

PIPE LENGTH tRUM THE CONUENST.h TO THE TOWFHS SUPPLY AIVU RETURN PIPING COST

PRESSURE URUP

102.00 INCHES

1000.00 FEFT

COSI OF MAIN CIHCULATIUN FLANGES

$1010.00 \$ 210 \% 3$

$151.82 \mathrm{HSF}$

COST OF MAIN CIRCILLAIIOV EXPANSION JOINTS

$51.511 \$ 10 * 4$

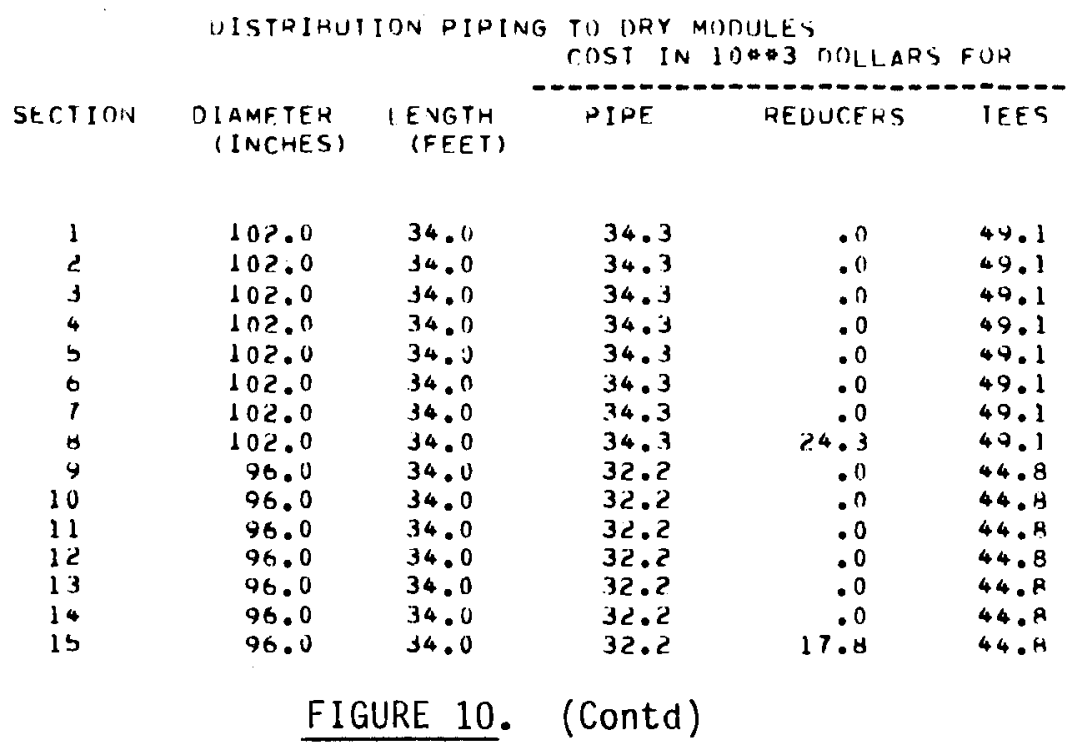




\begin{tabular}{|c|c|c|c|c|}
\hline 90.0 & 34.0 & 30.1 & .0 & 40.5 \\
\hline 90.0 & 34.0 & 30.1 & .0 & 40.5 \\
\hline 90.0 & 34.0 & 30.1 & .11 & 40.5 \\
\hline 90.0 & 34.0 & 30.1 & .0 & 40.5 \\
\hline 90.0 & 14.0 & 30.1 & .0 & 40.5 \\
\hline 90.0 & 34.0 & 30.1 & 15.9 & 40.5 \\
\hline 84.0 & 34.0 & 25.6 & .0 & 31.9 \\
\hline 84.0 & 14.0 & 25.6 & .0 & 31.9 \\
\hline 84.0 & 34.0 & 25.6 & .0 & 31.9 \\
\hline 84.0 & 34.0 & 25.0 & .1 & 31.9 \\
\hline 84.0 & 34.0 & 25.6 & . $n$ & 31.9 \\
\hline 84.0 & 34.0 & 25.6 & 13.4 & 31.9 \\
\hline 78.0 & 34.0 & 20.6 & .0 & 23.3 \\
\hline 78.0 & 34.0 & 20.6 & . 0 & 23.3 \\
\hline $7 \mathrm{H.0}$ & 14.0 & 20.6 & . $n$ & 23.3 \\
\hline 78.0 & 34.0 & $20 . h$ & . 0 & 23.3 \\
\hline 78.0 & 34.0 & 20.6 & .0 & 23.3 \\
\hline 78.0 & 34.0 & 20.6 & $\theta . h$ & 23.3 \\
\hline 72.0 & 34.0 & 19.4 & .0 & 20.6 \\
\hline 72.0 & 34.0 & $1 \nsucc .4$ & .0 & 20.6 \\
\hline 72.0 & 34.0 & 19.4 & .0 & 20.6 \\
\hline 72.0 & 34.0 & 19.4 & . 0 & 201.6 \\
\hline 72.0 & 34.0 & 19.4 & $7 . n$ & 20.6 \\
\hline $6 h .0$ & 34.0 & 18.3 & . 0 & 17.8 \\
\hline $6 h .0$ & 34.0 & 18.3 & .0 & 17.9 \\
\hline Bh. 0 & 34.0 & $1 \mathrm{H} .3$ & .0 & 17.8 \\
\hline क6. 0 & 34.0 & $1 \mathrm{H} .3$ & 0.5 & 17.8 \\
\hline no. o & 34.0 & 17.0 & . & 15.0 \\
\hline 60.0 & 34.0 & 17.0 & 0 & 15.0 \\
\hline 60.0 & 34.9 & 17.0 & . 0 & 15.0 \\
\hline 60.0 & 34.0 & 17.0 & .0 & $15 . n$ \\
\hline 60.0 & 34.0 & 17.0 & 5.6 & 15.0 \\
\hline 54.0 & 34.0 & 14.1 & . 0 & 11.1 \\
\hline 54.0 & 34.0 & 14.1 & .0 & 11.1 \\
\hline 54.0 & 34.0 & 14.1 & 4.? & 11.1 \\
\hline 48.0 & 34.7 & 12.3 & .0 & 5.4 \\
\hline 49.0 & 34.0 & 12.3 & .0 & 5.4 \\
\hline $4 R .0$ & 34.0 & 12.3 & .0 & 5.4 \\
\hline 48.0 & 34.0 & 12.3 & 3.3 & 5.4 \\
\hline 42.0 & 34.0 & 10.5 & .0 & 4.3 \\
\hline 42.0 & 34.0 & 10.5 & .0 & 4.3 \\
\hline 42.0 & 34.11 & 10.5 & 2.4 & 4.3 \\
\hline 36.0 & 34.0 & R. 7 & .0 & 3.3 \\
\hline 36.0 & 34.0 & B. 7 & 1.5 & 3.3 \\
\hline 30.0 & 34.0 & 6.4 & .0 & 2.4 \\
\hline 30.0 & 34.0 & 6.4 & . 6 & 2.4 \\
\hline 24.0 & 34.0 & 5.3 & .0 & 1.8 \\
\hline 24.0 & 34.0 & 5.3 & .5 & 1.8 \\
\hline 18.0 & 34.0 & 4.3 & .0 & 1.0 \\
\hline
\end{tabular}

EUUIVALENT PIHE LENGTH FOR PRESSURF DROP CALCULATIUN COSI OF UISTRIMIJTIOA PIPING TO DFY MODULES

FIGURE 10. (Contd) 
TRAMSFEH PIPES BETWEEN DRY AND WET TOWERS

PIPE DIAMETER GETWEEN TOWFRS

TUIAL PIPE LE IGTH BETWEEN TOWEHS

TOST OF THE DITE

102.0 INCHE

549.0 FEET

PRESSUHE DHOP IN THE PIPE

005.0 \$ 10.0

194.2 PSF

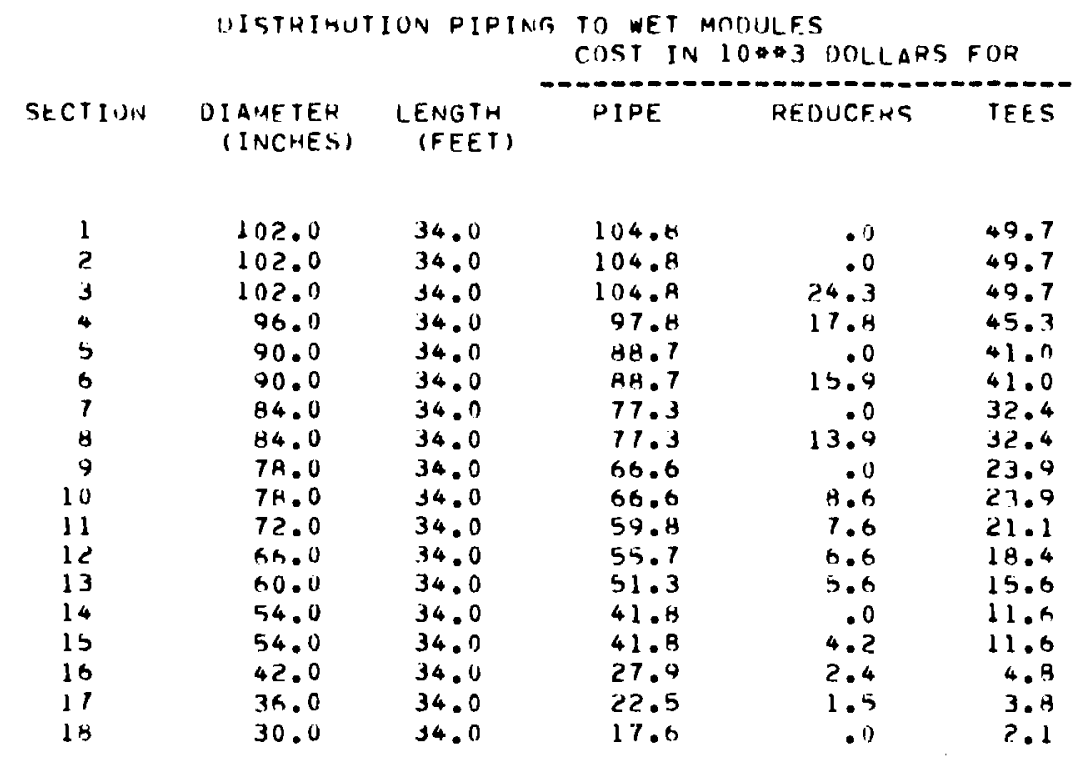

FUUIVALENI PIDE LENGTH FOR PRESSIJRE DHOP CALCILATIUNS COST OF DISTRIAIITION PIPING TO WET MONUIES

$134.0 F T$

$17 \forall 3 . * 10 * 3$

TOTAL SYSTEM PRESSURE JROH

TOTAL PIPING SYSTFM COST

5n95.8 PSF

$\rightarrow 704 . \$ 10 * 3$

FIGURE 10. (Contd) 
950) PUAP STATION

$\begin{array}{ll}\text { IINCSALFO PUMP POWFR } & 10.3927 \mathrm{MW} \\ \text { HUMP COST } & \$ 1979.9 .10 \% 3 \\ \text { PUMP FITIINGS } & \$ 364.0 .10 \% 3 \\ \text { DUMP ELECTRICAL } & \$ 171.1 .10 \% 3\end{array}$

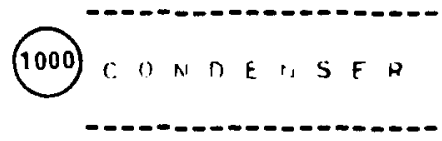

STEAI TEMPEHATURE $11 \% .3$ F

INLET WATEH TEMPEKATURE $93.2 F$

EXIT WATEW TEMPEKATUHE $116.2 \mathrm{~F}$

LOG MEAN TEMPERATUHE DIFFERENCE 11.1 DEG $F$

--- COMDENSER UESCRIPTION ---

NIIMGER OF SHELLS HEAI TRANSFER AHEA PER SHELL. $350+2+0.105011$ NUMHEW OF PASSES PER SHELL TUBE LENGTH 4 H

NUMBER OF TUEES PER SHELL POS41
$171.1 * 10 * 3$
--- DESIGN OPEMAIING CONDTIIONS ---

UVERALI HEAT THANSFER COEFFICIENT 606.06 RTU/HR SU FT DEG F AVEPATE WATER VELOCITY THRU COND $7.0 \mathrm{FT} / S E C$ PRF SSURE DROP IHRU CONDENSER 1540.0 LB/SO FT CONDENSFH EFFECIIVENFS

--- CONDENSER COSTS -..

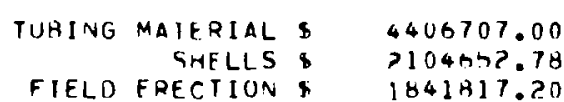

IAOMIRAL TY

FIELD FRECTION \$ 1841AI7.20

TOTAL COST OF CONUENSER GAHS1H?

FIGURE 10. (Contd) 


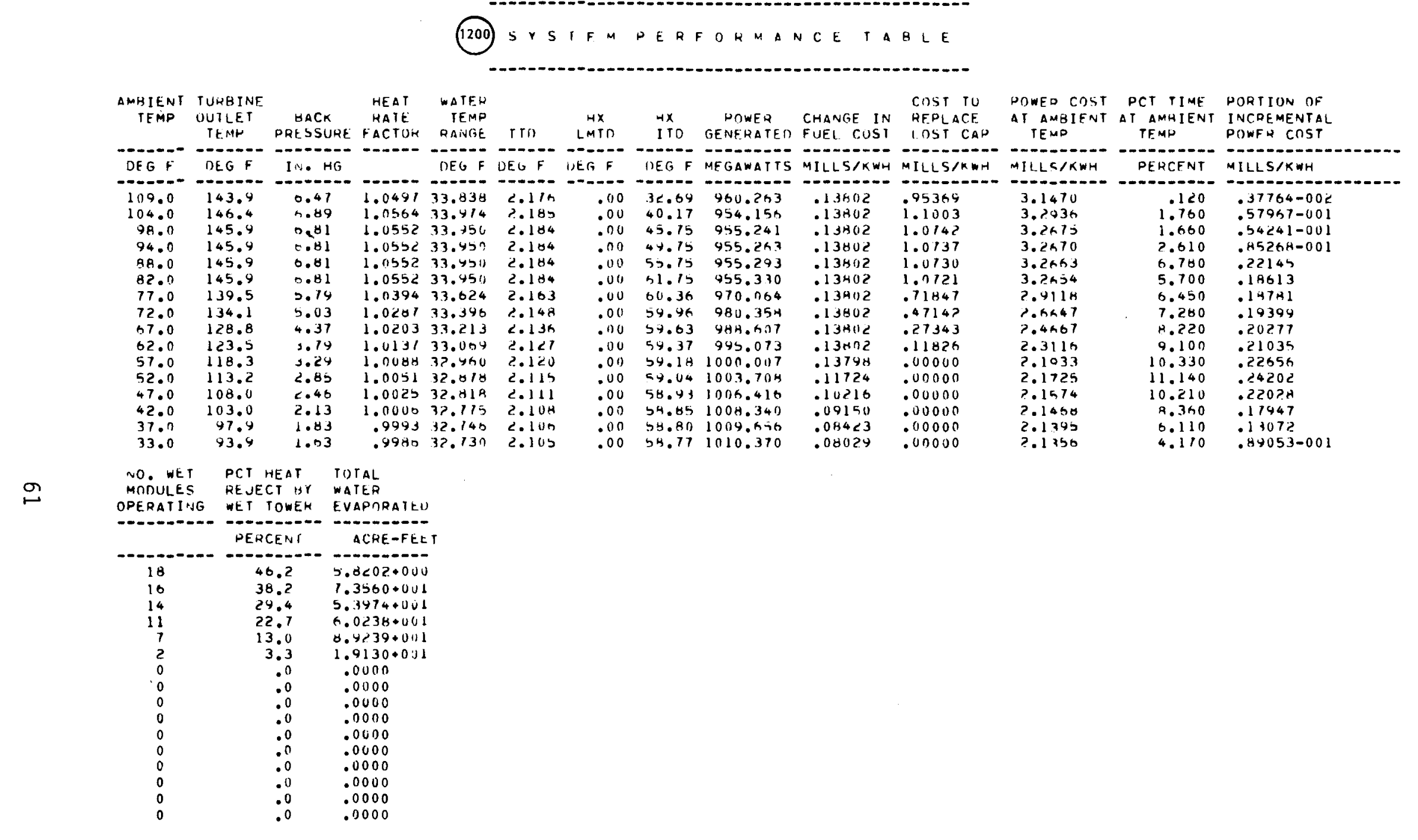

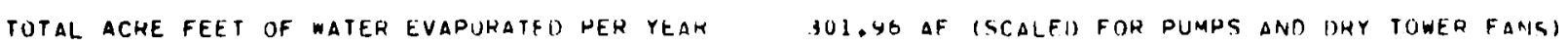

FIVAL INCHEMENTAL COST 2.4919

CAPACITY CHARGE $580 B 212.00$

FIGURE 10. (Contd) 
(1300)

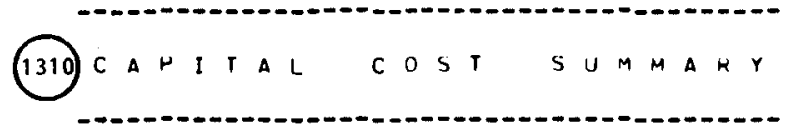

COOL.. ING SYSTEM CAPITAL

URY TUWER
WET TIWEH
PIPING
CONDENSER
CAPACITY PENALTY
PLAN SCALING
STEAM SUNPLY
BASE PLANT
HEAT YATE
FANS ANU DUMPS

온 hrorall.

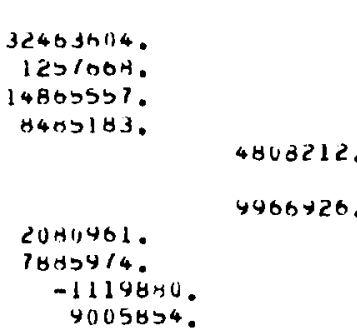

(1320)
WATER

I.AND

rotal capital cost (mater excluUto)

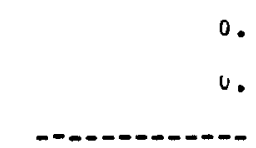

$\$ \quad 71347149$.
0. WATER

.
COOLING, SYSTEM CAPIIAL

$$
\begin{aligned}
& \text { RRY TOWEP } \\
& \text { WET TOWFR } \\
& \text { PIPI VG }
\end{aligned}
$$

CONDFFSEG

CAPACITY PENALTY

- plant scaling

STFAM SUPPL

BASE PLANT

HFAT HATE

FANS ANO HUMUS

(1330) total capital costimater exci noevi

1340. ENEKGYY PENALTY

T350 ADOIIIONal aASE PLant fuel

OPFrRATION and maintenance

(1360) TUtal I INCLUDing water)
COS T SUMMALY

.884414

.4117275

.232471

.131732

.273006

$.570126-001$

.210054

$-.306816-001$

.246736

.000000

-...........

1.96442

.314118

.122454

.868610-001

2.49180

FIGURE 10. (Contd) 


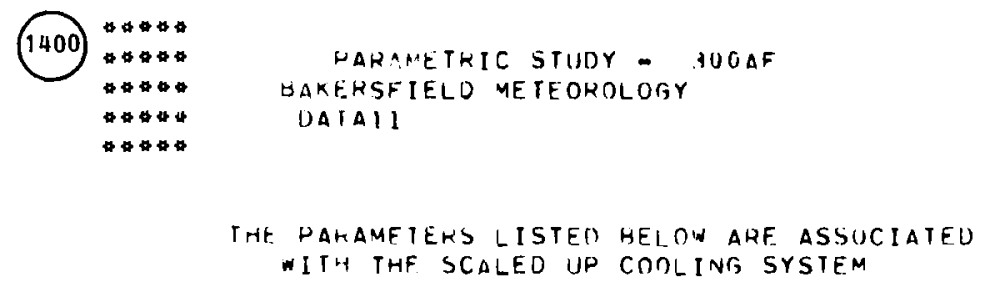

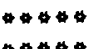

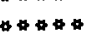

$440 \%$ net module valies

AIR FLON PARAMETEHS AIR FLOW RATE UELTA P, H.X.

r AIN NOWER

r ANS

DO\#W LBM/HR
PSI
MW
NIMHER
IN\#DO LBM/HR
HSI
MW
NIIMHER
FT
HT
FT
1.44 .005 H
8. WATEH FLOW RAIE UELTA P,WATEK Pump POWFE

TOWEH UESIGN

MODULES

MUUULE WIITTH

MOUULE LENGIH

MOUULE HEIGHT

$$
\begin{array}{r}
8.6 \\
19.796 \\
.156
\end{array}
$$$$
14
$$$$
56.0
$$$$
34.5
$$$$
35.6
$$

WATEK PAHAMETERS
COIUENSEH IUESIGN HEAT TRANSFER AREA TIO

perfofmanile patametems UESIG: TAR MAXIMUM THA maximum trip

COSI SIJMMAHY

COOLING SYSTEM
CAPACIIY
STEAM SUPHLY SCALIVG
HEAI HATE SCALING
FAN ANU PIIMP SCALING
ENERGY
HASE FUEL
OAND M
WATEK
INCK. COSI OF COOLING

DHY MODLLE VALIJES
AIR FLOW HAHAMETERS
IO\#\#K LBM/HR $\quad 10.36$

NS

NUMARER

FAN DOWER

FANS

WATER PARA HE TEKS

WATER FLOW RATE

DELTA P.WATEK

PIJMP POWFR

10ษ०の LคM/HR

PS

Mw

TOWEL DESIGN

MUDULES

MODILE LENSTH

MODULE HFIGHI

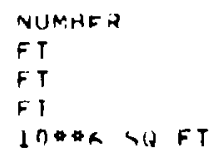

MOOULE WIDTH

HEAT TRANSFER AREA

FIGURE 10. (Contd)

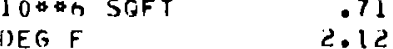

IN HG

IN HG

0.47

460.3

$\begin{array}{lr}\text { MILLS/KWH } & 1.504 \\ \text { MILLS/KWH } & .132 \\ \text { MILLS/KWH } & .057 \\ \text { MILLS/KWH } & -.031 \\ \text { MILLS/KWH } & .047 \\ \text { MILLS/KWH } & .314 \\ \text { MILLS/KWH } & .122 \\ \text { MILLS/KWH } & .087 \\ \text { MILLS/KWH } & .000 \\ \text { MILLS/KWH } & 2.492\end{array}$

143.0

34.5

.400

.0154

102.

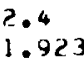

.923

.005

0
5
6
400




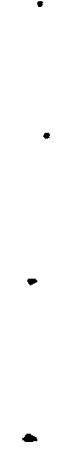




\subsection{SAMPLE PARAMETRIC STUDY}

This section presents a brief parameteric study to illustrate what the code can do and how the required inputs might be prepared.

\subsection{SAMPLE INPUTS}

The inputs for the study are summarized on Tables 2 through 5. A 1000-MWe, fossil-fueled plant located at Bakersfield, California was selected for this study (Table 2). The plant is equipped with a modified conventional turbine capable of operating at a back pressure of up to $8.0 \mathrm{in}$. $\mathrm{Hg}$. The cost parameters are similar to those used in earlier studies under the Dry Cooling Enhancement program and are in 1976 prices to be consistent with the cost algorithms used by the code.

The Bakersfield meteorology was described in terms of 16 temperature intervals, each with its associated dry and wet bulb temperatures and the fraction of the year during which these temperatures exist (Table 3 ).

The dry module characteristics are presented in Table 4. These were synthesized from runs made with the BNW-I SOA (Braun et al. 1977) and the BNW-II (Braun et al. 1978) rectilinear codes. The BNW-I SOA code optimizes a conventional water-cooled condenser system with circular all-dry-cooled towers. The BNW-II code optimizes an air-cooled intermediate ammonia loop system with an al1-dry rectangular tower. The rectangular tower designed by BNW-II was arbitrarily divided up into 50 modules. The modules were $34 \mathrm{ft}$ long, $143 \mathrm{ft}$ wide, and $36 \mathrm{ft}$ high. Each module had three 28-ft-diameter, 6-blade fans with velocity recovery stacks. The minimum air flow rate was based on the validity of the heat transfer correlation at low Reynolds numbers; the maximum air flow rate was based on fan pressure drop considerations. The minimum water flow rate was based on the critical Reynolds number; the maximum water flow rate was based on a corrosion-erosion limit of $12 \mathrm{ft} / \mathrm{sec}$. Tube-side and air-side pressure drop and heat transfer relations were developed in terms of flow rate per module using the equations consistant with accepted correlations. The cost of a bundle was expressed as constant plus two add-ons. The first was an add-on proportional to water flow rate to account for increased piping costs within 
TABLE 2. Design Basis Parameters

Parameters

Values

Plant Parameters

Plant Type Fossil

Design Net Power

Modified Conventional Turbine(a)

Nominal Heat Rejection

Capacity Factor

1000 MWe

$5.01 \times 10^{9} \mathrm{Btu} / \mathrm{hr}$

0.75

Cost Parameters

Fixed Charge Rate

0.180

Fuel $66.9 \$ / 10^{6} \mathrm{Btu}$

Base Plant Capital

$\$ 571 / \mathrm{kWe}$

Base Plant Steam Supply System

$\$ 190 / \mathrm{kWe}$

Gas Turbine Capital

$\$ 121 / \mathrm{kWe}$

Power Cost for Gas Turbines

$24.0 \mathrm{mill} / \mathrm{kWh}$

Design Parameters

Cooling System Type

Indirect mechanical draft wet and

flow parallel air flow)

Tower Configuration

dry cooling towers (series water

Velocity Recovery Stacks

rectangular

Distance from Condenser to Tower

Yes

Condenser Type

2-shell surface condenser

$500 \mathrm{ft}$

Single-pressure, two-pass,

Condenser Tubes

Admiralty, 1.00-in. 00, 12 gage

(a) The heat rate (Btu/kWh) is given by the relationship $8333(1.0-0.049$ $T B P+2.675 E-3 T^{T B 2}+1.125 E-4 T B P 3$ ) where TBP (turbine back pressure) is in in. $\mathrm{Hg}$. 


\begin{tabular}{|c|c|c|}
\hline $\begin{array}{l}\text { Dry Bulb } \\
\text { Temperature, }{ }^{\circ} \mathrm{F} \\
\end{array}$ & $\begin{array}{c}\text { Wet Bulb } \\
\text { Temperature, }{ }^{\circ} \mathrm{F} \\
\end{array}$ & $\begin{array}{c}\text { Fraction of } \\
\text { Year } \\
\end{array}$ \\
\hline 109 & 71 & 0.0012 \\
\hline 104 & 67 & 0.0176 \\
\hline 98 & 66 & 0.0166 \\
\hline 94 & 65 & 0.0261 \\
\hline 88 & 63 & 0.0678 \\
\hline 82 & 61 & 0.0570 \\
\hline 77 & 59 & 0.0645 \\
\hline 72 & 56 & 0.0728 \\
\hline 67 & 53 & 0.0822 \\
\hline 62 & 49 & 0.0910 \\
\hline 57 & 45 & 0.1033 \\
\hline 52 & 42 & $0.11: 4$ \\
\hline 47 & 39 & $0.12 ? 1$ \\
\hline 42 & 36 & 0.0836 \\
\hline 37 & 34 & 0.0611 \\
\hline 33 & 33 & 0.0417 \\
\hline
\end{tabular}

(a) Site elevation is 400 feet above mean sea level. 


\section{TABLE 4. Dry Module Characteristics}

Characteristics, units

Length, ft

Width, ft

Height, ft

Heat Transfer Area

Tubeside, $\mathrm{ft}^{2}$

Airside

Fans/module

Blades/fan

Air flowrate(a)

Minimum, $10^{6} \mathrm{lbm} / \mathrm{hr}$

Nominal, $10^{6} \mathrm{lbm} / \mathrm{hr}$

Maximum, $10^{6} \mathrm{lbm} / \mathrm{hr}$

Water flowrate (a)

Minimum, $10^{6} \mathrm{lbm} / \mathrm{hr}$

Nomina 1, $10^{6} 1 \mathrm{bm} / \mathrm{hr}$

Maximum, $10^{6} 1 \mathrm{bm} / \mathrm{hr}$
Values

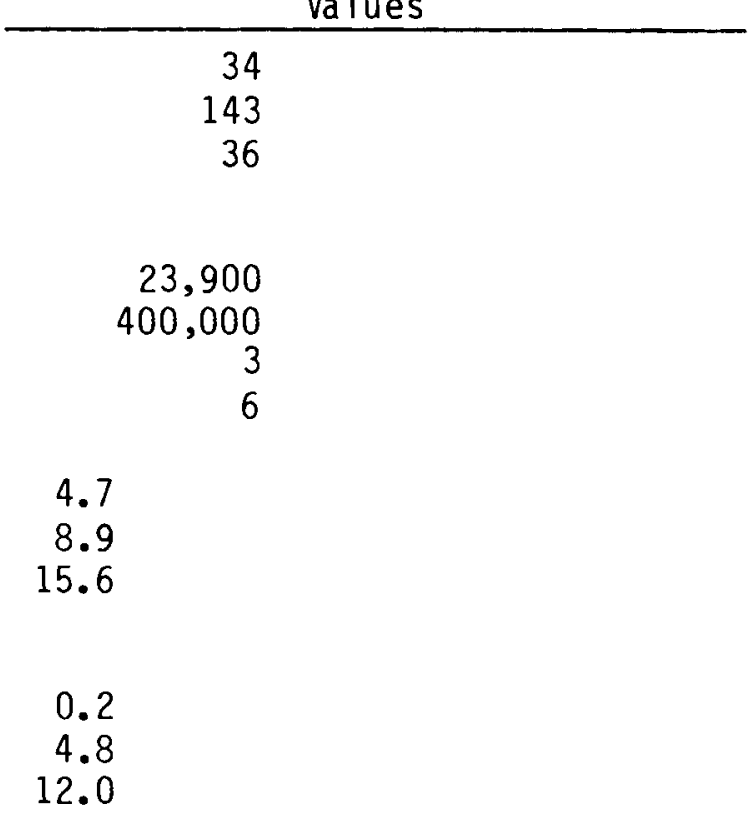

Equations:

Tubeside heat

transfer coefficient,

$h_{W}=0.54 E-2 m_{W} 0.8$

Btu/ft ${ }^{2}-h r-{ }^{\circ} \mathrm{F}$

Airside heat transfer coefficient,

$$
h_{a}=0.297 E-2 m_{a} 0.5
$$
Btu/ft ${ }^{2}-h r-{ }^{\circ} \mathrm{F}$

Pressure drop

water, psi

air, psi

$\Delta P_{w}=0.646 E-11 \mathrm{~m}_{\mathrm{w}} 1.8$
$\Delta \mathrm{P}_{\mathrm{a}}=0.148 \mathrm{E}-15 \mathrm{~m}_{\mathrm{a}}$

Fan power-hp

$P_{f}=0.102 E-18 \mathrm{ma}^{3}$

Cost, $\$ /$ module

Cost $=38900+0.456 E-2 m_{W}+920 P_{f}$

(a) Flow rate units are $1 \mathrm{bm} / \mathrm{hr}$-bundle. 
TABLE 5. Wet Module Characteristics

\section{Characteristics, units}

Length, ft

Width, ft

Height, ft

Fans/module

Blades/fan

Air flowrate(a)

Minimum, $106 \mathrm{lbm} / \mathrm{hr}$

Nominal, $106 \mathrm{lbm} / \mathrm{hr}$

Maximum, $10^{6} \mathrm{lbm} / \mathrm{hr}$

Water flowrate (a)

Minimum, $10^{6} \mathrm{ibm} / \mathrm{hr}$

Nominal, $10^{6} \mathrm{lbm} / \mathrm{hr}$

Maximum, $10^{6} \mathrm{lbm} / \mathrm{hr}$
Values

34

56

35

1

8

1.1

3.3

4.2

1.7

5.0

15.0

Equations :

Pressure drop

air, psi

water, psi

$$
\begin{aligned}
& \Delta P_{a}=2.7 E-15 m_{a} 2 \\
& \Delta P_{w}=15.0+1.3 E-12 m_{w} 1.8 \\
& P_{f}=3.1 E-18 \mathrm{~m}_{a} 3 \\
& K A V L=1.6 m_{a}-0.6 / m_{w}-0.6 \\
& \text { Cost }=21400+4.56 E-3 m_{w}+920 P_{f}
\end{aligned}
$$

Fan power, hp

Tower Constant (KAV/L)

Cost $\$ /$ modure

(a) Flow rate units are $1 \mathrm{bm} / \mathrm{hr}$-bundle.

the bundle. The second add-on was proportional to fan horsepower to account for the increased motor and gear box size and the associated in-plant electrical system to supply power.

The wet module characteristics are presented in Table 5. These were synthesized from a design developed for an earlier study under the DCE program (Fryer et al. 1976) and from consulting the Marley publication "Managing Waste Heat and the Water Cooling Tower" (Dickey 1978). The module was $34 \mathrm{ft}$ long, $56 \mathrm{ft}$ wide, and $35 \mathrm{ft}$ high (to the top of the packing). Each module was equipped with a 26-ft-diameter, 8-blade fan. The minimum and maximum air flow rates were based on an estimate of poor water distribution at low flows and an 
upper limit on fan pressure drop, respectively. Water flow rate limits were based on flow maldistribution and flooding. As with the dry modules, equations were developed for air and water pressure and for fan power as a function of flow rate per module. The tower constant was expressed in terms of total air and water flow taken to the -0.6 power as recommended by the Cooling Tower Institute (1967). As with the dry tower modules, the module cost was expressed as a constant plus an add-on for internal piping as a function of water flow rate and an add-on proportional to fan power for gear box and electrical system costs. This latter coefficient was kept the same for both the dry and the wet modules.

\subsection{SAMPLE RESULTS}

Figure 11 and Table 6 give the results of a parametric study of the effects of water availability on incremental cost. The maximum water availability studied, 5000 acre-ft, is about 50\% wet-dry. As expected, the incremental cost falls with increasing water availability for zero-cost water and rises with increasing water cost for a given amount of water (Figure 11). For nonzero water cost, the cost of water is a constant add-on for a given acrefoot allocation since the BNW-III code forces a plant design that uses up all the water. As a result, the plant designs do not change with increasing water cost for a given water allocation. The increasing incremental cost with increasing water allocation at $\$ 6$ per 1000 gallons merely shows that increased water cost coupled with increasing water use more than offsets the savings in heat rejection system costs. The nearly constant incremental cost exhibited for the $\$ 3$ per 1000 gallons case between 1500 and 5000 acre-ft shows that the increasing cost of water pretty well offsets the savings in plant operating and capital costs resulting from the availability of more water.

Before discussing the differences in the heat rejection systems and operating behaviors shown in Figure 11, it should be pointed out that many of those differences could be illusory. Care should be exercised in drawing conclusions about the differences among the plant designs shown in Table 6 . The reason for this is that many local optimums exist that have very nearly the same incremental costs though the plant designs differ markedly (in the number 


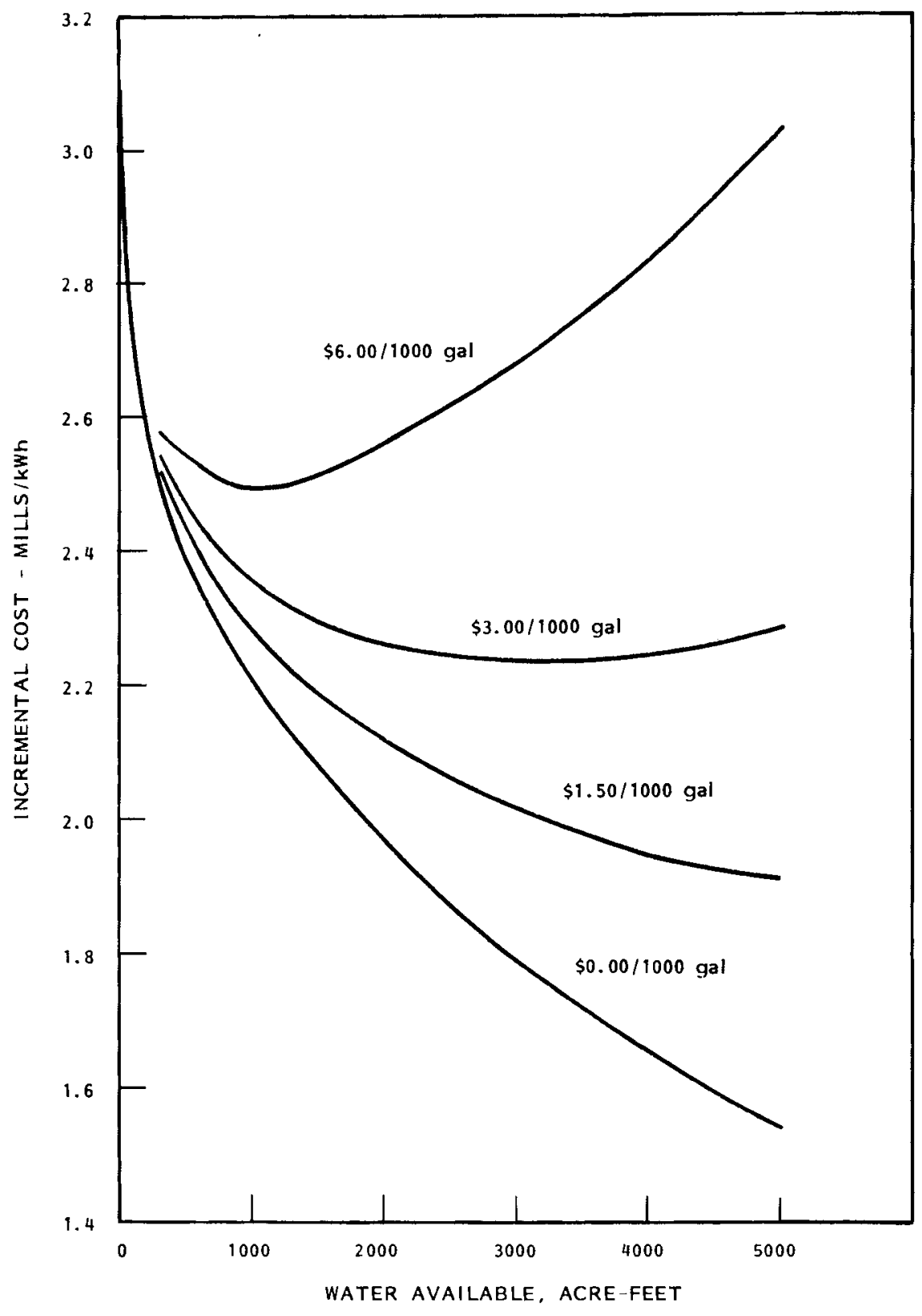

FIGURE 11. Effects of Water Availability and Cost on Incremental Plant Cost 
TABLE 6. Optimum Designs at Different Water Availabilities

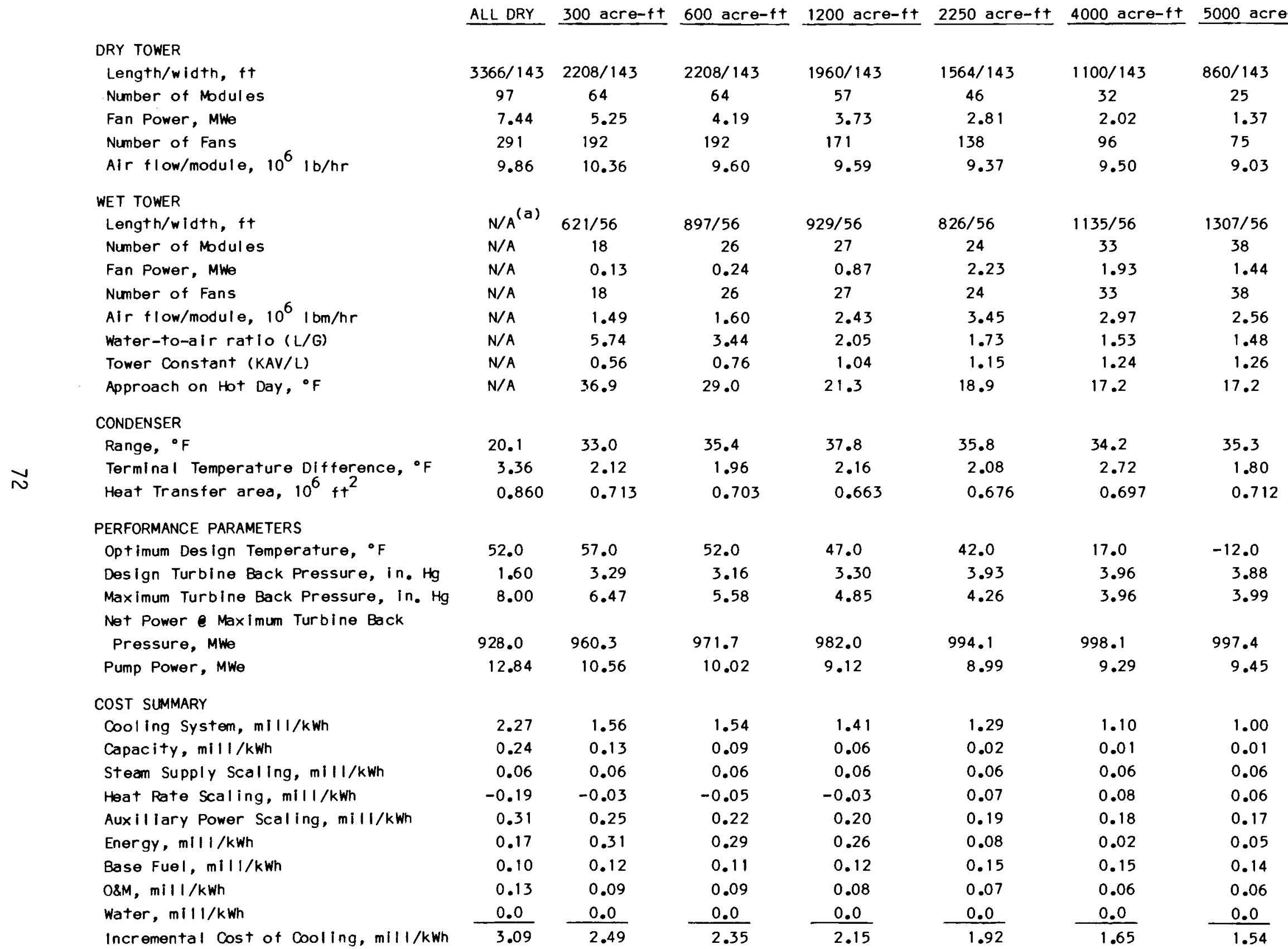

(a) $N / A=$ not applicable. 
of wet and dry modules used, the water range, condenser TTD, air flow through the wet and dry towers, and the like). One can change several aspects of a design and still obtain very nearly the same incremental cost if the remainder of the system is reoptimized.

With this in mind, Table 6 can be reviewed. With the exception of the 600-acre-ft case, the number of dry modules falls with increasing water availability. Air flows per module are all slightly above the nominal value of 8.9 million $\mathrm{ft}^{3} / \mathrm{hr}$-module value. As a result, the dry tower fan power falls as the number of dry modules falls.

With the exception of 2250-acre-ft case, the number of wet modules increases with water availability. The air flow per wet module varies more than the air flow per dry module. Note the high fan power at 2250 acre-ft, which, at 24 modules, exceeds that for 5000 acre-ft with 48 modules because of the difference in air flow per wet module. A design giving nearly the same incremental cost at a lower fan power could have been obtained at 2250 acre-ft by fixing the number of wet modules at 30, for example, the average of the 1200-acre-ft and 400-acre-ft values. The water-to-air ratios were such that tower constants ranged from 0.56 to 1.26. Approaches on the hottest day ranged from 17.2 to $36.9^{\circ} \mathrm{F}$.

The condenser designs all used very small terminal temperature differences of 1.80 to $2.72^{\circ} \mathrm{F}$. A run made at a TTD of $5.0^{\circ} \mathrm{F}$ at 1200 acre-ft showed a $0.04-\mathrm{mill} / \mathrm{kWh}$ increase in incremental cost (see Table 7). The water range, which was $20.1^{\circ} \mathrm{F}$ for all-dry operation, varied from 33.0 to $37.8^{\circ} \mathrm{F}$ for the wetdry cases. A run made at a fixed range of $25.0^{\circ} \mathrm{F}$ at 1200 acre-ft showed a $0.10-\mathrm{mill} / \mathrm{kWh}$ increase in incremental cost (Table 7).

The maximum turbine back pressure for the wet-dry cases was considerably lower than for the all-dry case, which reduced the driving force for heat transfer. This seems to explain the reason for the decrease in water range with all-dry operation.

Cooling system capital, the largest component of the incremental cost falls from 2.27 to $1.00 \mathrm{mill} / \mathrm{kWh}$ with increasing water availability. The next largest cost is that for auxiliary power scaling, which falls from 0.31 to 0.17 


\section{TABLE 7. Effect of Fixing Design Inputs at $1200 \mathrm{AF}$}

DRY TOWER

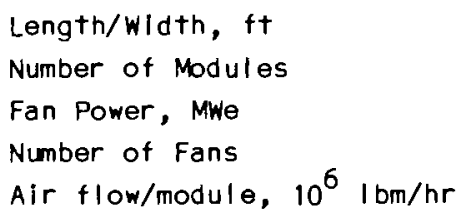

CONDENSER

\begin{tabular}{l} 
Base TTD Fixed Water Velocity Ranged Fixed \\
Case at $5^{\circ} \mathrm{F}$ \\
\hline
\end{tabular}

$\begin{array}{cc}1960 / 143 & 2064 / 143 \\ 57 & 60 \\ 3.73 & 3.70 \\ 171 & 180 \\ 9.59 & 9.41\end{array}$

$1886 / 143$
55
3.88
165
9.81

$1799 / 143$

52

4.44

156

10.5

$\begin{array}{cccc}929 / 56 & 825 / 56 & 856 / 56 & 657 / 56 \\ 27 & 24 & 25 & 19 \\ 0.87 & 1.21 & 0.93 & 1.06 \\ 27 & 24 & 25 & 19 \\ 2.43 & 2.82 & 2.54 & 2.93 \\ 2.05 & 2.16 & 2.10 & 3.65 \\ 1.04 & 1.01 & 1.03 & 0.735 \\ 21.3 & 21.8 & 21.7 & 29.1\end{array}$

$\begin{array}{llll}37.8 & 34.7 & 37.8 & 25.0 \\ 2.16 & 5.00 & 1.96 & 3.20 \\ 0.663 & 0.516 & 0.624 & 0.717\end{array}$

PERFORMANCE PARAMETERS

Optimum Design Temperature, ${ }^{\circ} \mathrm{F}$

Design Turbine Back Pressure, in. Hg

Maximum Turbine Back Pressure, in. Hg

Net Power e Maximum Turbine Back Pressure, Mwe

Pump Power, Mwe
$3.30 \quad 3.23$

$4.85 \quad 4.88$

982.0

9.12

980.6

9.46

COST SUMMARY

Cooling System, mill/kwh

Capacity, mili/kwh

Steam Supply Scaling, mill/kwh

Heat Rate Scaling, mill/kwh

Auxiliary Power Scaling, mill/kwh

Energy, mlll/kwh

Base Fuel, mill/kwh

OSM, mill/kWh

water, mills/kwh

Incremental cost of Cooling, mill/kwh

\begin{tabular}{rrrr}
1.41 & 1.44 & 1.53 & 1.53 \\
0.06 & 0.06 & 0.06 & 0.04 \\
0.06 & 0.06 & 0.06 & 0.06 \\
-0.03 & -0.04 & -0.02 & -0.04 \\
0.20 & 0.21 & 0.15 & 0.28 \\
0.26 & 0.27 & 0.26 & 0.16 \\
0.12 & 0.12 & 0.10 & 0.14 \\
0.08 & 0.08 & 0.09 & 0.09 \\
0.0 & 0.0 & -0.0 & 0.0 \\
\hline 2.15 & 2.19 & 2.22 & 2.25
\end{tabular}


mill/kwh with increasing water. This cost is proportional to the total fan and pump power, which fell only $15 \%$ above 600 acre-ft for the optimums shown. Heat rate scaling, which ranged from $-0.19 \mathrm{mill} / \mathrm{kWh}$ to $+0.08 \mathrm{mill} / \mathrm{kWh}$, is determined by the turbine back pressure at the design temperature. Heat rate scaling is a negative quantity if the turbine back pressure at the design point is less than the 3.5-in. - Hg value at which the turbine is rated and is positive if the turbine back pressure at the design point exceeds $3.5 \mathrm{in}$. $\mathrm{Hg}$.

The cost of providing additional "base fuel" to the power plant to account for plant scaling, for auxiliaries and heat rate and for loss in capacity due to back pressure variations, is nearly constant at 0.10 to $0.15 \mathrm{mill} / \mathrm{kWh}$. The cost of gas turbine energy, however, varies considerably from 0.02 to 0.31 mill/kWh, peaking in the 300 - to 200 -acre-ft range.

Table 7 shows an example of the type of information that can be obtained using the BNW-III code. This table provides information on the effects on incremental cost of holding at fixed values condenser terminal temperature difference, water velocity in the pipes, and water range. The base case was taken from Table 2. The base case TTD was $2.16^{\circ} \mathrm{F}$, which is lower than power plant practice permits. Therefore a run was made at $5.0^{\circ} \mathrm{F}$; the increase in incremental cost was $0.04 \mathrm{mill} / \mathrm{kWh}$. Similarly the base case water velocity was $12 \mathrm{ft} / \mathrm{sec}$, which is higher than water velocities normally used; reducing the water velocity to $7 \mathrm{ft} / \mathrm{sec}$ resulted in an increase in incremental cost of $0.07 \mathrm{mill} / \mathrm{kWh}$. Finally, a run was made at a water range of $25^{\circ} \mathrm{F}$ to obtain some information on how sensitive incremental cost was to water range. Decreasing the water range from $37.8^{\circ} \mathrm{F}$ to $25^{\circ} \mathrm{F}$ resulted in an increase in incremental cost of $0.10 \mathrm{mill} / \mathrm{kWh}$.

Table 8 presents some results which give an idea of the effect of input selection on local optimums and on the different plant designs that result in no significant effects on incremental cost. The two 300-acre-ft runs differ only in that the maximum allowed turbine back pressure was $8.0 \mathrm{in}$. $\mathrm{Hg}$ in one case and $15.0 \mathrm{in.} \mathrm{Hg}$ in the other. The two 2250 -acre-ft runs likewise differ in that the maximum allowed turbine back pressures were $5.5 \mathrm{in}$. $\mathrm{Hg}$ and $8.0 \mathrm{in}$. $\mathrm{Hg}$, respectively. Note that all of maximum turbine back pressures inputted were well above the optimum maximum turbine back pressures in all cases. Thus 
TABLE 8. Effect of a Minor Input Change on Local Optimums

300 acre-ft

INPUT DIFFERENCE

Maximum Al lowed Turbine Back Pressure, in. Hg

DRY TOWER

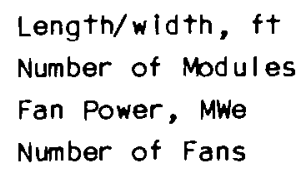

$\begin{array}{llll}8.0 & 15.0 & 5.5 & 8.0\end{array}$

$\begin{array}{cccc}2208 / 143 & 2105 / 143 & 1580 / 143 & 1564 / 143 \\ 64 & 61 & 46 & 46 \\ 5.25 & 4.65 & 2.74 & 2.81 \\ 192 & 183 & 138 & 138 \\ 10.36 & 10.1 & 9.29 & 9.37\end{array}$

$\begin{array}{cccc}621 / 56 & 587 / 56 & 826 / 56 & 826 / 56 \\ 18 & 17 & 24 & 24 \\ 0.13 & 0.11 & 2.12 & 2.23 \\ 18 & 17 & 24 & 24 \\ 1.49 & 1.42 & 3.39 & 3.45 \\ 5.74 & 6.08 & 1.77 & 1.73 \\ 0.56 & 0.54 & 1.14 & 1.15 \\ 36.9 & 38.5 & 19.2 & 18.9\end{array}$

$\begin{array}{llll}33.0 & 34.8 & 35.5 & 35.8 \\ 2.12 & 1.68 & 1.92 & 2.08 \\ 0.713 & 0.739 & 0.697 & 0.676\end{array}$

$\begin{array}{cccc}57.0 & 57.0 & 42.0 & 42.0 \\ 3.29 & 3.63 & 3.93 & 3.93 \\ 6.47 & 7.00 & 4.24 & 4.26 \\ 960.3 & 955.6 & 994.4 & 994.1 \\ 10.56 & 9.86 & 9.11 & 8.99\end{array}$

$\begin{array}{rlll}1.56 & 1.49 & 1.29 & 1.29 \\ 0.13 & 0.15 & 0.02 & 0.02 \\ 0.06 & 0.06 & 0.06 & 0.06 \\ -0.03 & 0.02 & 0.07 & 0.07 \\ 0.25 & 0.23 & 0.19 & 0.19 \\ 0.31 & 0.38 & 0.08 & 0.08 \\ 0.12 & 0.13 & 0.15 & 0.15 \\ 0.09 & 0.08 & 0.07 & 0.07 \\ 0.0 & 0.0 & \frac{0.0}{1.92} & -\frac{0.0}{1.92}\end{array}$


the true optimum design is the same, independent of the change in input conditions. The effects of local optimums can be seen in the 300-acre-ft: increasing the allowed range of turbine back pressures resulted in an increase in the "optimum" incremental cost of $0.04 \mathrm{mill} / \mathrm{kWh}$. This is as much a change as caused by fixing TTD equal to $5^{\circ} \mathrm{F}$ in Table 7. Basically, the code was allowed to choose a wider selection of designs when the allowed turbine back pressure was increased; however the wider choice of allowed designs could lead either to a better or to a poorer (as at 300 acre-ft) local optimum.

The design differences shown in Table 8 are typical for those found in the previous PNL parametric studies, although significantly larger differences in designs were found at essentially constant incremental cost. Notice that though incremental costs were about the same, the number of dry modules was 64 and 61 at 300 acre-ft. The 2250-acre-ft case is somewhat unusual in its lack of variation. It is this ability of the optimization process to come up with a wide variety of designs at nearly the same incremental costs that makes it risky to draw global conclusions from the results on Table 7. 


\section{REFERENCES}

Braun, Daniel J., J. A. Bamberger, David J. Braun, D. W. Faletti and L. E. Wiles. 1978. A User's Manual for the BNW-II Optimization Code for Dry/Wet-Cooled Power Plants-Volume II. PNL-2674 Vol. II, Pacific Northwest Laboratory, Richland, Washington.

Braun, David J., Maniel J. Braun, W. V. DeMier, D. W. Faletti and L. E. Wiles. 1977. A User's Manual for the BNW-I Optimization for DryCooled Power Plants-VoTume II. BNWL-2180, V01. II Pacific Northwest Laboratory, Richland, Washington.

Cooling Tower Institute. 1967. Cooling Tower Performance Curves. Cooling Tower Institute, Houston, Texas.

Dickey, J. B., Jr. 1978. Managing Waste Heat with the Water Cooling Tower. 3rd ed., Marley Cooling Tower Company, Mission, Kansas.

Fryer, B. C., Daniel J. Braun, David J. Braun, L. E. Wiles and D. W. Faletti. 1976. An Engineering and Cost Comparison of Three Different All-Dry Cooling Systems. BNWL-2121, Pacific Northwest Laboratory, Richland, Washington.

Hudson Products Corporation. 1967. General Catalog for Tuf-Lite Fans. Hudson Products Corporation, Houston, Texas. 


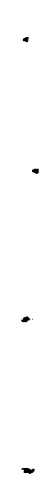

- 
APPENDIX

DRY MODULE DESIGN CRITERIA 
APPENDIX

\section{DRY MODULE DESIGN CRITERIA}

The dry modules are designed to handle the total heat rejection of the power plant at the ambient design temperature. The air flow rate to the dry modules, temperature difference between the water entering and leaving the condenser, and number of dry modules are all independent variables for a given design.

In BNW-III, the steam exhaust temperature must be guessed initially, from which the back pressure of the turbine is calculated. The heat rejection from the power plant is dependent on the turbine back pressure. The water flow rate is calculated from the heat rejected by the plant and the temperature difference allowed for the water.

Heat transfer coefficients for the air side and water side of the heat exchanger are calculated empirically based on the flow rates raised to a power. The overall heat transfer coefficient is calculated using the surface areas and heat transfer coefficients for the air and water sides. The heat capacities of air and water flow are compared, and the smaller is used to determine the number of transfer units in conjunction with air-side surface area and overall heat transfer coefficient.

The ratio of water to air neat capacities and the number of transfer units are used to find the effectiveness of the heat exchanger. The type of heat exchanger, crossflow versus counterflow, and the number of passes ( 1 or 2 for crossflow) also affect the effectiveness of the heat exchanger.

The capacity of the heat exchangers is calculated from the effectiveness of the dry heat exchangers and from the temperature difference between the entering air temperature and entering water temperature.

A comparison is made between the heat rejected by the plant and the heat that can be rejected by the heat exchangers. If the heat rejected by the heat exchangers is less than the heat rejected by the plant, the steam temperature 
is increased and another iteration is made in all the calculations just described. If the heat exchangers can reject more heat than is rejected by the plant, the steam temperature is adjusted until the heat rejection rates match. 
DISTRIBUTION

No. of

Copies

OFFSITE

U.S. Department of Energy

Office of Assistant General

Counsel for Patents

Washington, DC 20545

\section{DOE Technical Information Center}

10 U.S. Department of Energy

I. Helms

High Temperature Gas Reactor NE-540, Germantown

Washington, DC 20545

U.S. Department of Energy W. F. Savage, Acting Director Office of Coordination \& Special Projects, Utility Coordination Washington, DC 20545

U.S. Department of Energy

N. Goldenberg

Director, Division of Advanced

Nuclear Systems and Projects

Washington, DC 20545

U.S. Department of Energy

C. Grua

Environmental Control Technology

Office of Environmental

Compliance Overview

Washington, DC 20545

U.S. Department of Energy

R. Oeh 1

Office of Coordination and

Special Projects,

Utility Coordination

NE-550, Germantown

Washington, DC 20545
No. of

Copies

U.S. Department of Energy

W. E. Mott

Director, Environmental Control

Technology

Office of Environmental

Compliance Overview

Washington, DC 20545

Allied Chemical Company

B. R. Dickey

550 2nd Street

Idaho Falls, ID 83401

Allis-Chalmers Power Systems, Inc. J. S. Joyce

1135 South 70th Street

West Allis, WI 53214

Aluminum Company of America

E. T. Wanderer

Alcoa Technical Center

Alcoa Center, PA 15069

American Electric Power Service Corporation

H. J. Janzon

2 Broadway

New York, NY 10004

American Electric Power Service Corporation

C. Swenson

2 Broadway

New York, NY 10004

Aqua-Chem

R. M. Ahlgren

P.0. Box 421

Mi Twaukee, WI 53201 
No. of

Copies

Arizona Public Service Co.

D. L. Broussard

M.S. 5629

P.0. Box 21666

Phoenix, AZ 85036

Arizona Public Service Co.

$T$. Woods

P.0. Box 21666

Phoenix, AZ 85036

Babcock \& Wilcox

M. W. Peterson

Fossil Power Division

20 South Van Buren

Barberton, OH 44203

Baltimore Aircoil Co., Inc.

R. E. Cates

Mandger, Advanced Engineering

P.0. Box 7322

Baltimore, MD 21227

Baltimore Gas \& Electric Co.

G. C. Creel

Gas \& Electric Building

Baltimore, MD 21203

Battelle-Geneva

J. P. Budliger

7 Route De Drizi

1227 Geneva, SWITZERLAND

Bechtel Corporation

$P$. Leung

P.0. Box 60860

Terminal Annex

Los Angeles, CA 90060

Bechtel Corporation

G. R. Reti

P.0. Box 3965

San Francisco, CA 94119
No. of

Copies

Betz Environmental Engineers

J. Soost

One Plymouth Meeting Mall

Plymouth Meeting, PA 19462

Black, Crow and Eidsness, Inc.

C. G. Thompson

807 South McDonough

Montgomery, AL 35104

Black Hills Power and Light Company

D. Sigdestad

P.0. Box 1400

Rapid City, SD 57701

Boeing Aerospace Division

D. Gilbert (M.S. 2R00)

P.0. Box 3999

Seattle, WA 98124

Bonneville Power Administration

E. H. Hall

1002 N.E. Holladay Street

Box 3621

Portland, OR 97208

Burns and Roe, Inc.

700 Kinder Kamack Road

Oradel, NY 07649

California Energy Commission

C. Webb

15169 th St.

Sacramento, CA 95814

California Energy Commission

L. E. Stamets

15169 th St.

Sacramento, CA 95814

Carolina Power \& Light Co.

J. Sell

336 Fayettesville Street

Raleigh, NC 27602 
No. of

Copies

Catalytic Construction Corp. J. Morse

P.0. Box 15232

Charlotte, NC 28210

Central and Southwest Services

J. C. Wells

2700 One Main Place

Dallas, TX 75250

Ceramic Cooling Tower Co.

P. A. Frohwerk

P.0. Box 425

Forth Worth, TX 76101

Chicago Bridge and Iron Company

M. Husain

800 Jovie Boulevard

Oak Park, IL 60521

Combustion Engineering Lummus Engineering Company

R. J. Croke

1515 Broad St

Bloomingfield, N 07003

Columbus and Southern Ohio Electric Co.

L. W. Meridith

General Manager, Generation Department

215 North Front Street

Columbus, $\mathrm{OH} 43215$

Combustion Engineering

H. H. Osborn

Air Preheater Company

Wellsville, NY 14895

Commonwealth Edison

R. H. Holyoak

One First Plaza

P.0. Box 767

Chicago, IL 60690
No. of

Copies

Consolidated Edison Co. of New York, Inc.

W. A. Messner

4 Irving Place

New York, NY 10003

Consolidated Edison Co. of New York, Inc.

C. L. Newman

4 Irving Place

New York, NY 10003

Cooling System, Inc.

$C$. Mitchel

8490 Avenue 296

Visalia, CA 93877

Cornell University

F. K. Moore

Ithaca, NY 14850

Curtiss-Wright Corporation

R. J. Haberski

One Passaic Street

Wood Ridge, NJ 07075

Dames \& Moore

L. Craton

Suite 1000

$1100 \mathrm{Glendon}$ Avenue

Los Angeles, CA 90024

Delmarva Power \& Light

F. Cook

800 King Street

Wilmington, DE 19801

Dow Chemical Company

$E$. Wagener

2800 Mitchel1 Drive

Walnut Creek, CA 94598

Duke Power Company

S. K. Blackley

P.0. Box 2178

Charlotte, NC 28201 
No. of

Copies

Duquesne Light Co.

J. Latshaw

435 6th Avenue

Pittsburgh, PA 15219

Dynatech Company

E. Guyer

99 Erie Street

Cambridge, MA 02139

Ecodyne

J. Slotnik

607 First Street, S.W.

Massillon, $\mathrm{OH} 44646$

Ecodyne Cooling Products

K. D. Whitehead

P.0. Box 1267

Santa Rosa, CA 95403

Electric Power Research Institute J. Maulbetsch

3412 Hilview Avenue

P.0. Box 10412

Palo Alto, CA 94304

Electric Power Research Institute

J. A. Bartz

3412 Hilview Avenue

P.0. Box 10412

Palo Alto, CA 94304

El Paso Electric Co.

D. G. Isbell

P.0. Box 982

El Paso, TX 79999

Empire State Electric Energy Research Corp.

L. Geller

1271 Avenue of the Americas

New York, NY 10020

Environmental Protection Agency

T. G. Brna (MD-61)

IERL/RTP

Research Triangle Park, NC 27711
No. of

Copies

Environmental Protection Agency

A. Galley (WH-552)

401 M. Street SW

Washington, DC 20460

Environmental Protection Agency

M. Maxwell (MD-61)

IERL/RTP

Research Triangle Park, NC 27711

Environmental Sciences and Services

W. G. Hoydysh

150 East 73rd Street

New York, NY 10021

Environmental Systems Corporation

K. R. Wilber

200 Tech Center Drive

Knoxville, TN 37912

ERG Incorporated

G. M. Benson

Lowell 57th Street

Oakland, CA 94608

Exxon Research Center

J. G. Stevens

B1dg. 1, Rm. 2048

P.0. Box 8

Linden, NJ 07036

Federal Power Commission

E. Sligh

825 N. Capitol Street

Washington, DC 20426

Florida Power \& Light Co.

$C$. Henderson

9250 W. Flagler Street

Miami, FL 33174 
No. of

Copies

Foster Wheeler Development Corporation

R. J. Zoschak

Technical Director, Applied

Thermodynamics Research

12 Peach Tree Hill Road

Livingston, NJ 07039

Foster Wheeler Energy Corporation

E. L. Damon

110 S. Orange Avenue

Livingston, NJ 07039

Foster Wheeler Energy Corporation

W. H. Fisher, Jr.

Project Manager

110 S. Orange Avenue

Livingston, NJ 07039

Franklin Institute Research

Laboratories

G. P. Wachtell

Twentieth Parkway

Philadelphia, PA 19103

Frick Company

J. Bibroff

15302 El Mar Lane

Kerman, CA 93630

GEA Power Cooling Systems, Inc.

G. Hesse

P.0. Box 81608

San Diego, CA 92138

General Atomic Company

H. P. Fay

P.0. Box 81608

San Diego, CA 92138

General Electric Co.

E. H. Miller

Large Steam Turbine Division

300 Nott Street

Schenectady, NY 12301
No. of

Copies

General Motors Corp.

R. K. Shah

Harrison Radiator Division

Lockport, NY 14094

Georgia Power Co.

T. E. Byerley

P.0. Box 4545

Atlanta, GA 30302

Heat Transfer Research Inc.

J. E. Taborek

1000 S. Fremont Avenue

Alhambra, CA 91802

Hudson Products

M. W. Larinoff

6855 Horwin Drive

Houston, TX 77036

Hudson Products

E. C. Smith

6855 Horwin Drive

P.0. Box 36100

Houston, TX 77036

Ingersol 1-Rand

W. R. Scott, Jr.

Phillipsburg, NJ 08865

Ital impianti-Societa Italiana Impianti p.a.

C. Rocco

Piazza, Piccapietra 9

18121 Genoe, ITALY

Los Alamos Scientific Laboratory

D. Abbey

S-2, MS 606

Los Alamos, NM 87545

Los Angeles Department of Water and Power

Peter Lowery

111 N. Hope Street

Los Angeles, CA 90012 
No. of

Copies

Louisiana Power \& Light Co. D. L. Aswell

142 Delaronde Street

New Orleans, LA 70174

The Charles T. Main Co.

E. S. Miliaras

Southeast Tower

Prudential Center

Boston, MA 02199

The Marley Company

C. A. Baird

12 S. 12th Street

Philadalphia, PA 19107

The Marley Company

J. D. Holmberg

5800 Fox Ridge Drive

Mission, KS 66202

The Marley Company

R. Landon

5800 Fox Ridge Drive

Mission, KS 66202

Martin Marietta Laboratories

$L$. Bongers

1450 South Rolling Road

Baltimore, MD 21227

Massachusetts Institute of Technology

L. R. Glicksman

77 Massachusetts Avenue

Cambridge, MA 02139

Massachusetts Institute of Technology

M. W. Golay

77 Massachusetts Avenue

Cambridge, MA 02139
No. of

Copies

Massachusetts Institute of Technology

R. Harleman

Department of Civil Engineering

77 Massachusetts Avenue

Cambridge, MA 02139

MCDonnel1 Douglas Astronautics Company

W. H. P. Drummond

5301 Balsa Avenue

Huntington Beach, CA 92647

Minnesota Power Cooperative, Inc.

L. A. Hillier

Box 1318

Grand Forks, ND 58201

R. D. Mitchell

Consulting Engineer

4531 East Best Road, SEDC

Larkspur, CO 80118

Montana Power Co.

$R$. Hofacher

40 E. Broadway

Butte, MT 59701

Niagara Blower

W. Kals

405 Lexington Avenue

New York, NY 10017

Northeast Utilities

R. H. Meyer

P.0. Box 270

Hartford, CT 06101

Northern States Power Co.

R. Stansfield

414 Nicollet Mall

Minneapolis, MN 55401 
No. of

Copies

Dak Ridge National Laboratory

J. W. Michel

OTEC Heat Exchange Project

Box Y

Oak Ridge, TN 37830

Orange \& Rockland Utilities, Inc.

R. H. Metzger

75 West Route 59

Spring Valley, NJ 10977

Oregon State University

L. P. Davis

Department of Mechanical

Engineering

Corvallis, OR 97330

Oregon State University

C. E. Wicks

Departinent of Chemical

Engineering

Corvallis, OR 97330

Oregon State University

J. G. Knudson

Engineering Experiment Station

Corvallis, OR 97330

Pacific Gas \& Electric

A. A. Ariey

77 Beale Street

San Francisco, CA 94106

Pacific Gas \& Electric

R. E. Price

77 Beale Street

San Francisco, CA 94106

Pacific Power \& Light Co.

W. C. Bruaer

Public Service Bldg.

Portland, OR 97204

Pennsylvania Power \& Light

W. Dussinger

2 North Ninth Street

Allentown, PA 18101
No. of

Copies

Pennsylvania Power \& Light

H. G. Pfeiffer

2 North Ninth Street

Allentown, PA 18101

PFR Engineering Systems, Inc.

T. Rozenmann, President

Suite 832

4676 Admiralty Way

Marina del Rey, CA 90291

Philadelphia Electric Co.

J. Allen

2301 Market Street

Philadelphia, PA 19101

Prof. Ing. Carlo Roma

Piazza delle Muse 8

Rome, ITALY

Pickard Low \& Garrick

L. Rust

120018 th St. NW

Suite 612

Washington, DC 20036

Power Generation Cooling Systems

G. L. Henderson

4714-52nd Street S.

Seattle, WA 98118

Public Service of Colorado

R. F. Walker

5900 E. 39th Avenue

Denver, CO 80207

Public Service Company of Indiana

S. W. Shields

100 East Main Street

Plainfield, IN 46168

Public Service Company of New Mexico

C. D. Bedford

P.0. Box 2267

Albuquerque, NM 87103 
No. of

Copies

Public Service Company of New Mexico

D. J. Jroves

P.0. Box 2267

Albuquerque, NM 87103

Radian Corporation

F. B. Mesich

P.0. Box 9948

Austin, TX 78766

Reynolds Metal Company

J. R. Scott

P. 0. Box 27003

Richmond, VA 23261

Richmond Field Station

H. H. Sephton

47th and Hoffman Blvd.

Richmond, CA 94804

Salt River Project

S. M. Chalmers

P.0. Box 1980

Phoenix, AZ 85001

San Diego Gas \& Electric

R. G. Lacy

101 Ash Street

San Diego, CA 92107

Seattle City Light

R. G. Sheehan

1015 Third Avenue

Seattle, WA 98104

Southern California Edison

D. M. Burkhart

2244 Walnut Grove Avenue

Rosemead, CA 91770

Southern California Edison

F. A. McCracken

2244 Walnut Grove Avenue

Rosemead, CA 91770
No. of

Copies

Southern Services, Inc.

C. H. Goodman

P.0. Box 2625

Birmingham, AL 35202

Southwestern Public Service Co. W. R. Esler

SPS Tower

6th at Tyler

Amarillo, TX 79170

Stanford University

A. L. London

Department of Mechanical

Engineering

Stanford, CA 94305

Stearns-Rogers, Inc.

J. Y. Parce

Box 5888

Denver, C0 80217

Stewart-Warner Corporation

South Wind Division

V. N. Tramontini

1514 Dover Street

Indianapolis, IN 46221

Stone \& Webster Engineering Corporation

D. H. Guild

225 Franklin Street

Boston, MA 02107

Tampa Electric Co.

H. I. Wilson

P.0. Box 111

Tampa, FL 33601

Tennessee Valley Authority

Energy Research

R. D. Boroughs

1345 Commerce Union Bank Bldg.

Chattanooga, TN 37401 
No. of

\section{Copies}

Tennessee Valley Authority

H. B. Flora, II I

1320 Commerce Union Bank Bldg.

Chattanooga, TN 37401

Texas Electric Service Co. W. Keel

115 W. Seventh Street

Fort Worth, TX 76102

Texas Power \& Light Co.

Gerson Berman

P.0. Box 226331

Dallas, TX 75266

Tucson Gas \& Electric

A. A. Ward

220 W. 6th Street

Tucson, AZ 85701

Union Carbide Corp.

H. D. Fricke

Linde Division

61 East Park Drive

Tonawanda, NY 14150

Union Carbide Corp.

L. R. Niendorf

Linde Division

61 East Park Drive

Tonawanda, NY 14150

Union Carbide Corp.

J. M. Vance

ORGDP - K-25

P.0. Box P, Mail Stop 387

Oak Ridge, TN 37803

United Engineers \& Constructors

M. Hu

30 S. 17th Street

Philadelphia, PA 19103
No. of

Copies

University of Bremen

K. Simhan

Bremen, WEST GERMANY

University of Iowa

J. F. Kennedy

Hydraulic Research Institute

Iowa City, IA 52240

University of Kentucky

T. E. Eaton

Mechanical Engineering

Departiment

Lexington, KY 40506

University of South Florida

A. D. Craus

College of Engineering

Tampa, FL 33620

United States Steel Corp.

T. L. Myron

Research Laboratory

Monroeville, PA 15146

Utah Power \& Light

M. W. Russon

P.0. Box 899

Salt Lake City, UT 84110

Utah Power \& Light

Frank M. Davis

1407 W. N. Temple

Salt Lake City, UT 84110

Utah Power \& Light

V. A. Finlayson

1407 W. N. Temple

Salt Lake City, UT 84110

Vermont Yankee Nuclear Power

E. Gaines, Jr.

77 Grove Street

Rutland, VT 05701 
No. of

Copies

Virginia Electric \& Power Co. S. Ragone

700 E. Frankl in Street

Richmond, VA 23261

Washington Public Power

Supply System

J. Chasse

P.0. Box 968

300 George Washington Way

Richland, WA 99352

Washington State University

R. W. Crain, Jr.

Department of Mechanical

Engineering

Pullman, WA 99164

Washington Water Power Co.

D. L. 01 son

E. 1411 Mission Avenue

Spokane, WA 99202

Water Purification Associates

H. Gold

238 Main Street

Cambridge, MA 02142

Western States Water Council

J. A. Barnett

Executive Director

220 South 2nd East

Suite 200

Salt Lake City, UT 84111

Westinghouse Electric Corp.

R. F. Boyle

Power Generation Systems

Engineering

700 Braddock Avenue Room 9L51

East Pittsburgh, PA 15112

Westinghouse Electric Corp.

G. J. Silvestri

Steam Turbines Division - G108

Lester Branch

Box 9175

Philadelphia, PA 19113
No. of

Copies

Westinghouse Electric Corp.

K. A. Oleson

Steam Turbines Division - G108

Lester Branch

Box 9175

Philadelphia, PA 19113

William M. Rice University

W. G. Characklis

Environmental Science and

Engineering

Houston, TX 77001

ONSITE

DOE Richland Operations Office Energy Programs Division

H. E. Ransom

Westinghouse Hanford Company

Hanford Engineering Development Laboratory

J. C. Sonnichsen

29 Pacific Northwest Laboratory

R. T. Al lemann

J. A. Bamberger

D. W. Faletti

J. J. Hauth

D. K. Kreid

R. P. Marshall

S. W. Matsumoto

A. M. Sutey

D. S. Trent

E. V. Werry

K. R. Wheeler

F. R. Zaloudek

File - B. M. Johnson (10)

Technical Information (5)

Publishing Coordination YO(2) 